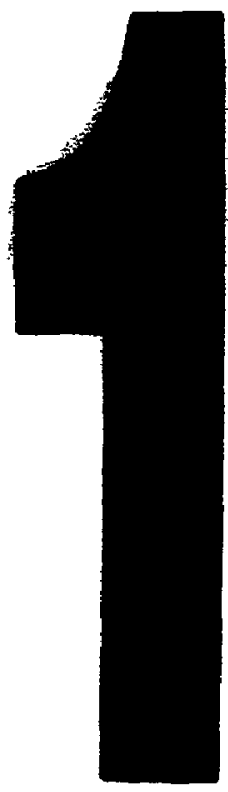

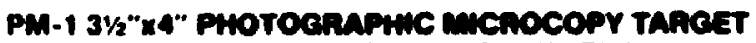

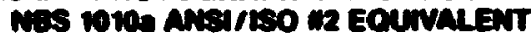

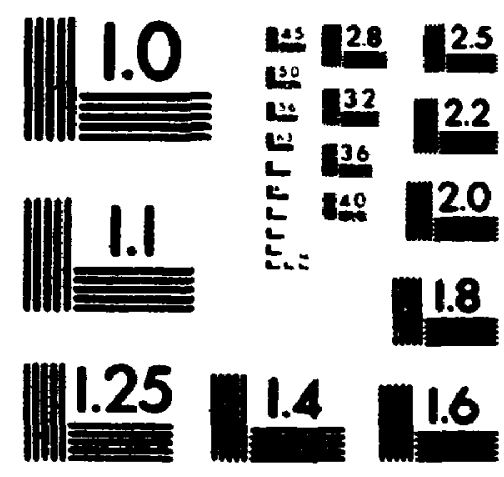


National Library

of Canada

Acquisitions and

Bibliographic Senvices Branch

395 Wellungton Street

Otawa. Ontano

KiA ONu
Bibliotheque nationale

du Canada

Direction des acquisition, et

des services bibliographiques

395. rue Wettington

Ottawa (Omano)

KIA ON4
NOTICE

The quality of this microform is hoavily dependent upon the quallyy of the original thesis submitted for microfilming. Every effort has been made to ensure the highest quality of reproduction possible.

If pages are missing, contact the university which granted the degree.

Some pages may have indistinct print especially if the original pages were typed with a poor typewriter ribbon or if the university sent us an inferior photocopy.
La qualité de cette microforme dépend grandement de la quallub de la thèse soum'se au microfilmage. Nous avons tout fait pour assurer une qualité supérieure de reproduction.

S'il manque des pages, veuillez communiquer avec l'université qui a conféré le grade.

La qualité d'impression de certaines pages peut laisser à désirer, surtout si les pages originales ont été dactylographiées à l'aide d'un ruban usé ou si l'université nous a fait parvenir une photocopie de qualité inférieure.

La reproduction, même partielle, de cette microforme est soumise à la Loi canadienne sur le droit d'auteur, SRC 1970, c. C-30, ot ses amendements subséquents.
Reproduction in full or in part of this microform is governed by the Canadian Copyright Act, R.S.C. 1970, c. C-30, and subsequent amendments.
AVIS 


\title{
THE EFFECTS OF FOREST FRAGMENTATION ON THE POPULATION GENETICS OF ACER SACCHARUM MARSH. (SUGAR MAPLE)
}

\author{
ANDREW G. YOUNG, B.Sc., M.Sc.
A thesis submitted to
the Faculty of Graduate Studies and Research
in partial fulfilment of
the requirements for the degree of

Doctor of Philosophy
Department of Biology
Carleton University
Ottawa, Ontario
12 February 1993

copyright

199.3. Andrew G. Young 
Notional Library

of Canada

Acquisitions and

Bibliographic Services Branch

395 Wwingeron Street

Oitrua Ortano

KiA ONA
Bibliothdque nationale

du Canada

Direction des acquisitions ef

des services bibliographiques

395. ne Wellington

Ottawa (Ontario)

KIA ONA
The author has granted an irruvocable non-exclustre licence allowing the National Library of Canada to reproduce, loan, clideribute or sell coples of hls/her theals by any means and in any form or format, making this thesis available to interested porsons.
L'auteur a accordé une licence irrtvocable ef non exclusive permettant a la Bibliothdque nationale du Canada de reproduire, prôter, distribuer ou vendre des copies de sa thdse de quelque manière et sous quelque forme que ce soit pour mettre des exemplaires de cette these a la disposition des personnes intéressées.

L'auteur conserve la propriété du droit d'auteur qui protege sa th'se. Ni la these ni des extraits substantiels de celle-ci ne doivent être imprimés ou autrement reproduits sans son autorisation.
The author retains ownership of the copyright in his/her thesis. Neither the thesis nor substantial oxtracts from it may be printed or otherwise reproduced without his/her permission.

ISBN 0-3:5-84033-1

\section{Canadầ}


The undersigned hereby recommend to the Faculty of Graduate Studies and Research acceptance of the thesis,

"The Effects of Forest Fragmentation on the Population Genetics of Acer saccharum Marsh. (sugar maple)"

submitted by

ANDREW G. YOUNG, B.Sc., M.Sc.

in partial fulfilment of the requirements for the degree of Doctor of Philosophy

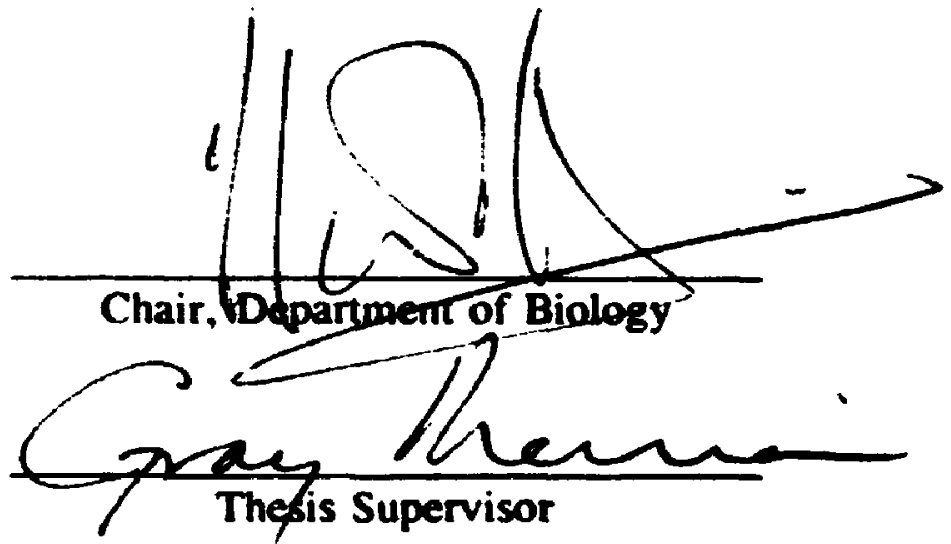

Picyer trocertis

External Examiner

Carleton University 
'A lot of questions. Number One .... damned few answers'

J. - L. Picard 


\begin{abstract}
To examine the population genetic effects of forest fragmentation, genetic (allozyme) variation was cornpared between small (1.4-6.3ha) forest patch (patch) populations and continuous forest (control) populations of the tree Acer saccharum Marsh. (Aceraceae) (sugar maple).
\end{abstract}

Genetic variation of first-year seedling cohorts was compared between eight patch and control populations. In total, the eight patches had six less alleles than the controls, possibly as a result of founder effects when forest fragmentation occurred. However, average levels of genetic variation within patch individuals and populations $\left(H_{1}, P\right)$ were higher than in controls. The distribution of several alleles, and data on wind dispersal of pollen across pasture separating forest patches, suggest that this may be the result of increased inter-population gene flow.

Spatial genetic structures of first-year seedling cohorts were compared between four patch and control populations. Patches exhibited less spatial mixing of genotypes than controls at the smallest scale examined $(10-14.1 \mathrm{~m})$, possibly as a result of reduced overlap of seed shadows in patches, which had lower densities of reproductive individuals. Patches exhibited increased spatial mixing of genotypes at the largest scale examined $(113.1-141.4 \mathrm{~m})$, probably resulting from the incorporation of immigrant pollen pools into mating events at patch edges.

Within a single patch and control population, genetic variation and spatial genetic structure were examined in fo :r cohorts ranging from first-year seedlings to 
reproductive individuals. Control cohorts were genetically very similar. suggesting that processes determining genetic variation and structure operate prior to the inception of the first-year seedling cohort - the m-ljor process is probably mating. There were significant differences in genetic variation among patch population cohorts, which may be the result of disruption of mating relationships.

Overall, results suggest that, apart from a relatively small overall loss of genetic variation within the fragmented forest svstem (patch populations) as a whole. the fundamental genetic effect of forest fragmentation for $A$. sacchartum has been a change in patterns of gene flow among, and possibly, within populations.

Finally, genetic variation and structure were examined at three spatial scales from among individuals to among populations across the species range in Canada. Genetic structure was observed at all of these scales. In light of this, and the observed effects of forest fragmentation at the lower two spatial scales, genetic conservation strategies for this species should aim to maintain the genetic juxtaposition of individuals and populations over a range of scales. 


\section{ACKNOWLEDGEMENTS}

I would first like to thank Dr H. Gray Merriam, my supervisor, and Dr Suzanne Warwick, for their encouragement and advice throughout the course of this project. My sincere thanks also go to the 'third man' on my advisory committee Dr Hans Damman, who always managed to provide a fresh perspective on my research. Dave Omond helped enormously with the extensive field work for this project and, along with Hank, Art and Eddie, grew and cared for the 'maple forest'. Thanks go to Dr Peggy Knowles and Dan Perry of the Department of Forestry at Lakehead University, for initial help with allozyme techniques for sugar maple. Lynn Black provided a great deal of assistance with the allozyme analyses. I thank Drs George Carmody and Lenore Fahrig for discussions on various aspects of this research. Dr Tim Boyle provided regular and much needed discussions on the population genetics of trees and on rugby, not necessarily in order of importance, and my friend Paul Newman provided discussions on everything else! For general advice, whether I wanted it or not, I thank Marc-Andre Villard, John Wegner, Phil Taylor, Kringen Henein and Ron Fritz.

Parks Canada generously allowed sampling to be conducted in the eight National Parks, and the National Capital Commission of Canada gave their permission for the extensive collection of seedlings from Gatineau Park, Quebec. Thanks also 80 to the owners of the woodlots in which sampling was conducted. Financial support for this project was provided by the Natural Sciences and Engineering Research 
Council of Canada (operating grant to Dr H.G. Merriam) and by Parks Canada (contracts to Dr S.I. Warwick and A. Young). I undertook this research while receiving a Carleton University International Student Fee Waiver Scholarship. Dr Sw zanne Warwick generously provided the use of laboratory facilities in the Biosystematics Research Centre of Agriculture Canada.

Finally. I thank my family for their constant encouragement, but most of all I thank my wife, Raewyn, for coming to Canada with me, for enjoying the cold, for collecring maple seedlings all summer and for putting up with me and my work. 
Acceptance sheet

Forethought

Abstract

Acknowledgements

iv

Table of Contents

List of Tables

List of Figures

List of Appendices

GENERAL INTRODUCTION

CHAPTER 1: The effects of forest fragmentation on genetic variation

Introduction

Methods

Results

Discussion

CHAPTER 2: The effects of forest fragmentation on spatial genetic structure

Introduction

Methods

Results

Discussion

CHAPTER 3: The effects of forest fragmentation on genetic variation and spatial genetic structure among cohorts

Introduction

Methods

Discussion 
Table of contents (continued)

Page

CHAPTER 4: Genetic variation and structure at three spatial scales and the implications for conservation

Introduction

Methods

66

Results

71

Discussion

GENERAL DISCUSSION

84

APPENDICES

89

REFERENCES

106 


\section{LIST OF TABLES}

Page

Table 1.1 Electrophoresis buffer systems and enzymes

Table 1.2 Genetic variation and mating system summary statistics

for A. saccharum patch and control populations

Table 1.3 Mean Nei's minimum genetic distances $\left(D_{m}\right)$ among

A. saccharum patch and control populations

Table 1.4 Patch areas, densities of reproductive individuals (inds) and estimates of reproductive population size for A. saccharum patch populations

Table 2.1 Areas and densities of reproductive individuals (inds) for

A. saccharum control and patch populations

Table 2.2 Clark-Evans ratios $\left(r_{A} / r_{\mathrm{E}}\right)$ for low frequency $(p<0.1)$

alleles for $A$. saccharum control and patch populations

Table 3.1 Genetic variation and mating system summary statistics for four cohorts of $A$. saccharum control population ' $A$ ' and patch population ' $a$ '

Table 3.2 Clark-Evans ratios $\left(r_{A} / r_{E}\right)$ for low frequency $(p<0.1)$ alleles for four cohorts of $A$. saccharum control population ' $A$ ' and patch population ' $\mathrm{a}$ '

Table 4.1 Locations of nine regional and eight local populations of

\section{A. saccharum}

Table 4.2 Genetic variation summary statistics for $A$. saccharum regional and local populations

Table 4.3 Genetic differentiation and gene flow summary statistics for $A$. saccharum regional and local populations 


\section{LIST OF FIG L RES}

Pinge

Figure 1.1 Locations of A. sachurum patch and control populations 8

Figure 1.2 Pollen rain around A. succhurum patch population 'a' 21

Figure 2.1 Spatial correlogram of Moran's / for A. suctharum control $\quad 35$ populations (A-D)

Figure 2.2 Moran's $I$ by distance for 16 alleles for .4 . succhurum control population ' $B$ '

Figure 2.3 Spatial correlogram of Moran s $/$ for A. sccichurum patch 38 populations (a-d)

Figure 2.4 Hypothetical seed shadows around reproductive individuals in A. saccharum control and patch populations

Figure 3.1 Spatial correlogram of Moran's $/$ for four cohorts of Sh A. saccharum control population ' $A$ '

Figure 3.2 Spatial correlogram of Moran's $/$ for four cohorts of 58 A. sacchurum patch population ' $a$ '

Figure 4.1 Locations of $A$. saccharum regional and local pxipulations 68

Figure 4.2 Canonical discriminant analysis of genetic variation for 76 A. saccharum regional and local populations 


\section{LIST OF APPENDICES}

Page

Appendix la Allele frequencies, $G$-tests for allele frequency differences and genetic variation estimates at 17 loci for $A$. saccharum patch populations $(a-h)$

Appendix lb Allele frequencies, $G$-tests for allele frequency differences and genetic variation estimates at 17 loci for $A$. saccharum control populations (A-H)

Appendix 2a Inbreeding coefficients $\left(F_{\mathrm{IS}}\right)$ and fixation coefficients $\left(\boldsymbol{F}_{\mathbf{S T}}\right)$ for $A$. saccharum patch populations $(a-h)$

Appendix $2 \mathrm{~b}$ Inbreeding coefficients $\left(F_{\mathrm{IS}}\right)$ and fixation coefficients $\left(F_{\mathrm{ST}}\right)$ for A. saccharum control populations (A-H)

Appendix 3 Calculations for Moran's / spatial autocorrelation coefficient for nominal data under the randomisation assumption following Cliff \& Ord (1981)

Appendix 4 Calculations for nearest neighbour analysis following Clark \& Evans (1954) and using Donnelly's (1978) corrections for finite populations

Appendix 5 Allele frequencies, $G$-tests for allele frequency differences and genetic variation estimates at 11 loci for four cohorts of $A$. saccharum control population ' $A$ ' and patch population ' $a$ '

Appendix 6 Inbreeding coefficients $\left(F_{i s}\right)$ and fixation coefficients $\left(F_{\mathrm{ST}}\right)$ for four cohorts of $A$. saccharum control population ' $A$ ' and patct. population ' $a$ '

Appendix 7 Allele frequencies, $G$-tests for allele frequency differences and estimates of genetic variation at 17 loci for nine regional populations of $A$. saccharum 
List of appendices (continued)

Appendix 8 Inbreeding coefficients $\left(F_{1 s}\right)$ and tixation coefficients $\left(F_{s 1}\right)$

Appendix 9a Nei's minimum genetic distance $\left(D_{\mathrm{m}}\right)$ below the diagonal and geographic distance above the diagonal for nine regional populations of $A$. saccharum

Appendix 9b Nei's minimum genetic distance $\left(D_{m}\right)$ below diagonal and geographic distance above diagonal for eight local populations of $A$. saccharum 


\section{GENERAL INTRODUCTION}

As a result of human modification of the environment, many natural populations of plants and animals are being modified through habitat reduction and degradation. Such modifications may have significant effects on population genetic processes that can impact on both the short term ecological and longer term evolutionary trajectory of populations and species. For reviews see Frankel \& Soule (1981); Soulé (1986); Soulé (1987).

Information about the effects of population modification on genetic processes and genetic variation has come from several sources. Following the seminal work of Buri (1956) on Drosophila melanogaster, experimental manipulations of populations e.g. Bryant er al. (1986); Polans \& Allard (1989); McCommas \& Bryant (1990), have provided insight into the effects of population bottlenecks and processes such as random genetic drift, both in terms of genetic variation in small isolated populations, and the potential for recovery of genetic variation in such populations when exposed to gene flow.

Mathematical models have been used to assess truly long term (thousands of generations) genetic effects of population modifications such as bottlenecks, and how these may be influenced by population parameters such as growth rate e.g. Nei et al. 1975. Models have also provided predictions about rates of loss of variation through processes such as random genetic drift with changing population size, and the possible effects of interactions with non-stochastic processes such as selection e.g. Lande \& Barrowclough (1987). More recently, Gilpin (1991) has used computer simulations to 
investigate the effects of population size. as well as extinction and recolonisation dynamics, on maintenance of genetic variation (heterozygosity).

However, direct extrapolation from the results of these studies to prediction about genetic consequences of modifying natural populations is problematic for several reasons. Experimental studies have generally been conducted using shortlived organisms, often with non-overlapping generations and, with notable exceptions e.g. Bryant et al. 1986, have been run for only a few generations. Mathematical models and computer simulations have made simplifying assumptions regarding study 'organisms' or other parameters e.g. population size. Furthermore, most models are specifically designed to investigate the effect of a single genetic process. However. natural populations of organisms may be considerably more complex, with long generation times, overlapping generations, sexual and asexual reproduction, variable densities of reproductive individuals, spatial and temporal variation in mating relationships and reproductive output. Furthermore, modification of a population may affect several genetic processes at once e.g. selection and gene flow. Perhaps most importantly though, is that both experimental and modelling approaches have largely ignored the roles of interactions among populations in determining population genetic variation and structure, generaliy by assuming that populations are completely isolated. It may be that among-population interactions are what are most affected by current patterns of habitat degradation (Saunders et al. 1991; Dunning et al. 1992). In this study an alternative approach, direct empirical observation, is used to assess the genetic effects of modification of natural populations owing to habitat 
fragmentation, a form of habitat degradation which, over the past 100-200 years, has affected ecosystems all over the world e.g. forest (Harris 1984), grassland (Lord \& Norton 1990), scrubland (Margules \& Nicholls 1987) and prairie (Wilcove 1987). For a review of the ecological effects of habitat fragmentation see Burgess (1988) and Saunders et al. (1991). Specifically, the effect of forest fragmentation on the population genetics of the tree species Acer saccharum Marsh. (Aceraceac) (sugar maple) was investigated, by comparing amounts and patterns of genetic (allozyme) variation in fragmented forest patch populations to populations in more continuous forest distributed over similar spatial scales. The advantage of this approach is that it incorporates all of the effects of forest fragmentation for a real organism, including the possible affects of changes in interactions among populations. The important assumption underlying this approach is that the existing genetic variation and structure, and the processes underlying these, in the continuous $A$. saccharum populations are representative of variation and processes that existed in the pre-fragmentation forest populations from which extant patch populations are derived.

In Chapters 1 and 2 the effects of fragmentation on genetic variation in populations and individuals and spatial genetic structure are compared between firstyear seedling cohorts of forest patch and continuous forest populations. In Chapter 3, genetic variation and spatial structure in four developmentally based cohorts within a single forest patch and continuous population are compared, to specifically investigate effects of fragmentation on processes with significant temporal dynamics e.g. selection. Finally, in Chapter 4, data on genetic variation and structure at three 
spatial scales: among populations across the species range in Canada. among locat populations within a region and among individuals within populations, are compared. Genetic structure at these scales and the possible underlying processes are discussed in the context of a management plan for $A$. saccharum that might encompass the spatial and population scales necessary to represent species' genetic variation and for the maintenance of population genetic and evolutionary processes. 


\section{Chapter 1: The effects of forest fragmentation on genetic variation}

\section{INTRODUCTION}

Habitat fragmentation has corsiderable potential to rapidly and severely reduce population size and increase population isolation through the reduction of habitat patch area and the separation of habitat patches by areas of different land use. Studies of natural plant populations have shown that population size is an important factor in determining the amount of genetic variation maintained within sexual populations and how it is distribured among individuals. Using allozyme data, Moran \& Hopper (1983), McClenaghan \& Beauchamp (1986), Sampson et al. (1988) and Billington (1991) have shown that small populations exhibit less single locus variation, both within populations and individuals, than larger populations. Polans \& Allard (1989) obtained similar results in an experimental study with ryegrass, in which they manipulated population size to investigate the genetic effects of population bottlenecks. They demonstrated that reduction in population size resulted in reduced single locus allozyme and multilocus quantitative morphological variation. In all of these examples reduced genetic variation in small populations may be attributed to founder effects, increased inbreeding and/or genetic drift.

Recently, Wilcove (1987), Templeton et al. (1990), Billington (1991), and Saunders et al. (1991) have suggested that reduced population size and increased isolation, associated with habitat fragmentation, may cause a reduction in genetic variation in habitat patch populations. This may directly affect the short term 
ecological success of patch populations through inbreeding depression. It may also influence the evolutionary potential of populations and species, if genetic variation is reduced so much that populations can no longer respond to changing environments through selection. It is also possible that increased isolation, resulting from habitat fragmentation, may lead to increased genetic differentiation among habitat patch populations.

The objective of this study was to investigate the effects of habitat fragmentation, in this case forest fragmentation, on genetic variation in Acer saccharum populations. Specifically. the hypotheses that forest patch populations of A. saccharum have less genetic variation than more continuous forest populations. owing to founder effects, increased genetic drift and/or inbreeding, and that patch populations are more genetically differentiated, because of increased isolation, were tested.

\section{METHODS}

\section{Study Species}

Acer saccharum (Aceraceae) is a common tree throughout the deciduous forests of southeastern Canada and the northeastern United States of America, occurring naturally in large populations. In Canada its range extends from the southern tip of Lake Erie to northwest of Lake Superior, and northeast as far as the Gaspé Peninsula on the Atlantic coast of Québec and east to Nova Scotia. The southern range limit of A. saccharum is Arkansas and Georgia in the United States (Scoggan 1978), except 
for some populations in the Chios mountains of west Texas and in northern Mexico. It is shade tolerant (Logan 1965; Forcier 1973), capable of sustained population regeneration (Nigh et al. 1985) and may live for 200-300 years (Ledig \& Korbobo 1983). Acer saccharum maintains no seed bank (Marquis 1975). Plants may reach reproductive maturity as early as 40 years of age (Westman 1968). Acer saccharum is monoecious and self-compatible, though seed set from selfed flowers is poor (Gabriel 1967) and selfing is restricted by incomplete dichogamy (Gabriel 1968). Although both insect and wind pollinated, experimental data suggest that wind may be the primary pollen vector (Gabriel \& Garrett 1984). Seeds are wind-dispersed samaras. The species is diploid $(2 n=26)$ throughout its geographic range (Kriebel 1957). Allozyme studies of $A$. saccharum in northwestern Ontario suggest that levels of genetic variation are within expectations for a primarily outbreeding angiosperm tree, and that A. saccharum exhibits both inter-population and intra-population genetic structure (Perry \& Knowles 1989; Perry \& Knowles 1991).

\section{Experimental Design and Study Populations}

To assess the effects of forest fragmentation, genetic (allozyme) variation in eight A. saccharum populations, in fragmented forest patches, was compared to variation in eight control populations, within relatively continuous $A$. saccharum dominated forest.

Forest patch populations (patches) were located around North Gower and Manotick, south of Ottawa, in eastern Ontario, Canada: $45^{\circ} 10.4^{\circ} \mathrm{N}, 75^{\circ} 40.6^{\prime} \mathrm{W}$ (Fig. 1.1). Patches were 1.4-6.3ha (Table 1.4) and were part of a mosaic of forest patches 


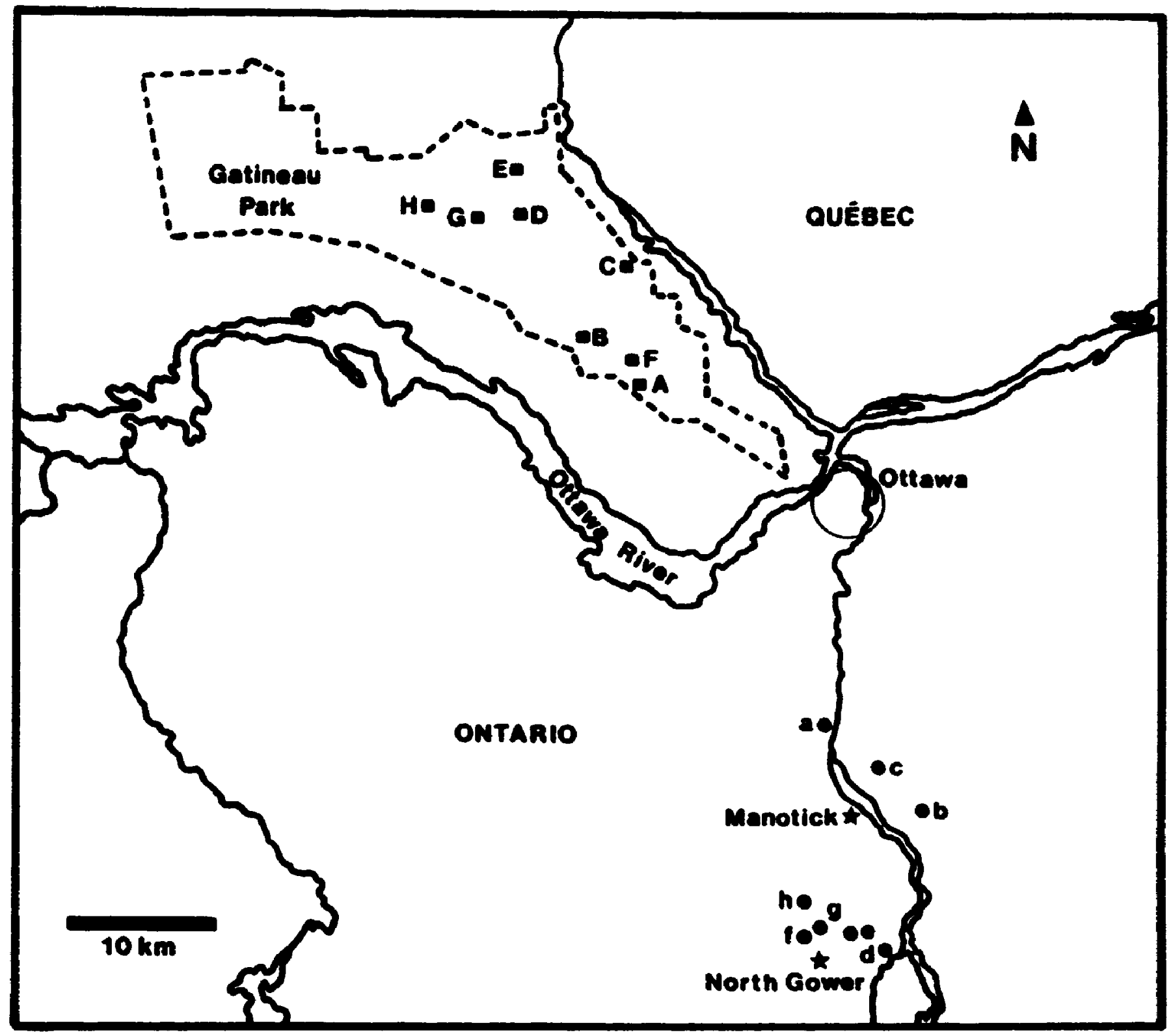

Figure 1.1 Locations of eight forest patch $(a-h)$ and eight control $D(A-H)$ populatuons of A. seccharum. 
separated by intervening agricultural land. Forest patches were created 100-200 years ago when the forest in this area was cleared for crops and pasture (Middleton 1982). Each patch population was at least $400 \mathrm{~m}$ from the nearest $A$. saccharum population and patches were spread over a total area of approximately $400 \mathrm{~km}^{2}$, which encompassed many other similar forest patches containing A. saccharum. All eight forest patches showed evidence of human disturbance in the form of tree cutting. Control populations (controls) were population samples located within extensive A. succharum dominated forest in Gatineau Park, Québec: $45^{\circ} 35.0^{\prime} \mathrm{N}, 75^{\circ} 55.4^{\prime} \mathrm{W}$ (Fig. 1.1), 50km north of the patch populations. Controls were also spread over approximately $400 \mathrm{~km}^{2}$. Within patch and control forest, $A$. saccharum was primarily associated with Fagus grandifolia Ehrh. (beech) and Tilia americana L. (basswood). Forest patches also had a significant Fraximus americana $L$. (white ash) component and some of the control forest contained Quercus rubra L. (red oak).

\section{Sampling and Genetic Data}

Genetic variation was assayed in the first-year seedlings of each of the 16 populations. This is the generation in which any genetic changes that have occurred since forest fragmentation, owing to changes in processes such as genetic drift and inbreeding, should be most obvious. Within each population 50 seedlings were sampled randomly from a tha square quadrat using an $11 \times 11 \mathrm{~m}$ sampling grid, with $10 \mathrm{~m}$ intervals between nearest possible sampling points. Seedlings were removed intact, transplanted into pots, and maintained in a greenhouse for the duration of the study. 
Horizontal starch gel electrophoresis was used to obtain allozyme data for all seedlings. Mature leaf tissue $\left(1.5-2 \mathrm{~cm}^{2}\right)$ was removed from each plant and freshly ground ( $<5$ hours) in a mortar and pestle at $4^{\circ} \mathrm{C}$. in $1.5 \mathrm{ml}$ of extraction buffier: $2 \%$ tergitol 15-S-9, $2 \%$ polyethyleneglycol 20M, 8\% polyvinylpyrrolidone $7: 1$ 40M:360M, 50mM ascorbic acid, 0.4mM nicotinamide adenine dinucleotide, $0.1 \%$ bovine serum albumin, $0.2 \mathrm{mM}$ pyridoxal $5^{\circ}$-phosphate, $0.3 \mathrm{M}$ sucrose, $12 \mathrm{mM}$ cysteine-HCl. 0.66ml B-mercaptoethanol (Cheliak \& Pitel 1984). Samples were frozen in $2 \mathrm{ml}$ microcentrifuge tubes at $-80^{\circ} \mathrm{C}$ until electrophoresis. Frozen samples were thawed to an icy slurry and absorbed onto $3 \times 14 \mathrm{~mm}$ filter paper wicks for introduction into starch gels. Starch gels were $10.5 \% \mathrm{w} / \mathrm{v}$ and $\mathrm{Icm}$ thick. Four gel/electrode buffer systems, ranging from pH5.7 to pH8.8, were used (Table 1.1). Gels were run until a bromophenol blue marker had migrated $1 \mathrm{~cm}$. Wicks were removed and gels were then run until the marker reached $10 \mathrm{~cm}(3.5-6.5$ hours). All gels were run at constant current (Table 1.1 ) at $4^{\circ} \mathrm{C}$. Gels were sliced horizontally into $2 \mathrm{~mm}$ slices and stained for enzymes following Weeden \& Wendel (1989).

Seventeen putative allozyme loci for nine enzymes were resolved clearly and consistently (Table 1.1). These were: alcohol dehydrogenase (ADH) E.C. 1.1.1.1 (1 locus), aspartate aminotransferase (AAT) E.C. 2.6.1.1 (1 locus), fructose-biphosphate aldolase (FBA) E.C. 4.1.2.13 (1 locus), glucose-6-phosphate isomerise (GPI) E.C. 5.3.1.9 (2 loci), glyceraldehyde-3-phosphate dehydrogenase (GAPDH) E.C. 1.2.1.12 (2 loci), malate dehydrogenase (MDH) E.C. 1.1.1.37 (NAD) (2 loci), malate dehydrogenase (MDHP) E.C. 1.1.1.40 (NADP) (2 loci), phosphoglucomutase (PGM) 


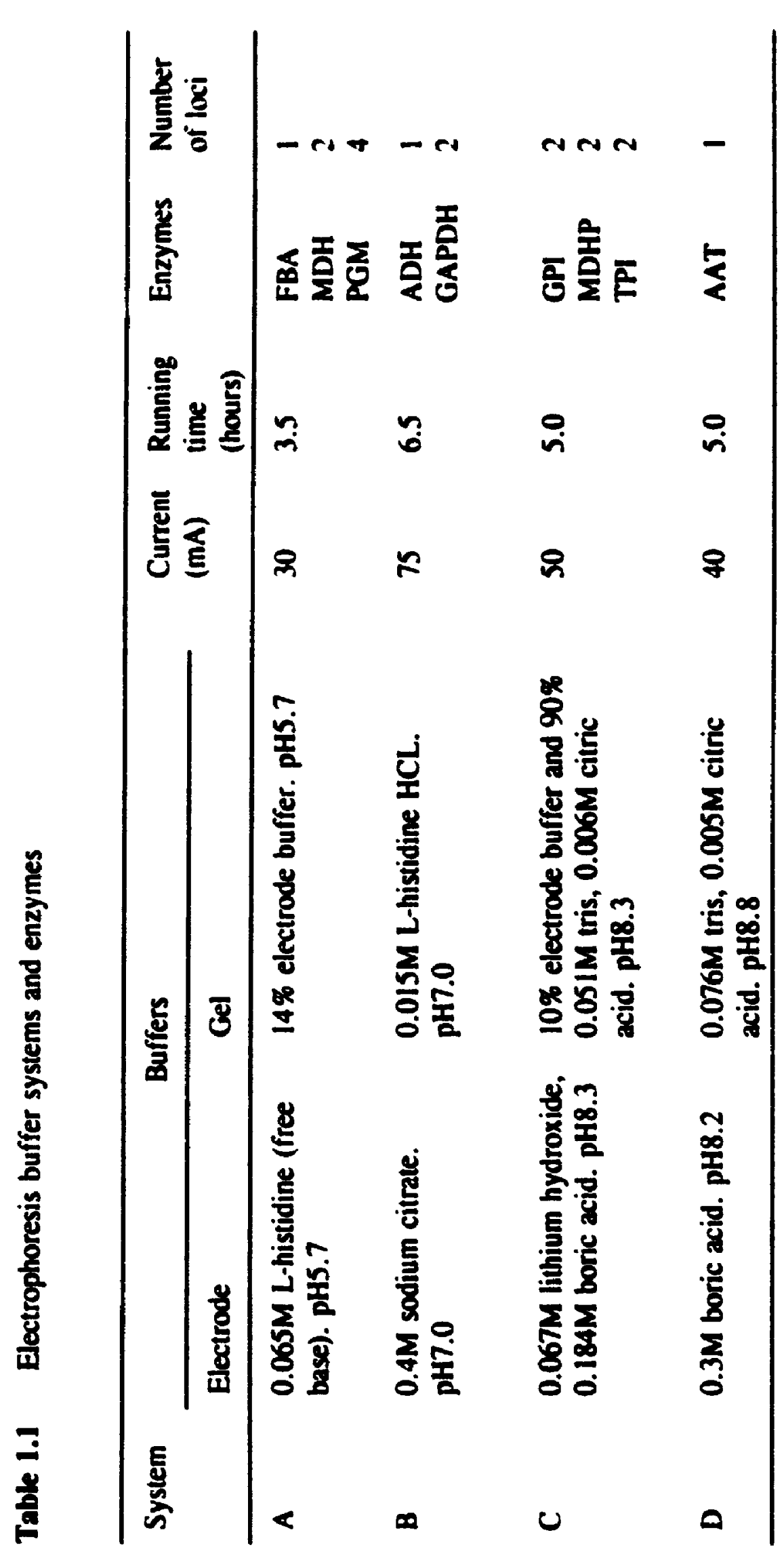


E.C. 5.4.2.2 (4 loci) and triose-phosphate isomirase (TPI) E.C. 5.3.1.1 (2 l(wi). When there were several loci for a single enzyme they were numbered in decreasing order of anodal mobility. Alieles at a locus were identified by their mobility relative to the migration of the bromophenol blue marker $\left(R_{t}\right)$. Phosphoglucomutase exhibited four loci rather than the more usual two (Weeden \& Wendel 1989). Alleles P.gm-1: 0.375, 0.320 and Pgm-4: 0.205 were excluded from the data analysis. These alleles overlapped alleles from $P g m-2$ and $P g m-3$ respectively so that, given the enzyme's monomeric structure, heterozygotes involving these alleles had to be identilied by relative band intensity and this proved unsatisfactory. Mendelian inheritance of Fha-1, Aat-2, Gpi-2 and Mdh-1 has been verified for A. saccharum by Lelliot (1987). It was assumed for the other polymorphic loci, based on concordance between observed and expected banding patterns of putative heterozygotes, given previously suggested enzyme subunit structures (Weeden \& Wendel 1989; Kephart 1990).

\section{Reproc setive Individuals}

The density of reproductive individuals was estimated for all populations. Within each tha quadrat, 6 to 10 sampling plots, each $20 \times 20 \mathrm{~m}$, were placed randomly and all reproductively mature individuals were counted. These were defined as trees exhibiting flowers and/or seed, or $>20 \mathrm{~cm}$ diameter at one metre in height (DMH). Mean densities were used to estimate reproductive population sizes for each patch population. 
Pollen Movement

To assess the potential for pollen movement among patch populations via wind dispersal, pollen trapping was conducted around patch ' $a$ '. This population was surrounded by pasture and was $>1 \mathrm{~km}$ from the nearest $A$. saccharum population. Pollen traps were set along four transects (east, east southeast, south southeast, south) in 1989 and five transects (northeast, east, southeast, south, west) in 1991. Transects were perpendicular to the forest margin with traps every $20 \mathrm{~m}$, from $20 \mathrm{~m}$ within the forest to $460-540 \mathrm{~m}$ beyond the forest. Pollen traps consisted of a microscope slide smeared with petroleum gel, placed in an inverted petri dish lid and mounted $1 \mathrm{~m}$ above the ground on a steel rod. Trapping was conducted from 1 iv 28 May, 1989 and 1 to 21 May, 1990. Early May is the main period of pollen release for A. saccharum in the Ottawa region (Bassett 1969). Traps were replaced every week, or after eaciı rain. Pollen density was estimated for each slide from a $1 \mathrm{~cm}^{2} 25$ point sampling grid, giving a total count area of $44 \mathrm{~mm}^{2}$ per slide.

\section{Data Analysis}

\section{Genetic variation and mating system}

Several measures of genetic variation were estimated for each population: polymorphism $(P)$ - the proportion of loci that are polymorphic, allelic diversity $(A)$ the number of alleles per locus and individual heterozygosity $\left(H_{1}\right)$ - the proportion of loci heterozygous per individual. Polymorphism (arcsine transformed data) and allelic diversity were compared between patches and controls by t-tests. Individual 
heterozygosity (arcsine transformed data) was compared using nested analysis of variance, with populations as subgroups.

To examine population deviation from random mating, inbreeding coefficients ( $\left.F_{15}\right)$ (Wright 1965, 1978), weighted by expected heterozygosity, were estimated. The overall goodness of fit of observed genotype frequencies to those expected under Hardy-Weinberg equilibrium was assessed using chi-square tests for each locus, with - ferrori correction for multiple tests (Weir 1990). For genotypes that invoived rare alleles, and therefore had low expected values, alleles were pooled to create two classes, the most common allele and all other alleles. If expected values were still below five, Fisher's exact tests were used. Least squares linear regression was used to provide a conservative test of the significance of the relationship between mean density of reproductive individuals in a population and mean inbreeding coefficient.

\section{Genetic differentiation}

Several measures of genetic differentiation were estimated separately for patch and control populations. G-tests were used to test for differences in allele frequencies at each locus among populations. When allele frequencies were low or zero, Monte Carlo simulations were used to provide estimates of the significance of $G$ using an algorithm devised by Roff and Bentzen (1989). Fixation coefficients $\left(F_{\mathrm{ST}}\right)$ (Wright 1965, 1978) were calculated, weighted by expected heterozygosity. Nei's minimum genetic distance $\left(D_{\mathrm{m}}\right)(\mathrm{Nei} 1987)$ was estimated for all population comparisons and averaged within and between patches and controls. 


\section{Reproductive individuals}

Nested analysis of variance was used to compare the density of reproductive individuals between patches and controls, using populations as subgroups.

Note: Genetic variation, mating system and genetic differentiation statistics were calculated using the computer program BIOSYS-1.7 (Swofford \& Selander 1989). Unless otherwise stated all statistical procedures followed Sokal \& Rohlf (1981).

\section{RESULTS}

\section{Genetic Variation and Mating System}

Thineen of the 17 loci exhibited allelic variation. A total of 58 alleles were observed in the 16 populations. Population allele frequencies, polymorphism, allelic diversity and individual heterozygosity estimates are presented in Appendix 1. Locus and mean population inbreeding coefficients are presented in Appendix 2.

Genetic variation and mating system summary statistics are presented in Table 1.2. A total of $\mathbf{4 8}$ alleles were observed in the eight patch populations, compared to 54 alleles in control populations. Mean polymorphism was slightly higher in patches than in controls $(\phi=0.065)$. There was no significant difference in mean allelic diversity. On average, patches had a larger proportion (mean $=0.81$ standard error $(\mathrm{SE})=0.01)$ of their allele pool than controls $($ mean $=0.69 \mathrm{SE}=0.02)(p=0.007)$. Of the 44 alleles common to both patch and control populations, 11 (Aat-2: $0.400,0.170$, 
Table 1.2 Genetic variation and mating system summary statistics for A. saccharum patch and control populations

\begin{tabular}{llll}
\hline & $\begin{array}{l}\text { Patch } \\
\text { populations }\end{array}$ & $\begin{array}{l}\text { Control } \\
\text { populations }\end{array}$ & $p$ \\
\hline Total alleles & 48 & 54 & \\
$\begin{array}{l}\text { Mean } \\
\text { polymorphism }(P)\end{array}$ & $\begin{array}{l}0.588 \\
(0.019)\end{array}$ & $\begin{array}{l}0.537 \\
(0.017)\end{array}$ & 0.065 \\
$\begin{array}{l}\text { Mean allelic } \\
\text { diversity }(A)\end{array}$ & $\begin{array}{l}2.10 \\
(0.04)\end{array}$ & $\begin{array}{l}2.03 \\
(0.06)\end{array}$ & \\
$\begin{array}{l}\text { Mean individual } \\
\text { heterozygosity }\left(H_{1}\right)\end{array}$ & $\begin{array}{l}0.121 \\
(0.006)\end{array}$ & $\begin{array}{l}0.109 \\
(0.004)\end{array}$ & 0.087 \\
$\begin{array}{l}\text { Mean inbreeding } \\
\text { coefficient }\left(F_{\text {is }}\right)\end{array}$ & 0.050 & 0.073 & \\
\hline
\end{tabular}

Notes: $n=8$. () standard error. $F_{\text {Is }}$ is weighted by expected heterozygosity. 
Gpi-2: 0.345, Mdhp-4: 0.230, Pgm-1: 0.390, Pgm-2: 0.410, 0.325, Pgm-3: 0.170, Pym-4: 0.155, 0.135, Tpi-1: 0.470) were distributed more widely among patches than controls. The mean increase in spread for these alleles was 2.1 populations (SE=0.3). Only six alleles (Gpi-2: 0.430, 0.270, Pgm-2: 0.315, Pgm-3: 0.235, Pgm4: $0.185,0.140$ ) were distributed more widely among controls than among patches. The mean increase in spread for these alleles was 1.2 populations $(\mathrm{SE}=0.2)$. Mean individual heterozygosity was slightly higher in patches than in control populations $(p=0.087)$. There was no significant difference in inter-population variation in individual heterozygosity between patches and controls.

Based on locus tests, two patch populations (d, e) and one control population (F) deviated significantly from Hardy-Weinberg equilibrium (Appendix 2). All exhibited a deficit of heterozygotes. Mean inbreeding coefficients were very similar for patches and controls (Table 1.2), though coefficients varied widely among loci within populations and among populations within patch and control groups (Appendix 2). There was no significant relationship between the rnean density of reproductive individuals within a population and mean inbreeding coefficient.

\section{Genetic Difrerentiation}

Differences in allele frequencies occurred at six loci (Aat-2, Fba-1, Gpi-2, Pgm-1, Pgm-2. Pgm-4) among patch populations and at four loci (Aat-2, Mdhp-2, Pgm-2, P.sm-4) among control populations (Appendix 1). Fixation coefficients are presented in Appendix 2. The mean fixation coefficient for patches was $F_{\mathrm{st}}=0.019$, very 
similar to the $F_{\mathrm{st}}=0.017$ for controls, indicating that, in both patches and controls. less than $2 \%$ of the observed variation was attributable to differentiation among populations. Nei's minimum genetic distances were also low, and very similar, for patches and controls (Table 1.3).

\section{Reproductive Individuals}

The mean density of reproductive individuals in patches was $5.2(\mathrm{SE}=0.9)$ individuals per $400 \mathrm{~m}^{2}$, slightly lower than in controls: mean $=7.1(\mathrm{SE}=0.3)$ individuals per $400 \mathrm{~m}^{2}(p=0.083)$. Patches had more among-population variation in density than controls $(p=0.001)$. Estimates of reproductive population sizes for patches are presented in Table 1.4.

\section{Pollen Movement}

A sample of the pollen data from 1989 and 1990 , for patch population ' $a$ ', is presented in Fig. 1.2. Comparison of pollen density along the east southeast and east transects for 1989 (Fig. 1.2a and 1.2b) shows that there was directional variation in pollen rain around the source population. Comparison of data from 1989 and 1990 for the east transect (Fig. 1.2b and 1.2c) shows that there was also year to year variation in pollen rain. Compared with 1989, there was little pollen rain in 1990 and very few flowers were observed on trees. However, pollen was still distributed along all transects. 
Table 1.3 Mean Nei's minimum genetic distances $\left(D_{m}\right)$ among $A$. saccharum parch and control populations

\begin{tabular}{lll}
\hline & Patch populations & Control populations \\
\hline $\begin{array}{l}\text { Patch } \\
\text { populations }\end{array}$ & 0.003 & \\
& $(0.001-0.006)$ & \\
Control & 0.003 & 0.002 \\
populations & $(0.001-0.005)$ & $(0.001-0.004)$ \\
\hline
\end{tabular}

Note: () range. 


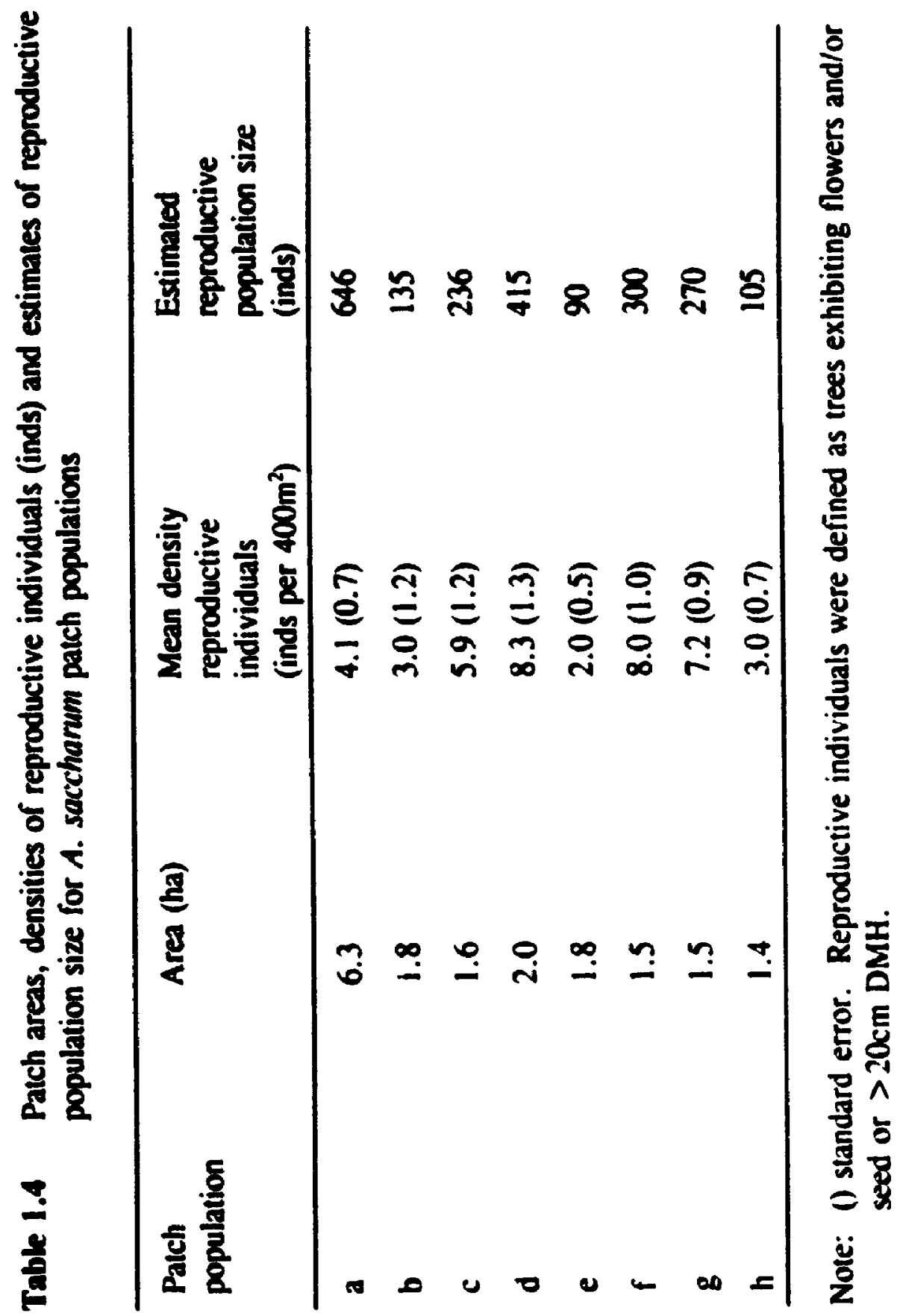



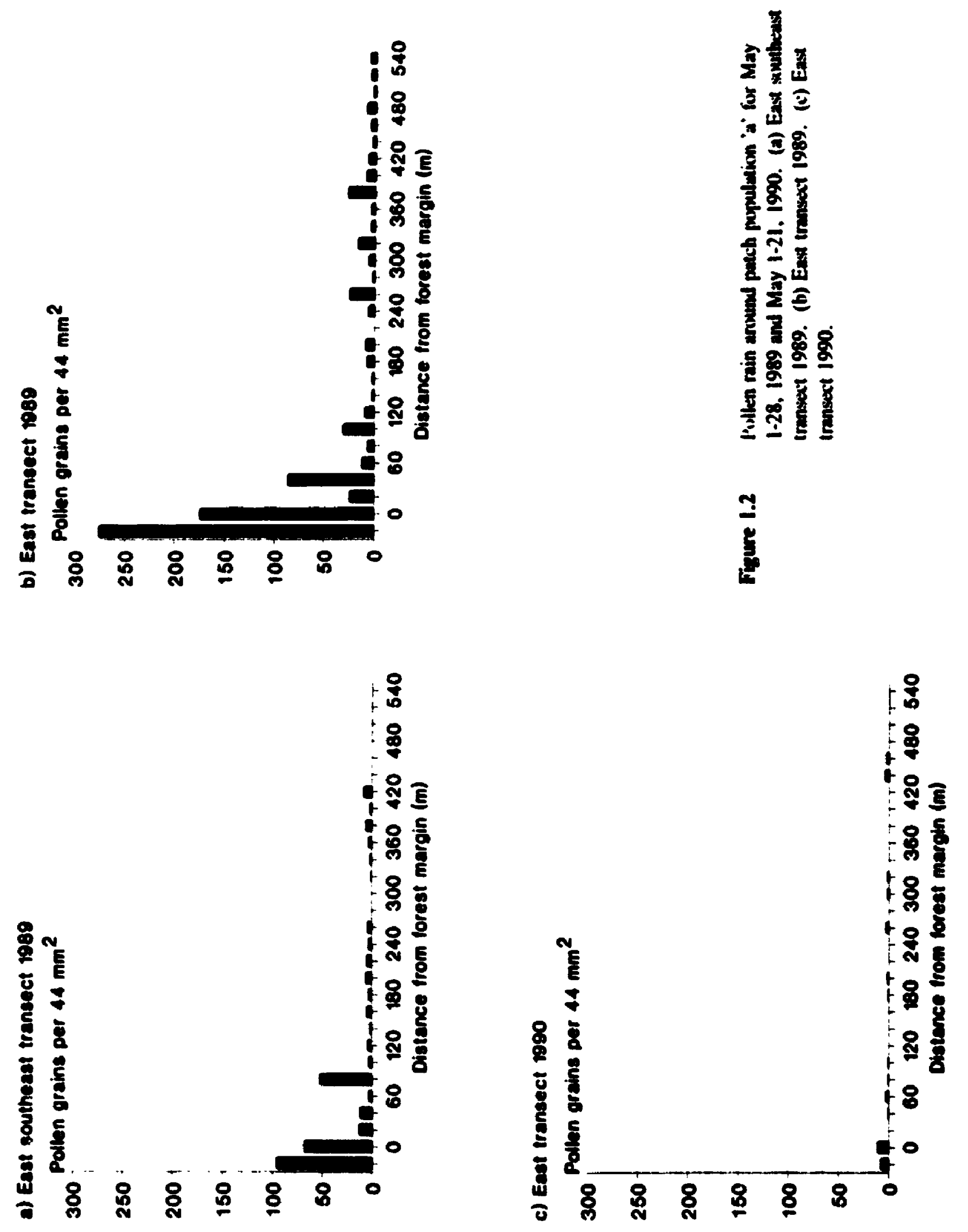


\section{DISCussion}

If the original assumption of this study is correct, i.e. that $A$. sacchurum populations in continuous forest are representative of pre-fragmentation populations. then comparison of polymorphism, allelic diversity and individual heterozygosity. between patch and control populations, shows that forest fragmentation has not led to the expected loss of genetic variation at the population or individual level. Furthermore. there has been no apparent increase in inbreeding in patches. Similarly, based on genetic distances, fixation coefficients and allele frequency comparisons, the amount of differentiation among patch populations has not increased. Forest fragmentation does appear, however, to have affected the overall genetic variation of the forest system, with the eight patch populations having six fewer alleles in total than the eight control populations.

One possible explanation for the maintenance of genetic variation in patch populations is that there has not been enough time since fragmentation for processes such as genetic drift and inbreeding to erode genetic variation, or for mutation and genetic drift to generate among-population differences. Given a minimum age for A. saccharum of 40 years at reproductive maturity, and 100-200 years since the forest was cleared, patch populations may have only gone through 2.5 generations in their present reduced state. It may also be that, from a genetic perspective, population size has not been affected much by forest fragmentation. Reproductive populations found in forest patches (90-646 individuals, Table 1.4) may be larger than groups of individuals that commonly interbreed (breeding associations) within continuous forest. 
If this is the case, rates of genetic drift and inbreeding would not be expected to increase in patch populations.

However, these explanations cannot account for polymorphism and heterozygosity being higher in patch populations than controls. This suggests that within-population and within-individual genetic variation in patch populations has increased since fragmentation, indicating that other processes may be important in determining genetic variation in patches. Patch populations had higher polymorphism than controls because, on average, they had a larger share of their available allele pool. Together with the greater spread of several alleles among patch populations, this suggests that inter-population gene flow is higher among patches than controls. Mudelling data on A. saccharum seed dispersal (Green 1980; Sharpe \& Fields 1982; Guries \& Nordheim 1984; Dirschl 1988), and indirect observations of dispersal by examination of seedling distributions (Benzie 1959; Westman 1968; Johnson 1988), show that seed dispersal is unlikely to account for gene flow among patch populations over common interpatch distances of hundreds of metres. However, the pollen trapping data show that wind dispersal of pollen could provide a gene flow vector over distances of up to $400 \mathrm{~m}$ across pasture fields. Such pollen mediated gene flow among patches might be greater than among populations in continuous forest, where wind speed is lower. pollen is lost to impaction on trees and effective gene flow may be reduced by pollen dilution. If there is more gene flow among patch populations, patches should be more genetically homogeneous than controls. Genetic differentiation results show they were not, suggesting that the increase in gene flow is 
small, or possibly that gene flow is intermittent. This may be the very type of gene flow that wind dispersal of pollen provides. given the large year to year variation observed in pollen rain. A similar scenario has recently been suggested by Fore et al. (1992b) who examined seedling and mature cohorts of A. sacchurum populations in woodlots in Ohio. Fore et al. (1992b) observed less genetic differentiation among the seedling cohorts established after fragmentation than among the mature prefragmentation individuals and concluded that since fragmentation, inter-woodlot gene flow had increased. However, the results of this study should be treated cautiously as sample sizes for mature cohorts were small (one third were $n<5$ ).

There are several possible explanations for the higher individual heterozygosity in patch populations. The simplest is that increased heterozygosity is a reflection of higher polymorphism. Increased outbreeding in patch populations would also result in higher heterozygosity. Such a shift in mating system might be promoted by the lower densities of reproductive individuals in patch populations, with mating occurring among individuals that are further apart and therefore less likely to be related. However, mean inbreeding coefficients for patch and control populations were similar, and there was no apparent relationship between density of reproductive individuals and inbreeding. Finally, selection may be affecting heterozygosity. For example, data on iorest microclimate, from diverse forest ecosystems (Wales 1967; Kapos 1989; Young 1988), have shown that light intensities in small forest patches may be higher than in the interior of continuous forest. Under such conditions there is no advantage to shade tolerance and slow growth: those individuals that dominate 
and reproduce may simply be those that grow most quickly. In contrast in the continuous forest, where canopy gaps provide the opportunity for rapid growth only irregularly, slow sustained growth may be a more effective strategy for reaching reproductive maturity. Several studies have identified relationships between individual levels of protein heterozygosity and growth rate in tree species e.g. Mitton \& Grant (1980). Such a relationship for A. saccharum would provide a mechanism by which heterozygosity might be selected for in patch populations.

The apparent overall loss of six alleles from the eight patch populations is unlikely to be due to increased genetic drift, if gene flow among patches has increased since forest fragmentation. However, it may be the result of founder events that took place when fragmentation occurred. When the forest was cleared many individuals were removed from butween the present forest patches, and some low frequency alleles may not have been included in those that made up the remaining populations. The six alleles (Adh-1: 0.355 , Fba-1: $0.230,0.175$, Gpi-2: $0.450,0.435,0.255$ ) not present in patch populations all occurred in control populations at low frequencies.

Overall, these results show that forest fragmentation has had an effect on genetic variation in A. saccharum populations. Initially, founder effects may have played an important role in determining the genetic variation of $A$. saccharum forest patch populations, by reducing the number of alleles available in the fragmented forest system as a whole. However, contrary to expectations, increased genetic drift and inbreeding have not led to a loss in genetic variation within individuals and populations, and inter-population genetic differentiation has not increased. This may 
be because of the limited number of generations sinee these .1. wathurum pupulations were reduced in size, or because. genetically, population size has not been affected much by fragmentation. Both of these possibilities indicate that life history traits of the species. specifically factors such as longevity and breeding structure. are important in determining the effects of habitat fragmentation. However. the apparent increase in genetic variation in patch populations and patch individuals, despite reduced overall allele pool, combined with the increase in spread of alleles among populations, suggest that genetic variation has been redistributed at these scales, and point to other factors, specifically increased inter-population gene flow and possibly changes in selection regime, as being important determinants of gevletic variation in the A. saccharum forest patch populations. 


\section{Chapter 2: The effects of forest fragmentation on spatial genetic structure}

\section{INTRODUCTION}

Allozyme based studies of genetic variation have shown that. generally, tree species exhibit high levels of intra-population genetic variation (Muona 1990). Recent investigations of the distribution of this variation among individuals have indicated that populations may not be random assemblages of genotypes, but that genetically similar individuals may be spatially associated e.g. Perry \& Knowles (1991); Xie \& Knowles (1991). Such spatial genetic structure can result from several processes. Restriction of gene flow, owing to limited pollen and/or seed dispersal, may produce isolation by distance and subsequent ditferentiation among groups of individuals by genetic drift. In this case, spatial genetic structure reflects breeding associations within populations. Selection may also affect the way genotypes are distributed within populations. Patterns of differentiation among individuals are then the result of the spatial patterns of selection regimes. It is also possible that interactions between life history traits and environmental factors that exhibit spatial and/or temporal dynamics, e.g. reproductive strategy and disturbance regime, could produce nonrandom associations of genotypes (Perry \& Knowles 1991).

Two recent studies of tree populations have shown that populations of the same species can have very different spatial genetic structures, depending on their ecological history and population characteristics. Knowles er al. (1992) observed clumping of allozyme phenotypes in a stand of Larix laricina (Du Roi) K. Koch 
(tamarack) which had regenerated immediately after clear cutting, but not in one that was the result of colonisation of an old farm field from an adjacent stand. This was attributed to differences in founding seed source. with the clear cut stand having an in sifu seed source, possibly reflecting previous genetic structure, whereas the old field population relied on seed from off site sources, with consequently more mixing. Similarly, Boyle ef al. (1990) found spatial genetic structure in a lowland stand of Picea mariana (Mill.) B.S.P. (black spruce), but not in a more dense upland stand. They suggested that this was due to differences in the regeneration dynamics of the two stands, with the lowland stand having regenerated without major disturbance, and the upland stand being the result of regeneration after fire.

Forest fragmentation can result in severe modification of the forest environment and forest tree populations. Fragmentation has been shown to affect forest microclimate (Young 1988; Kapos 1989) and the age structure and density of tree populations (Ranney et al. 1981). It has also been suggested that fragmentation affects disturbance regimes (Saunders et al. 1991) and leads to reduced population sizes (Wilcove 1987). The objective of this study was to investigate the effects of foresi fragmentation on the spatial genetic structure of Acer saccharum populations. Acer saccharum has already been shown to exhibit within-population spatial genetic structure at a scale of $20-30 \mathrm{~m}$ (Perry \& Knowles 1991). Of specific interest was whether forest fragments encompass the spatial and population scales required for maintenance of 'normal' breeding associations that occur in continuous forest. 


\section{METHODS}

\section{Experimental Design and Study Populations}

To determine the effects of forest fragmentation, the spatial genetic structures of four of the A. saccharum patch populations (a-d) from the previous study of genetic variation (Chapter 1) were compared to those of four of the control populations (A-D). The mean density of reproductive individuals in patches was approximately one third lower than in the controls, with three of the patches having densities lower than any of the four controls (Table 2.1). This is probably the result of cutting of trees for wood.

\section{Sampling and Genetic Data}

Within each population 121 first-year seedlings were sampled from the same Iha square quadrat and regular $\|x\|$ sampling grid, with $10 \mathrm{~m}$ intervals between nearest sampling points, as used in the study of genetic variation (Chapter 1). These included the $\mathbf{5 0}$ individuals used in the previous estimations of genetic variation. All seedlings were removed irtact, transplanted into pots and maintained in a greenhouse for the duration of the study.

Following the procedures described in Chapter 1, horizontal starch gel electrophoresis was used to obtain allozyme genotypes for all seedlings from mature leaf tissue samples, for 10 putative polymorphic allozyme loci for seven enzymes. These were: alcohol dehydrogenase (ADH) E.C. 1.1.1.1. (1 locus), aspartate aminotransfierase (AAT) E.C. 2.6.1.1 (1 locus), glucose-6-phosphate isomerase (GPI) 
Table 2.1 Areas and densities of reproductive individuals (inds) for A. saccharum control and patch populations

\begin{tabular}{|c|c|c|}
\hline & Area (ha) & $\begin{array}{l}\text { Mean density } \\
\text { reproductive individuals } \\
\text { (inds per } 4\left(00 \mathrm{~m}^{2}\right)\end{array}$ \\
\hline \multicolumn{3}{|c|}{ Control population } \\
\hline $\mathbf{A}$ & - & $7.4(0.9)$ \\
\hline B & - & $6.9(1.0)$ \\
\hline C & - & $7.5(1.3)$ \\
\hline D & - & $7.1(0.9)$ \\
\hline \multicolumn{3}{|c|}{ Patch population } \\
\hline $\mathbf{a}$ & 6.3 & $4.1(0.7)$ \\
\hline b & 1.8 & $3.0(1.2)$ \\
\hline c & 1.6 & $5.9(1.2)$ \\
\hline d & 2.0 & $8.3(1.3)$ \\
\hline
\end{tabular}

Note: () standard error. Reproductive individuals were defined as trees exhibiting flowers and/or seed or $>20 \mathrm{~cm} \mathrm{DMH}$. 
E.C. 5.3.1.9 (1 locus), glyceraldehyde-3-phosphate dehydrogenase (GAPDH) E.C. 1.2.1.12 (1 locus), malate dehydrogenase (MDHP) E.C. 1.1.1.37. (NAD) (1 locus), phosphoglucomutase (PGM) E.C. 5.4.2.2 (4 loci), triose-phosphate isomerase (TPI) E.C. 5.3.1.1. (1 locus).

\section{Spatial Analyses}

Spatial autocorrelation (Cliff \& Ord 1981) and nearest neighbour analysis (Clark \& Evans 1954) were used to investigate the spatial distribution of allozyme genotypes among individuals within the eight populations. For each population, only alleles that occurred in at least three individuals and which could occur in $<n-2$ individuals $(n=$ sample size) were included in the analyses. This gave $15-21$ alleles per population.

For spatial autocorrelation analysis, allelic data were coded so that each allele was a variable existing in an individual in one of three states: $1=$ homozygote, $0.5=$ heterozygote, $0=$ absent. If only two alleles were present at a locus only information from a single allele was used. Moran's I spatial autocorrelation coefficient was calculated following Cliff \& Ord (1981) (Appendix 3) for each allelic variable, for nine classes of separation distance between individuals: $10-14.1 \mathrm{~m}, 14.2-$ $28.3 \mathrm{~m}, 28.4-42.4 \mathrm{~m}, 42.5-56.6 \mathrm{~m}, 56.7-70.7 \mathrm{~m}, 70.8-84.9 \mathrm{~m}, 85-99 \mathrm{~m}, 99.1-113.2 \mathrm{~m}$, 113.3-141.4m, using the FORTRAN program SAAP (Wartenberg 1989). As shown in Appendix 3, Moran's $l$ is a form of product-moment correlation coefficient, with the numerator a measure of covariance among individuals designated as a 'join', that 
is separated by the distance class of interest. and the denominator a similar measure of variance. Moran's I was tested for significance under the randomisation assumption as a standard normal deviate (Cliff \& Ord 1981) (Appendix 3) using Bonferroni correction (Weir 1990) for the multiple tests for each distance class provided by the allelic variables. Values of $I$ greater than the expected value of $E(I)$ (Appendix 3) indicate that genotypes at a given distance are more similar than expected by chance, while values of $/$ lower than $E(I)$ indicate less similarity than expected. Initially, for two populations. control ' $B$ ' and patch ' $a$ ', alleles in tive different frequency classes: $<0.1,0.1-0.249,0.25-0.749,0.75-0.899,>0.9$, were analyzed separately. All frequency classes, with the exception of the 0.25-0.749 class, which contained few (2-4) alleles in any of the populations, were found to be equally informative. This supports the observations of Sokal \& Jacquez (1991) that spatial autocorrelation is independent of gene frequency. Therefore, subsequent analyses for the eight populations combined alleles of all frequencies.

For all alleles with frequencies $<0.1$, nearest neighbour analysis was conducted following Clark \& Evans (1954) and using Donnelly's (1978) corrections for finite populations (Appendix 4). Boyle et al. (1990) have demonstrated that nearest neighbour analysis is more sensitive to localised clustering of such low frequency alleles than spatial autocorrelation using Moran's $l$. Clark-Evans ratios, of mean observed distance $\left(r_{A}\right) /$ expected distance $\left(r_{B}\right)$ to nearest neighbour, $<1.0$ indicate spatial contagion of genotypes. Ratios $>1.0$ indicate a regular distribution. Significance was assessed using $r_{A}$ as a standard normal deviate (Clark \& Evans 1954) 
(Appendix 4). A neighbour 'match' was considered to be the presence of an allele in either heterozygous or homozygous form.

\section{RESULTS}

Clark-Evans ratios from nearest neighbour analyses, for low frequency $(<0.1)$ alleles, for all populations, are presented in Table 2.2. None of the distributions of these alleles deviated significantly from random in any of the control or patch populations. However, a large proportion of the observed ratios were $>1 ; 23$ out of 27 ratios for controls and 29 out of 38 ratios for patches. This overall trend towards regular distributions is probably the result of sampling on a grid.

Spatial autocorrelation results are presented as spatial correlograms of mean Moran's I by distance class (Figs 2.1-2.3), together with overall significance for each distance class as assessed by Bonferroni criteria. Control population 'D' showed no deviation from a random distribution of genotypes (Fig. 2.1). Control populations ${ }^{\prime} \mathrm{A}{ }^{\prime}, \mathrm{B}^{\prime}$ and ${ }^{\prime} \mathrm{C}$ ' also showed no spatial genetic associations at distances $<28.3 \mathrm{~m}$ (Fig. 2.1). Beyond this, all three populations exhibited non-random associations of genotypes at various distances. However, there were no obvious trends in genetic similarity across distance classes, either in Moran's $I$, or type of association i.e. positive or negative, and there was little consistency in genetic associations for distance classes among populations. Mean Moran's / values for control population 'B'. for distance classes $42.5-56.6 \mathrm{~m}, 70.8-84.9 \mathrm{~m}$ and $113.3-141.4 \mathrm{~m}$, did not match the overall significance for these distances. In each case this was because significance 
Tuble 2.2

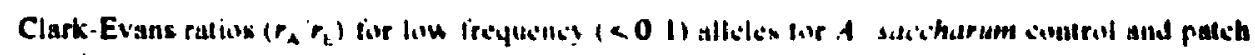
pepulations

\begin{tabular}{|c|c|c|c|c|c|c|c|c|c|}
\hline \multirow[b]{2}{*}{ Locus } & \multirow{2}{*}{$\begin{array}{l}\text { Alleie } \\
\left(R_{1}\right)\end{array}$} & \multicolumn{4}{|c|}{ Control mipulations } & \multicolumn{4}{|c|}{ Patch poyulatuons } \\
\hline & & $\mathbf{A}$ & B & c & D & 4 & h & $\therefore$ & 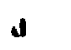 \\
\hline \multirow[t]{3}{*}{ Aar.2 } & 0.400 & . & . & . & - & 13 & & & \\
\hline & 0.170 & - & - & - & . & 115 & - & - & 150 \\
\hline & 0.150 & - & - & 103 & & & 10.3 & & \\
\hline \multirow[t]{5}{*}{ Cpi-2 } & 0.430 & 1.47 & - & 0.89 & . & 1.09 & - & 106 & 1.29 \\
\hline & 0.335 & 1.17 & 128 & 1.07 & 1.17 & 1.42 & 112 & 1.24 & . \\
\hline & 0.325 & - & $1+7$ & 1.16 & 1.17 & 107 & 101 & 1.20 & 128 \\
\hline & 0.270 & 0.99 & . & 1.04 & - & . & 134 & & $0 \%$ \\
\hline & 0.255 & - & 1.35 & - & . & . & 1.39 & & 107 \\
\hline Caputh-2 & 0.220 & - & . & 138 & . & . & - & . & . \\
\hline Methp-4 & 0.230 & 1.14 & - & - & 1.28 & & - & 09.1 & 099 \\
\hline Pgm-1 & 0.390 & . & . & - & - & . & 065 & & \\
\hline \multirow[t]{3}{*}{ Pgm-2 } & $0 .+10$ & 1.04 & - & 1.24 & 0.90 & 1.26 & 121 & 112 & 10.1 \\
\hline & 0.325 & - & 1.57 & . & - & 1.16 & 1.14 & 103 & \\
\hline & 0.315 & - & - & . & 1.22 & 1.24 & 1.09 & 118 & 150 \\
\hline Pgm-3 & 0.170 & $\cdot$ & - & - & 1.62 & . & - & & \\
\hline \multirow[t]{2}{*}{ Pgm-4 } & 0.140 & 1.05 & 0.95 & 1.66 & $\cdot$ & . & & 084 & 1.11 \\
\hline & 0.135 & - & - & & - & 0.85 & . & & . \\
\hline$T p i \cdot 1$ & 0.470 & . & . & 1.01 & 1.07 & 0.83 & . & 0.65 & 090 \\
\hline
\end{tabular}




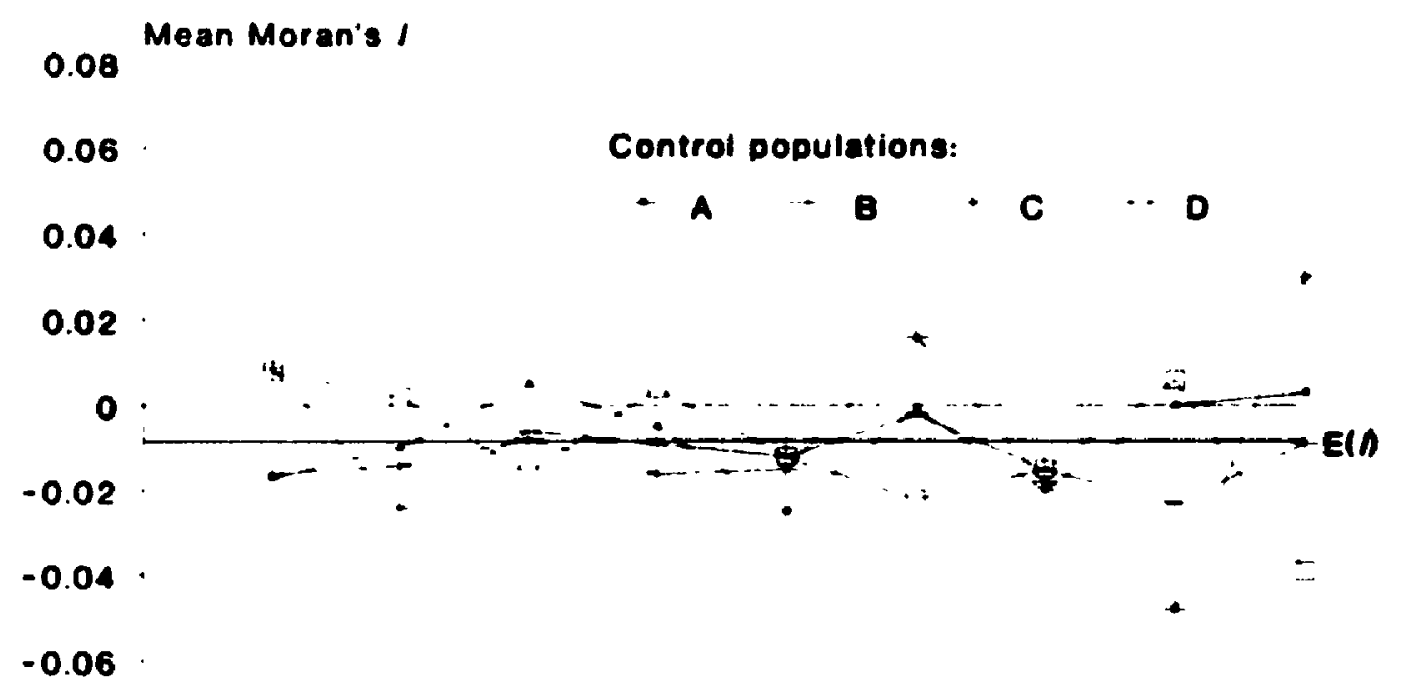
$-0.08$
$\begin{array}{llllllllll}0 & 14.1 & 28.3 & 42.4 & 56.6 & 70.7 & 84.9 & 99 & 113.2 & 141.4\end{array}$ Upper distance class limit (m)

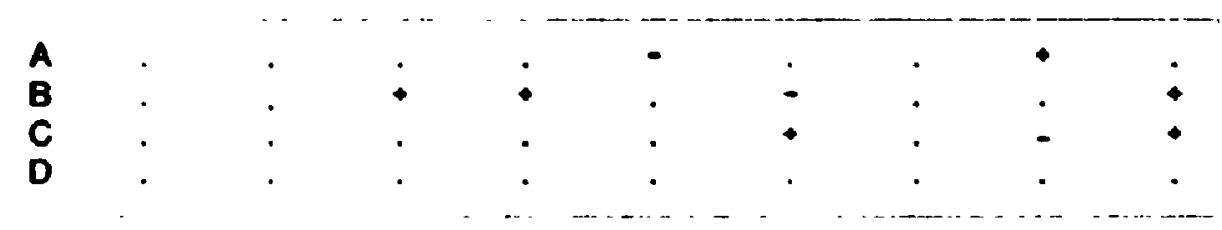

Figure 2.1 Spatial correlogram of mean Moran's $I$ by individual separation distance class for A. sacchurum control populations (A, B, C, D). E( $I$, ex, pected Moran's $l$. Box gives overall sigaificance $(p<0.05)$ of genetic association fo, each distance class: + positive association, - negative association, . no deviation from random. Number of alleles used in analyses for each population: A:15. B:16, C:17, D:15. 
was conferred by the spatial distribution of a single allele: (jpi-2: 0.325 . Gupulh-2:

0.275 and Pgm-2: 0.325, respectively (Fig. 2.2).

Between $14.2 \mathrm{~m}$ and $113.2 \mathrm{~m}$, spatial autocorrelation results for patches were similar to those for controls, with populations exhibiting non-random genetic associations at various spatial scales, but no trends in genetic similarity with distance or consistency among populations (Fig. 2.3). At the shortest distance class $(10-14.1 \mathrm{~m})$, three of the four populations $(a, b, c)$ had mean Moran's / values $>E(I)$, and two of these, populations ' $b$ ' and ' $c$ ', showed significant positive assiciation of genotypes. Similarly, at the longest distance class $(113.3-1+1 .+11)$, all populations had mean Moran's $/$ values < $E(h)$, with populatirins ' $b$ ' and ' $c$ ' showing significant negative associations of genotypes. These results at the shortest and longest distances sampled, and their general consistency across the patch populations, contrast with results from controls.

\section{DISCUSSION}

Though nearest neighbour analyses show no localised spatial clumping of genotypes. spatial autocorrelation indicates that both controls and patches, with the apparent exception of control population 'D', did exhibit spatial genetic structure.

Furthermcre, comparison of Moran's / for the shortest and longest distance classes suggests that patterns of genetic similarity among individuals show some differences between patch and control populations. If control populations are good 


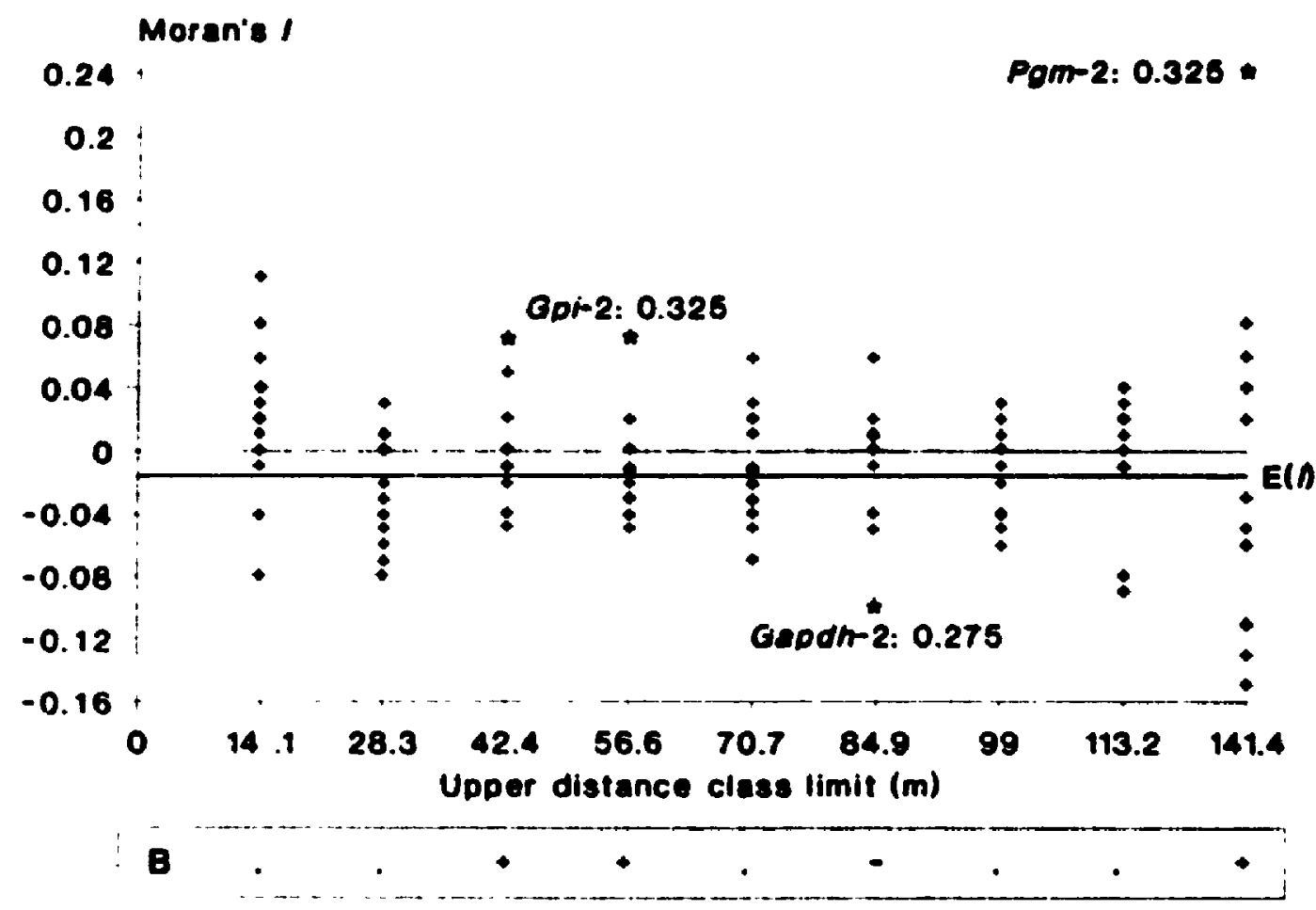

Figure 2.2 Moran's $l(+)$ by individual separation distance class for the 16 alleles analyzed for A. saccharum control population 'B'. For any distance class values for several alleles may be the same. Box gives overall significance $(p<0.05)$ of genetic association for each distance class: + positive association, - negative association, . no deviation from random. - Moran's / for alleles that confer overall significance. 


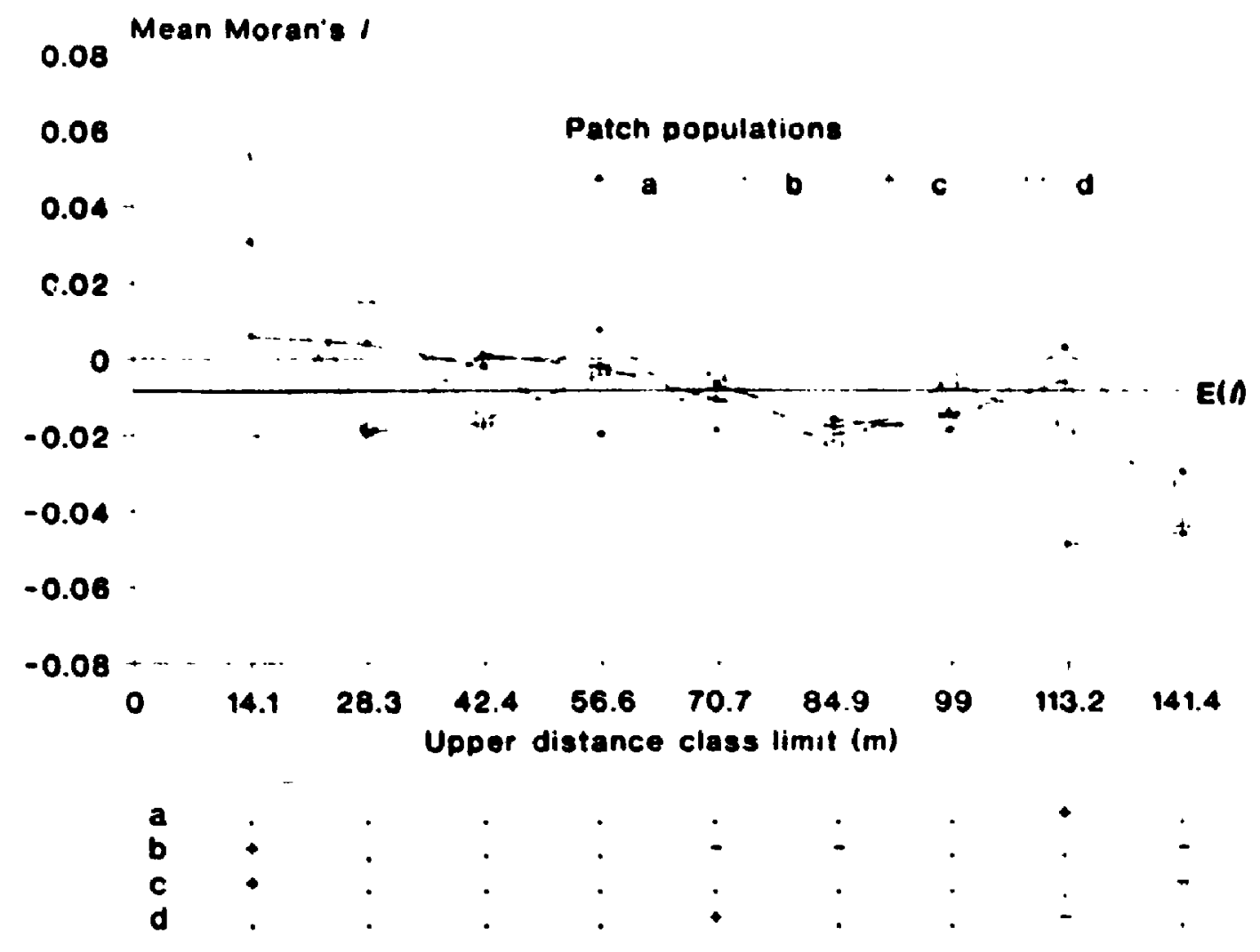

Figure 2.3 Spatial correlogram of mean Moran's / hy individual separation distance class fer A. saccharum patch populations (u, h. c, d). E(l) expected Moran's I. Box gives overall significance $(p<0.05)$ of genetic assckiatoon fior each distance class: positive association. - negative assiciation. - no devialion from random. Number of alleles used in analyses for each population: a:21, h:17, c:17, d:19. 
representations of the genetic structure of patches prior to forest fragmentation, then fragmentation has affected the genetic structure of patch populations.

For control populations 'A', 'B' and ' $C$ ', spatial autocorrelation results indicate that genotypes were not distributed randomly within populations. However, Moran's / did not decline with increasing distance between individuals as suggested by Barbujani (1987) for neutral loci under isolation by distance. These results contrast with those of Perry \& Knowles (1991), from three naturally regenerated A. saccharum stancis, for similar spatial scales and sample sizes, using approximately the same number of alleles. Perry \& Knowles (1991) sampled individuals of all ages, and reported clumping of similar allozyme phenotypes up to distances of $20-30 \mathrm{~m}$ in all populations, and suggested that this may have been the result of limited pollen and/or seed dispersal.

This does not mean that the spatial genetic structures in control populations are not the product of patterns of mating. Acer saccharum is heterodichogamous, with trees being either protogynous or protandrous. Within a population, blooming of flowers may be spread over up to 10 days (Gabriel 1968). However, the duration of blooming for individual trees can be as short as two days for both male and female Nowers (Gabriel 1968). Therefore, patterns of mating may be primarily determined by the spatial distribution of flowering times among trees, and the genetic structures observed in controls, with positive and negative associations at various distances, could result from correlations among half-sib progeny of parental trees with complementary flowering periods, that are spread throughout the population. 
Differences in the distribution of trees with complementary thowerng perionls would then account for observed among-poputation differences in patterns of genetic similarity with distance. Murauski \& Hamrick (1991) have described a smilar scenario for several tropical angiosperm trees, in which they suggest that the lining of flowering of individual trees is important in determining mating relationships. It this is the case, the positive Moran's / values over the longest distance class for control populations ' $\mathrm{B}$ ' and ' $\mathrm{C}$ ' indicate that pollen movement is extensive, with breeding associations extending over the whole area sampled and possibly beyond, though not encompassing all individuals within the area because of differences in flowering period. Presumably, if flowering time is genetically controlled, which Gabriel (1968) suggests that it is, based on year to ycar consistency in the blexming habit of trees, then such breeding associations inay be temporally stable. This inay account for the positive inbreeding coefficients previously observed for patch and control populations (Chapter 1 - Appendix 2), which may reflect a Wahlund effect owing to sampling seedlings from several such spatially coincident, but phonologically isolated, breeding associations.

Selection can also influence the distribution of genotypes withın populatıons, and Perry \& Knowles (1991) also proposed microgeographic selection as a possible mechanism for generating spatial genetic structure in the $A$. saccharum stands that they studied. Since selection is unlikely to affect all loci equally, it may be detected by differences between spatial genetic patterns of alleles at loci subject to selection compared with neutral loci (Sokal \& Wartenberg 1983; Epperson 1990). None of the 
patch or control populations had consistently different patterns of Moran's I with disiance for any alleles. One possible reason for a limited effect of selection is that the population cohort examined was first-year seedlings, which had undergone only a subset of lifetime selection events. Though Foré et al. (1992a) has found allozyme allele frequency differences between embryo and seedling cohorts in $A$. saccharum, which may reflect selection at germination, most selection probably occurs later, during the major mortality period of the first 15 years (Forcier 1973). Furthermore, if selection were generating genetic structure. it would require a very complex spatial distribution of the environmental variables responsible to produce the observed genetic patterns, and environmental paich sizes would have to be small $(<10 \mathrm{~m}$ diameter). The similarity of spatial autocorrelation results for patch and control populations, between $14.2 \mathrm{~m}$ and $113.2 \mathrm{~m}$, suggests that, over a large range of the scales examined, the same processes were generating genetic structure. The different patterns of genetic associations among individuals at the shortest and longest distances in patches presumably reflect changes in either population or environment, resulting from forest fragmentation, that have affected these genetic processes. The genetic similarity of individuals at distances $<14.2 \mathrm{~m}$ may be due to lower densities of reproductive individuals in patches. Johnson (1988) has shown that, in open field conditions, $A$. sactharum seed dispersal is reducej by an order of magnitude by $30 \mathrm{~m}$ from the seed source, and Guries \& Nordheim (1984) suggest that dispersal within forest may be further reduced, as samaras are knocked out of autogyration by impaction on trees. Therefore, within-population seed dispersal is probably quite 
limited, which should lead to clumping of related individuals. This uas not observed in control populations, possibly because the density of reproductive individuals resulted in significant overlapping of seed shadous, with consequent mising of progeny of different maternal origins (Fig. 2.4a). In patch populations, with their lower densities of reproductive individuals. overlap of seed shadows may not be as great (Fig. 2.4b). Therefore, half-sib progeny around maternal trees may form distinct and identifiable patches that are large enough to be detected by the shortest individual comparisons made, that is $>10 \mathrm{~m}$ diameter.

The negative Moran's $/$ values between $113.3 \mathrm{~m}$ and $141.4 \mathrm{~m}$ in patch populations probably relate to limited patch area. Three of the four patch populations (b, c. d) were only slightly larger than the Iha sampling area, therefore comparisons of individuals in patches at this scale, were comparisons among individuals at opposite edges of a forest patch. This may generate the observed negative genetic associations in two ways. First, mating events at these edges may be incorporating immigrant pollen from other forest patch populations. Pollen trapping results from the previous study (Chapter 1 - see Fig. 1.2) have shown that wind dispersal of pollen is a possible gene flow vector over common interpatch distances. If different forest edges receive pollen from different sources, depending on the spatial arrangement of surrounding forest patches, prevailing wind patterns and pollinator movements, genetic associations among edge individua!s will reflect any differences in allele frequencies among these immigrant pollen pools. Secondly, Wales (1967) has shown that the microclimate of torest edges may be different, depending on aspect. If flowering is at 


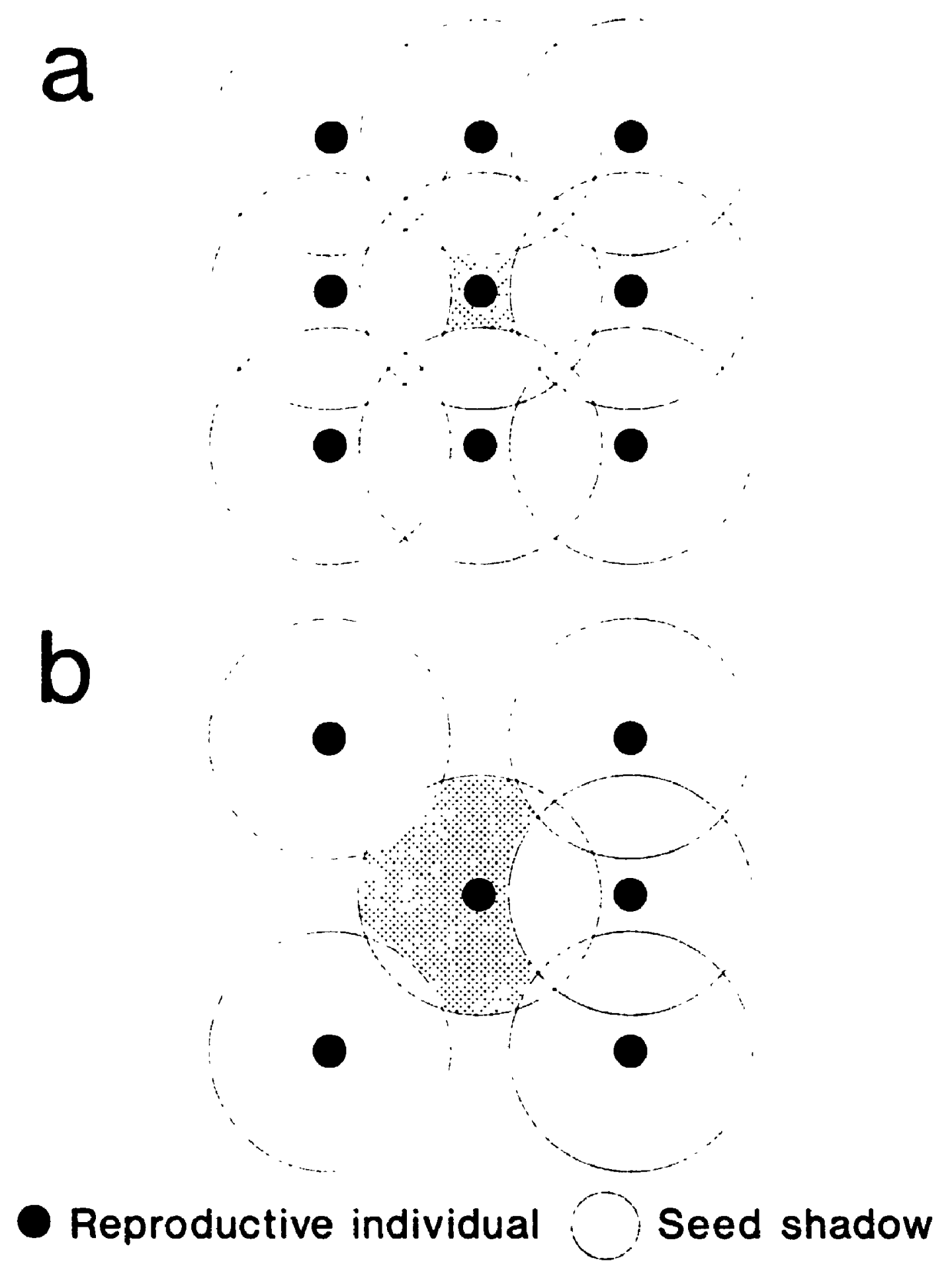

Figure 2.4 Hypithetlical seed shadows around reproductive A. saccharum trees. Shaded area denotes patich of half-sith progeny. a) Control population. b) Patch population with density of reproductive individuals one third lower than control. 
all affected by microclimate, then negative assckiations among individuals at difterent forest edges may be because of differences in flowering times of edge trees, which prevent inter-edge mating events.

Overall these results suggest that mating may be an important provess in generating genetic structure in both control and patch populations of $A$. waithurum. Patterns of mating among individuals are probably determined to some extent by individual flowering time and, in control populations, are apparently not limited by pollen dispersal over the scales examined. In patch populations, it would appear that fragmentation has impacted on genetic structure of the seedling cohort, pussibly by affecting patterns of gene flow and mating. Patch populations of 1-2ha may no longer be large enough to encompass the spatial scales of mating events occurring in breeding associations within continuous forest populations. This suggests that the argument from Chapter 1 that patch populations have not lost genetic variation through inbreeding and genetic drift, because populations are bigger than 'normal' breeding associations, is incurrect. Furthermore, matings occurring at patch edges may be incorporating immigrant pollen, possibly generating mating relationships among individuals at greater scales than generally observed in continuous populations, which are reflected in seedling genotypes. In contrast, the spatial mixing of genotypes at short range in patches has been reduced, possibly by increased isolation of seed shadows around reproductive individuals, which occur at reduced densities in forest patches. Though there was no evidence of the action of selection in generating genetic structure in these seedling cohorts, a role for selection in later life history 
cannot be discounted based on these data. This may account for the observed differences between the results of this study and those obtained by Perry and Knowles (1991). More generally, the results of this study indicate the need for more realistic models of mating relationships and gene flow for forest trees if these are to be successfully incorporated into an understanding of within-population genetic structure. The spatial patterns of genetic variation described here are not simple functions of individual separation distance. Certainly. the addition of a temporal component to the spatial elements generally considered should prove instructive. 


\section{Chapter 3: The effects of forest fragmentation on genetic variation and spatial genetic structure among cohorts}

\section{INTRODUCTION}

As discussed in the previous chapter. allozyme studies indicate that both gymnosperm and angiosperm tree species exhibit high levels of intra-population genctic variation. Furthermore, this genetic variation may be distributed non -randomly among individuals, and groups of individuals, within populations. Most studies of withinpopulation genetic structure have Jealt with spatial genetic differentiation. However, recent data suggest that tree species may also exhibit significant genetic differences among cohorts within populations. Shea (1990) observed significant allele frequency differences among seedlings, saplings and adults in two stands of Picea engelmannii (Parry) Engelm. (Engelmann spruce) and levels of genetic differentiation, as assessed by $F_{\mathrm{ST}}$, similar to that observed among stands. Similar results were obtained by Roberds \& Conkle (1984) for a stand of Pinus raeda L. (loblolly pine), in which genetic differentiation among three cohorts was greater than that observed among spatial subdivisions within the stand. Genetic differentiation was also observed among cohorts within two populations of Gleditsia triacamthos L. (honey locust), a leguminous tree, by Schnabel \& Hamrick (1990) and differences in heterozygosity were found among embryos, saplings and adolescents, within four populations of

Pinus radiara D. Don. (Monterey pine) by Plessas \& Strauss (1986).

Such differences in genetic variation among different aged cohorts within populations can provide information about population genetic processes. For 
example. Schaal \& Levin (1976) interpreted through-cohort changes in heterozygosity and $F_{\text {is }}$ statistics for allozyme loci, as strong evidence for selection in a population of the perennial herb Liarris cylindracea Michx. Similar inferences about selection have been made by Plessas \& Strauss (1986) for allozyme variation in $P$. radiata. Two studies have been conducted comparing genetic variation among cohorts in Acer saccharum. Mulcahy (1975) suggested that differences in general esterases observed among seedling cohorts from year to year, reflected differences in selection pressures that prevailed during early growth and establishment. Fore et al. (1992a) proposed that differences between embryo and seedling cohorts, in the frequency of isozyme variants at the Lap locus, represented selection occurring during first-year mortaity.

The objective of this study was to determine the effects of forest fragmentation on patterns of genetic variation and spatial genetic structure among cohorts within an A. saccharum population, and through this, to investigate changes in genetic processes that may have occurred in fragmented populations. By examining spatial genetic structure in different aged cohorts it should also be possible to address the more general question of which processes are important in generating structure in A. saccharum. Some processes that have been suggested as being important in previous studies of tree species, such as mating (e.g. Murawski \& Hamrick 1991) and seed dispersal (e.g. Knowles et al. 1992), act before germination, and structure resulting from these should be evident in initial seedling cohorts. Other processes, such as selection (e.g. Epperson \& Allard 1989), have a temporal component, 
therefore resulting genetic structure takes time to develop and will be more clearly observed in older cohorts.

\section{METHODS}

\section{Experimental Design and Study Populations}

To determine the effects of forest fragmentation. genetic variation and spatial genetic structure in each of four cohorts of control population ' $A$ ' (control) and patch population ' $a$ ' (patch) from the previous studies (Chapters $I$ and 2) were compared. Based on seedling data from Chapter 1 (Appendix 1), control population 'A' exhibited moderate genetic variation relative to other control populations. iatch population ' $a$ ' exhibited the highest genetic variation observed among patch populations (Appendix 1). The mean density of reproductive individuals in patch 'a' was 4.1 individuals per $400 \mathrm{~m}^{2}(\mathrm{SE}=0.7)$, approximately $40 \%$ lower than in control ' $A$ ': mean $=7.4$ individuals per $400 \mathrm{~m}^{2}, \mathrm{SE}=0.9(p<0.01)$ (Chapter 2 - see Table 2.1).

\section{Sampling and Genetic Data}

Four developmentally based cohorts were sampled within each population. The first cohort was first-year seedlings, for which genetic data were already available from the previous two studies (Chapters 1 and 2). These individuals were sampled within a few weeks of germination and represent the pcpulation prior to significant postgermination mortality. The second cohort, juvenıles, were individuals $<1 \mathrm{~cm}$ in diameter and $<1 \mathrm{~m}$ in height. These individuals, which may be as old as 15 years, 
(Hult \& Loucks 1971), represent the population after the major mortality of the first year, which can approach $50 \%$ (Forcier 1973). The third cohort, poles, were $5-15 \mathrm{~cm}$ DMH and represent the population atter most mortality has taken place (Forcier 1973). The final cohort was reproductive individuals, as previously defined in Chapter 1 as trees exhibiting flowers and/or seed or $>20 \mathrm{~cm}$ DMH.

Within each population, individuals were sampled from within the same tha square quadrat as used in the previous two studies (Chapters 1 and 2). For estimating genetic variation, 44-50 individuals from each cohort were randomly sampled using the same $1 \mid x \| 1$ sampling grid, with $10 \mathrm{~m}$ intervals between nearest sampling points. For pole and reproductive cohorts, when an individual was not present at a sampling point, the nearest individual was used. For spatial analyses, an additional 71 individuals of the juvenile cohort were sampled to complete the survey of the 121 point sampling grid, as had been done previously for seedlings (Chapter 2), while for the pole and reproductive cohorts, as many more individuals as possible were sampled and the positions of all individuals were mapped. This gave cohort sample sizes of 103 and 73 poles and 85 and 44 reproductive individuals for the control and patch population respectively, with an estimated sampling intensity of $40-45 \%$.

Horizontal starch gel electrophoresis was used to obtain allozyme genotypes from mature leaf tissue samples from all individuals. Electrophoresis and data interpretation procedures followed Chapter 1, with the exception that tissue samples from the three older cohorts were kept on ice for up to 12 hours before enzyme extraction. Eleven putative allozyme loci were resolved clearly and consistently for 
all cohorts. These were: alcohol dehydrogenase (ADH) E.C. 1.1.1.1 (1 locus). fructose-biphosphate aldolase (FBA) E.C. 4.1.2.13 (1 locus). glucise-6-phosphlate isomerase (GPI) E.C. 5.3.1.9 (2 loci), glyceraldehyde-3-phosphate dehydrogenase (GAPDH) E.C. 1.2.1.12 (2 loci), malate dehydrogenase (MIDH) I.C. 1.1.1.37 (NAD) (2 loci), phosphoglucomutase (PGM) E.C. 5.4.2.2 (2 loci) and triosephosphate isomerase (TPI) E.C. 5.3.1.1 (1 locus).

\section{Data Analysis}

Estimates of genetic variation, mating system and genetic differentiation followed the procedures in Chapter 1. Analysis of variance was used to test for differences among cohorts in individual heterozygosity $\left(H_{1}\right)$ (arcsine transformed data) and allelic diversity $(A)$. $G$-tests were used to test for differences in genotype frequencies at each locus among cohorts. When genotype frequencies were low, Monte Carlo simulations were used to provide estimates of the significance of $G$, using an algorithm devised by Roff \& Bentzen (1989).

Spatial autocorrelation analysis, using Moran's / spatial autocorrelation coefficient (Cliff \& Ord 1981) (Appendix 3), and nearest neighbour analysis (Clark \& Evans 1954) (Appendix 4), were used to investigate the spatial distribution of allozyme genotypes among individuals within each cohort, following the procedures in Chapter 2. The three monomorphic loci: Gpi-1, Gapdh-1 and Mdh-1 were excluded from spatial analyses, as was $M d h-2$, which exhibited only a single variant individual. Between six and 13 alleles were analyzed for each cohort. The same individual 
separation distance classes were used for spatial autocorrelation analyses as in Chapter 2: 10-14.1m, 14.2-28.3m, 28.4-42.4m, 42.5-56.6m, 56.7-70.7m, 70.8-84.9m, 85$99 \mathrm{~m}, 99.1-113.2 \mathrm{~m}, 113.3-141.4 \mathrm{~m}$. Pearson's product-moment correlation coefficient was used to test for correlations of Moran's / among cohorts within a population by distance.

Note: Unless otherwise stated all statistical procedures followed Sokal \& Rohlf (1981).

\section{RESULTS}

\section{Genetic Variation, Mating System and Genetic Differentiation}

Eight of the 11 loci exhibited allelic variation. A total of 26 alleles were observed in the control population and 28 in the patch. Allele frequencies for all four cohorts, for both the control and patc'l populations, are presented in Appendix 5.

Polymorphism $(P)$, allelic diversity $(A)$, individual heterozygosity $\left(H_{1}\right)$ and inbreeding coefficients $\left(F_{\text {ts }}\right)$, for each cohort, for both populations, are presented in Table 3.1. For the control population, the proportion of polymorphic loci was the same for ail cohorts $(P=0,455)$, and there were no significant among-cohort differeaces in either allelic diversity or individual heterozygosity. In the patch population, there was greater variation among cohorts for both polymorphism $(P=0.545-0.636)$ and individual heterozygosity. Seedlings $\left(H_{1}=0.157\right)$ exhibited significantly higher heterozygosity than poles $\left(H_{1}=0.100\right)$, but seither were 


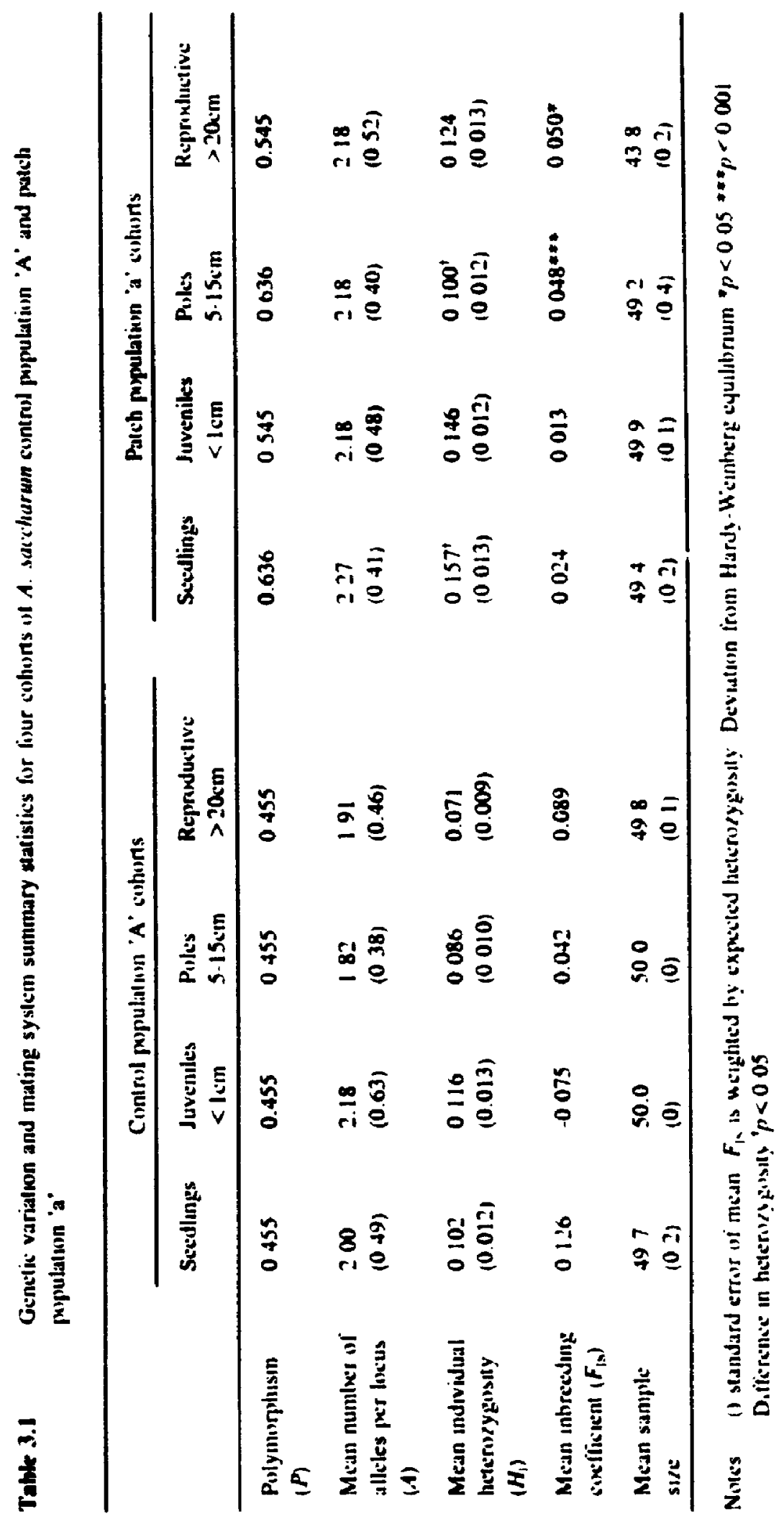


significantly different from the other two cohorts. There was no trend in either polymorphism or heterozygosity with cohort age. There were no significant differences in allelic diversity among cohorts in the patch population.

Based on locus tests, none of the control population cohorts deviated significantly from Hardy-Weinberg equilibrium, though there was variation in inbreeding coefficients among cohorts (Table 3.1) and among loci within cohorts (Appendix 6). In the patch population. the two oldest cohorts both exhibited overall significant deficits of heterozygotes. Locus inbreeding ccefficients (Appendix 6) show that this was the result of a deficit of heterozygotes at Pym-1 in poles and at Adh-1 in reproductive individuals. Inbreeding coefficients show a steady increase in the deficit of the Adh-1: 0.320/0.275 heterozygote with increasing cohort age (Appendix 6) and frequencies of the three possible genotypes were significantly different among cohorts $(p<0.01)$.

There were significant allele frequency differences among cohorts, in both the control and patch populations, for Adh-1 and Pgm-2 (Appendix 5). For the control population the reproductive cohort was different from the other cohorts for $A d h-1$. Seedlings were different for Pgm-2, specifically reflecting the occurance of the Pgm2: 0.410 allele, which was not found in any of the other three cohorts. In the patch population, poles were different from other cohorts for $A d h-1$, while poles and seedlings were different from the other three cohorts, for Pgm-2. Agaın, seedlings had a high frequency of the Pgm-2: 0.410 allele compared with other cohorts. 
Fixation coefficients are presented in Appendix $t$. The mean tivation coctricient for the control population cohorts was $F_{\mathrm{s}}=0.013$. only slightly lower than for the patch cohorts $F_{\mathrm{sr}}=0.017$. Mean Nei's minimum genetic destance among control c. horts was $D_{\mathrm{m}}=0.002(\mathrm{SE}=0.001)$, similar to that for patch colorts: $D_{\mathrm{m}}=(0 .(1) .3$ $(\mathrm{SE}=\mathbf{0 . 0 0 1 )}$.

\section{Spatial Genetic Structure}

Clark-Evans ratios from nearest neighbour analyses, for low frequency $(<0.1)$ alleles, for all cohorts and both populations are presented in Table 3.2. Nonc of the distributions of these alleles deviated significantly from random in any cohorts. for either the control or the patch population. As with the results for seedlings in Chapter 2, most of the observed ratios were $>1$, and this probably reflects the grid sampling method that was used.

Spatial autocorrelation results are presented as spatial correlograms of mean Moran's / by distance class for each cohort, together with significance for cach distance class, as assessed by Bonferroni criteria (Fig. 3.1 and Fig. 3.2). In the control population the reproductive cohort showed no deviation from a random distribution of genotypes (Fig. 3.1). The three younger cohorts all exhibited positive associations of genotypes at individual separation distances greater than $99 \mathrm{~m}$, but no significant associations, either positive or negative, among individuals separated by distances less than this, with the exception of the genetic similarity among poles at 14.2-28.3m. Exc spt at the longest distance class, mean Moran's / values were 
55

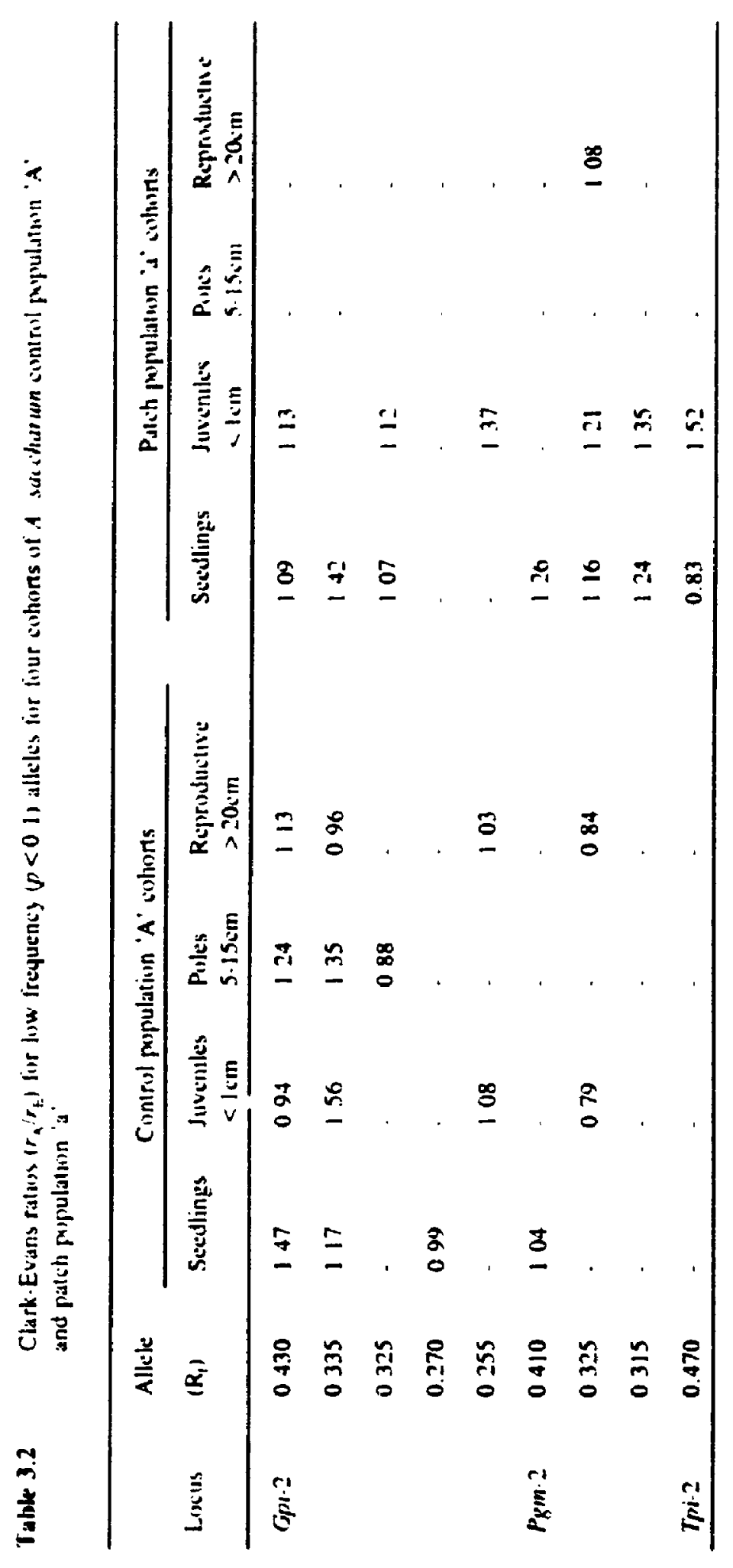




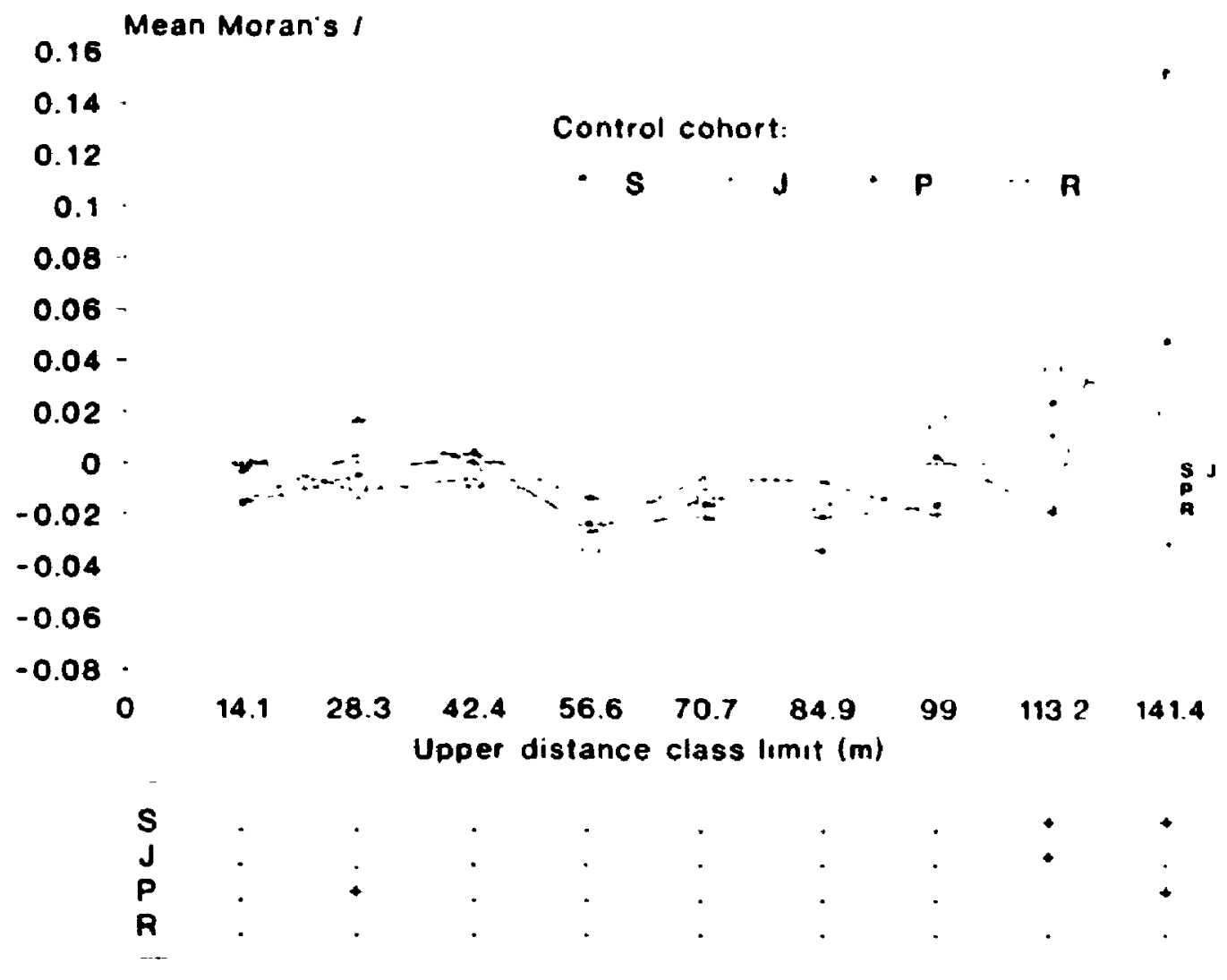

Figure 3.1 Spatial correlogram of mean Moran's / by individual weparation distance class lor four cohorts within A. saccharum control population 'A'. S: veedlings. J: juveniles $P$ : poles, R: reproductive individuals. Broken lines represent E(l) expecled Moran' I for each cohort. Box gives overall significance $(p<0.05)$ of genetle assex talluon fus each distance class: + posslive asuccation. - negalive assoclation. . no devialion from random. Number of alleles used in analyses for each cohort. Seedling. 8 . Juveniles: 10. Poles: 7, Reproductive individuals: 9. 
sunilar among cohorts, with a positive correlation between seedlings and poles $(r=0.79, p<0.05)$ and a weak positive correlation between seedlings and reproductive individuals ( $r=0.63, p=0.07)$. As with the seedling data from the previous study (Chapter 2), there were no trends in genetic similarity with individual separation distance for any of the cohorts.

Patch population cohorts exhibited no significant genetic associations among individuals separated by distances between $28.4 \mathrm{~m}$ and $99 \mathrm{~m}$ (Fig. 3.2). At distances greater or less than this there were both positive and negative associations among individuals, but there were no trends in genetic similarity with separation distance, either in Moran's /, or the nature of association i.e.positive or negative. There were no significant correlations of Moran's $I$ among any of the four cohorts. For the 99.111.3.2m distance class, cohorts actually exhibited opposite patterns of genetic similarity, with seedlings and reproductive individuals separated by this distance being more similar than expected and poles being less genetically alike. Similarly, at the shortest distance class, there were large among-cohort differences in mean Moran's $I$.

\section{DISCUSSION}

The four cohorts examined in the control population were genetically very similar. Gelletic differentiation among cohorts was lower than inter-population differences among control populations in Chapter 1, with fewer loci exhibiting allele frequency diffierences, though the mean fixation coefficient among cohorts $\left(F_{\mathrm{ST}}=0.013\right)$ was only slightly lower than the among populations $F_{\mathrm{ST}}=0.017$ and Nei's minimum genetic 


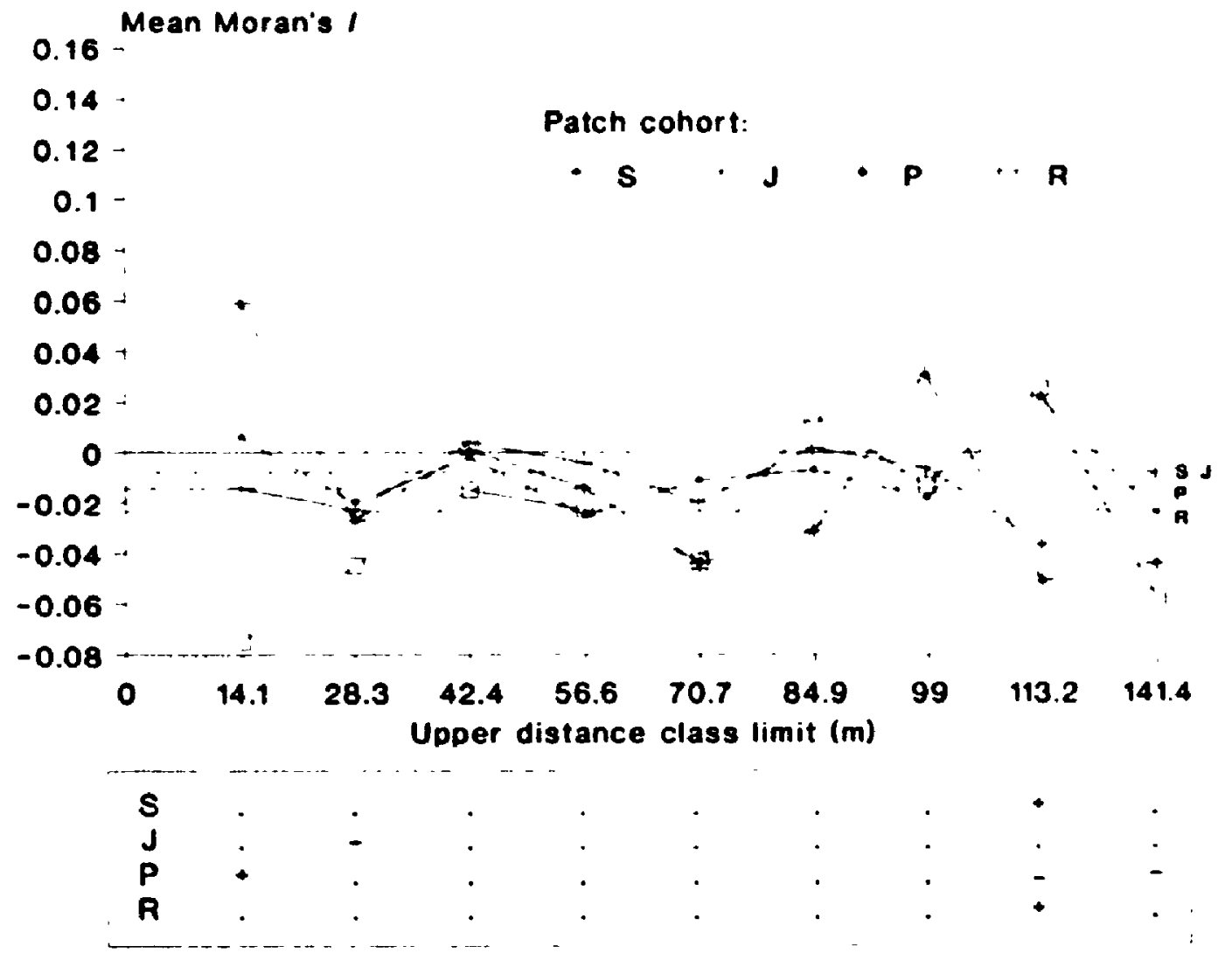

Figure 3.2 Spatial correlogram of meon Moran's / hy individual separation divtance classs for four cohorts within A. sacchorum patch population 'a". S: secoling', J: fuveniles, P:poles, $R$ : reproductive individuals. Broken lines represent $E(I)$ expected Moran's I for each cohort. Box gives overall significance $(p<0.05$ ) of genellic asvexiation fur each distance class: + positive association, - negatıve assecialion, . no deviation from random. Number of alleles used in analyses for each cohort: Secedlings: 13 , Juveniles: 12, Poles; 7. Reproductive individuals: 6. 
distances were similar (among-population $D_{\mathrm{m}}=0.003$, among-cohort $D_{\mathrm{m}}=0.002$ ). This level of differentiation was lower than that found among $P$. raeda cohorts by Roberds \& Conkle (1984) $\left(F_{\mathrm{sr}}=0.042\right)$. All cohorts were in Hardy-Weinberg equilibrium and there were no significant differences in amount of genetic variation $\left(P, A, H_{1}\right)$, or trends in variation or inbreeding coefficients with cohort age, such as those observed by Plessas \& Strauss (1986) for $P$. radiata, which might suggest the action of selection. This also indicaies that other processes that generate genetic variation e.g. mating, have not changed significantly between the inception of the different cohorts. These results and conclusions are very similar to those of Foré (f al. (1992a) for allozyme variation in five cohorts of $A$. saccharum, ranging from embryos to canopy individuals, in a large old-growth beech-maple forest in Ohio. Foré el al. (1992a) found no differences in estimates of genetic variation $\left(P, A, H_{0}-\right.$ mean heterozygosity per locus) among cohorts, and a Nei's $(1973 ; 1977)$ genetic diversity statistic (equivalent to multilocus Wright's $F_{\mathrm{ST}}(1965 ; 1978)$ ), among cohorts of $G_{\mathrm{st}}=0.012$, almost ident $\approx$ al to the $F_{\mathrm{sT}}=0.013$ obtained for the four cohorts in this study.

In the patch population, the greater variation in polymorphism among cohorts, and the significant differences in individual heterozygosity between seedlings and poles. suggest that the four cohorts are not as genetically cohesive as those in the control population. This is weakly supported by the slightly higher among-cohort fixation coefticient $\left(F_{\mathrm{st}}=0.17\right)$. If the original assumption of this study is correct, this reduced cohesion among cohorts within the patch population may reflect changes 
in population genetic processes owing to forest fragmentation. One pessible explanation is that increased inter-cohort variation has resulted from the same changes in inter-population gene flow postulated as the cause of increased levels of genetic variation observed in patches in Chapter 1 and the negative genetic associations among patch edges observed in Chapter 2. Immigrant pollen pool allele frequencies may vary from year to year owing to variation in local wind patterns, pollinator behaviour, and the relative amount of tlowering among other populations. All of these may influence the mating events which give rise to individuals making up patch population cohorts. Similarly, periodic removal of reproductive individuals from the patch population, by tree cutting, may have impacted mating relationships within the population at various times. It may be these changes in mating patterns through time. which are now reflected in the differences in variation among cohorts.

The deviation from Hardy-Weinberg equilibrium in the patch pole cohort, resulting from a deficit of heterozygotes at $P g m-1$, is probably of little biological significance, as expected genotype frequencies involving any alleles apart from the most common Pgm-1: 0.410 , are low. In contrast, the positive inbreeding coefficient for patch reproductive individuals reflects a pattern of increasing heterozygote deficit at the Adh-1 locus with increasing cohort age. One explanation for this is selection against the $A d h-1: 0.320 / 0.275$ heterozygote. As no such trend was observed for Adh-1 in the control population, this may reflect a significant change in selection regime resulting from forest fragmentation. A pattern of increased heterozygote deficit with age is unusual, as most evidence from trees points to selection for 
heterozygotes e... Farris \& Mitton (1984); Yazdani et al. (1985), and the only clear change in cohort genetic variation identified for $A$. saccharum by Foré er al. (1992a) was an increased frequency of a heterozygous genotype at the Lap locus. Another possible explanation is that $A d h-1$ heterozygotes are large vigorous trees, and that the heterozygote deficit in the patch population reproductive cohort is the result of selective cutting of Adli-1 heterozygous individuals. Whichever the scenario, based on these data, it is clear that selection for individual heterozygosity is unlikely to play a role in generating elevated levels of genetic variation in patch populations as was hypothesised at the end of Chapter 1.

Apart from the results for $A d h-1$ in the patch populations, data from the Pgm-2 locus provide the only real evidence for the action of selection in shaping the genetic composition of these two A. saccharum populations. In both populations, the Pgm-2: 0.410 allele occurred with a frequency of about $10 \%$ in the seedling cohort, however it was eliminated from the other cohorts of the control population, and nearly eliminated from other cohorts in the patch population. This may indicate that the Pgm-2: 0.410 allele is highly deleterious, or is tightly linked to genes that are, and that genotypes involving $P_{g} m-2: 0.410$ are strongly selected against during early mortality. However, the virtual absence of this allele from the reproductive cohort of either of these two populations raises the question of how can seedling cohorts have a relatively high occurance of Pgm-2: 0.410 if the possible parental trees within the population exhibit the allele at only a low frequency, or not at all? A second explanation for the observed patterns of occurance of the Pgm-2: 410 allele is that its 
expression is dependent upon the developmental stage of the individual sampled, and that in individuals older than seedlings. the $P_{. g} m-2: 0 .+10$ gene is generally no longer actively producing proteins.

The spatial genetic structures of cohorts in the control population were generally similar to those observed for seedling cohorts of control populations in Chapter 2. More importantly, the spatial genetic structures of the four cohorts were very similar to each other, as shown by the positive correlations of Moran's / values among several cohorts $4 . .5$ seedlings and poles. This means that the process(es) that generate genetic structure in this population act prior to the inception of the youngest of the four cohorts examined. Such a result would appear to rule out a significant role for selection in generating geretic structure in this population, as selection acts on cohorts through time by differential mortality. Furthermore, as argued in Chapter 2 , if selection were generating genetic structure, then structure should consistently be the result of genetic associations at the particular loci which are either under selection, or linked to loci that are (Sokal \& Wartenberg 1983; Epperson 1990). As with the seedling results from Chapter 2, this was not the case tor the control population data for the four cohorts. Overall significant spatial associations were generated by alleles at various loci, suggesting that alleles are acting simply as multiple genetic markers. Though these results do not eliminate the possibility that selection may act between the unsampled embryo cohort and seedlings, through mortality at germination, as suggested by Foré ef al. (1992a) for the Lap locus, they do suggest that its role in generating genetic structure is probably limited. 
Given this, the spatial genetic structures observed in the four control population cohorts probably reflect patterns of mating, as the other inajor process that affects the distribution of genetic variation among individuals prior to the inception of the first-year cohort. The among-cohort similarity in spatial genetic structure then supports the hypothesis outlined in Chapter 2, that mating relationships, and therefore breeding associations, may have considerable temporal stability, possibly owing to the genetic control of flowering time. Results similar to these were obtained by Schnabel \& Hamrick (1990), who found spatial genetic structure in both juvenile and adults of a population of $G$. rriacunthos, suggesting that within-population genetic structure may become established in young cohorts and persist.

The greater among-cohort variation in spatial genetic structure in the patch population suggests that forest fragmentation has affected the genetic process(es) generating structure. presumably, primarily mating. It seems most likely that this would be through the disruption of any stable mating relationships existing in pre-fragmentation populations owing to changes in patterns of inter-population and intra-population gene flow as discussed previously with regard to among-cohort differences in genetic variation.

These results show that the $A$. saccharum control population exhibited little genetic differentiation among cohorts and considerable inter-cohort continuity of spatial genetic structure, indicating that processes generating genetic variation and structure have not changed much through time. Furthermore, they suggest that these processes operate prir-rily early in life history, certainly prior to the inception of 
first-year seedlings. Though the elimination of the Pym-2: $\$ 10$ allele from the control population provides some evidence for selection. its general effect appears limited. and mating is probably the process with most influence on the genetic compusition of large relatively continuous $A$, saccharum populations. The reduced genetic cohesion observed in the patch population points to a significant effiect of forest fragmentation on the genetic composition, presumably as a result of changes to population genetic processes. There is some evidence from the Adh-1 locus that fragmentation may have changed the selection regime of the patch poptiation, possibly resulting in selection against heterozygotes. However, this is unlikely to explain all of the increased among-cohort heterogeneity. The greater part of this is best explained by a disruption of stable within-population mating patterns owing to changes in inter-population and intra-population patterns of gene flow, resulting from torest fragmentation and related effects, such as cutting of reproductive trees within patch populations.

Finally, the similarity in genetic variation and spatial genetic structure among cohorts in control populations suggests that the seedling samples from control populations used for the other two studies (Chapters 1 and 2) probably represent the genetic variation and structure of the populations quite well. Seedlings inay be less reliable genetic representatives of patch populations. 


\section{Chapter 4: Cenetic variation and structure at three spatial scales and the implication: for conservation}

\section{INTRÍDUCTION}

The short term ecological success of species is dependent upon the ability of individuals to survive and reproduce. Given this, habitat requirements and demographics should be considered in species' conservation strategies. However, conservation management must also consider factors that influence species' long term evolutionary dynamics, the most important of which is genetic variation.

As previously discussed, allozyme data show that tree species generally exhibit high intraspecific genetic variation compared to other plants (Muona 1990). This variation may be distributed non-randomly at various levels of organisation (e.g. individuals, populations) within species. Studies of both angiosperms and gymnosperms have identified genetic differentiation among groups of individuals within stands e.g. Piciea mariana (Mill.) B.S.P. (black spruce) (Boyle et al. 1990). Similarly, differences in genetic variation have been demonstrated among stands within forests e.g. Pinus ponderosa Laws. (ponderosa pine) (Linhart et al. 1981), Pimus radiara D.Don (Monterey pine) (Moran et al. 1988), and among populations across continental species' ranges e.g. Pseudorsuga menziesii (Mirb.) (Douglas fir) Franco (Li \& Adams 1989).

If conservation strategies for tree species are to address evolutionary dynamics, data such as these suggest that both the amount of genetic variation and the distribution of variation within a species (genetic structure) at different scales, must be 
taken into account for two reasons. First. Knowledge of intraspecific genctic variation and structure should allow a more representative sample of the species" genetic variation to be included in conservation planning. This is important to minimise the genetic impact of any management strategy and. as pointed out by Hamrick (198.3). to take account of locally adaptive variation. Second, and more importantly, the distribution of genetic variation must be considered because genetic structure retlects. at least in part, the action of population generic processes e.g. selection, genetic drift. It is the functioning of these processes. as well as the maintenance of intraspecitic variation per se, that is fundamental to the maintenance of evolutionary process.

The objectives of this study were to combine data from the previous studies of genetic variation and structure in Acer saccharmm (Chapters 1 and 2) with data from more widely distributed populations, to compare the anount and distribution of genetic (allozyme) variation in $A$. saccharum at three spatial scales: i) among populations across the species' range in Canada, ii) among populations within a single region, iii) among individuals within populations, and to determine the genetic processes that are important in generating genetic structure at these different scales.

\section{METHODS}

\section{Experimental Design and Study Po sulations}

Genetic variation was assessed in nine A. saccharum populations that were distributed throughout the species' range in Canada, generally separated by several hundred kilometres. These were designated as 'regional' populations. Eight of these were 
iscated in national parks: Cape Breton Highlar.us (CB) and Kejimkujik (KJ) in Nova Scotla, Fundy (FF) in New Brunswick. Forillon (FR) and la Mauricie (MM) in Quibec and (jeorgian Bay (BY), Point Pelee (PP) and Pukaskwa (PK) in Ontario (Fig 4. la and 'rable 4.1). Control population ' $A$ ' from the previous studies (Chapters 13), which was located in Gatineau Park, Québec, was used as the ninth regional population: Gatineau 'A'. Data from this population, along with the other seven control populations (A-H) within Gatineau Park (Fig. 4. Ib and Table 4.1) were used for comparison and discussion of genetic variation among local populations within a region. These populations were separated by $1.7-17.9 \mathrm{~km}$ of forest dominated by A. saccharum along with Fugus grandifolia Ehrh. (beech), Quercus rubra L. (red oak), Tilia americama L. (basswood) and Tsuga canadensis (L.) Carr. (eastern hemlock). For four of these populations information on genetic variation and genetic processes at the within-population scale were available for discussion from Chapter 2.

\section{Sampling and Genetic Data}

Within each of the regional populations, 50 first-year seedlings were sampled haphazardly from a square quadrat of approximately lha. All seedlings were removed intact, trans, ' thed into pots, and maintained in a greenhouse for the duration of the study. Sampling for the local and within-population scales, for populations ' $A{ }^{\prime} \cdot{ }^{\prime} H^{\prime}$ ', is outlined in Chapters $I$ and 2.

Horizontal starch gel electrophoresis was used to obtain allozyme data for all scedlings. Electrophoresis and data interpretation procedures followed Chapter 1. 


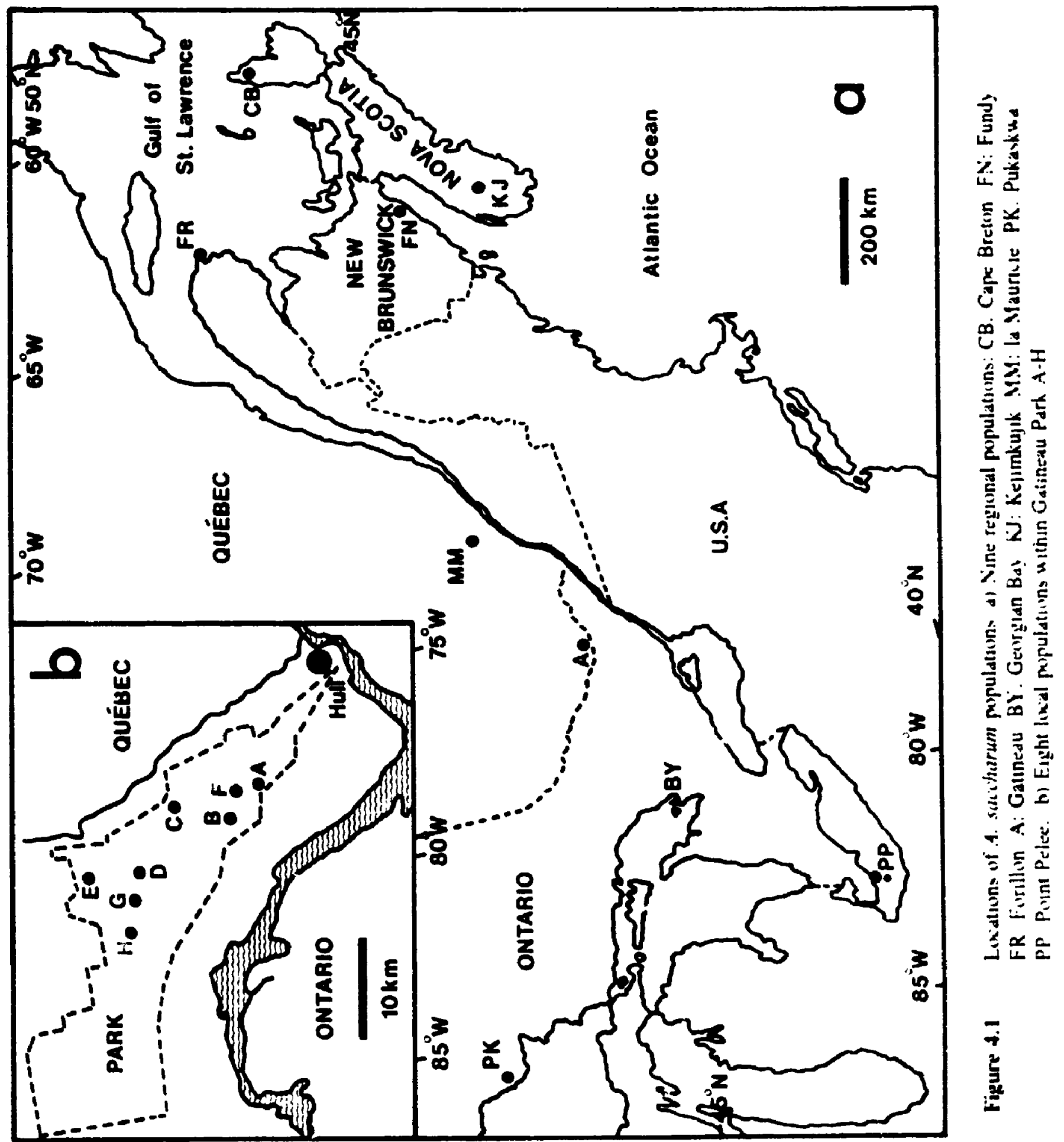


Table 4.1 Locations of nine regional and eight local populations of $A$. saccharum

\begin{tabular}{|c|c|c|c|}
\hline Population & Code & $\begin{array}{l}\text { Latitude } \\
(\mathrm{N})\end{array}$ & $\begin{array}{l}\text { Longitude } \\
\text { (W) }\end{array}$ \\
\hline \multicolumn{4}{|l|}{ Regional } \\
\hline $\begin{array}{l}\text { Cape Breton } \\
\text { Highlands }\end{array}$ & $\mathrm{CB}$ & $46^{\circ} 48^{\circ}$ & $60^{\circ} 44^{\circ}$ \\
\hline Fundy & FN & $45^{\circ} 35^{\prime}$ & $64^{\circ} 59^{\circ}$ \\
\hline Forillon & FR & $48^{\circ} 53^{\circ}$ & $64^{\circ} 23^{\circ}$ \\
\hline Gatineau & A & $45^{\circ} 29^{\circ}$ & $75^{\circ} 52^{\circ}$ \\
\hline Georgian Bay & BY & $44^{\circ} 51^{\circ}$ & $79^{\circ} 52^{\prime}$ \\
\hline Kejimkujik & KJ & $44 \div 2$ & $65^{\circ} 16^{\circ}$ \\
\hline la Mauricie & $\mathbf{M M}$ & $46^{\circ} 41^{\circ}$ & $72^{\circ} 53^{\circ}$ \\
\hline Point Pelee & PP & $41^{\circ} 58^{\circ}$ & $82 \circ 32$ \\
\hline Pukaskua & PK & $48^{\circ} 04^{\prime}$ & $85^{\circ} 43^{\circ}$ \\
\hline \multicolumn{4}{|l|}{ Local } \\
\hline Gatineau & A & $45^{\circ} 29^{\circ}$ & $75^{\circ} 52^{\circ}$ \\
\hline Gatineau & $\mathbf{B}$ & $45^{\circ} 31^{\prime}$ & $75^{\circ} 55^{\prime}$ \\
\hline Gatineau & $\mathrm{C}$ & $45^{\circ} 34^{\circ}$ & $75 \circ 52^{\prime}$ \\
\hline Gatineau & D & $45^{\circ} 36^{\circ}$ & $75^{\circ} 58^{\circ}$ \\
\hline Gatineau & $E$ & $45^{\prime \prime} 37^{\prime}$ & $75^{\circ} 58^{\prime}$ \\
\hline Gatineau & $\mathrm{F}$ & $45^{\prime \prime} 30^{\circ}$ & $75^{\circ} 53^{\prime}$ \\
\hline Gatineau & $\mathrm{G}$ & $.15 \circ 35^{\circ}$ & $76^{\circ} 00^{\circ}$ \\
\hline Gatineau & $\mathrm{H}$ & 1.5036 & $76^{\circ} 03^{\circ}$ \\
\hline
\end{tabular}

Note: Local populations $(\mathrm{A}-\mathrm{H})$ are the same as contro! populations $(A-H)$ in Chapter 1. 


\section{Data Analysis}

Estimates of genetic sariation. mating system and generic difierentation followed procedures in Chapter 1. Canonical discriminant analysis was performed on individual genotype data using a SAS CANCON (SAS Institute lnc. 1988) proxedure with each population treated as a group. For each individual. allelic datd for polymorphic loci were coded following Smouse and Neel (1977). For a locus with three alleles: $A, a$ and $a^{\circ}$ the genotypes: $A A, A a, A a^{\circ}$, aa, aa ${ }^{\circ}$ and $a^{\circ} a^{\prime}$ are cocked as: $10,0.50 .5,0.50,01,005$ and 00 . This generated $n-1$ independent variables for each locus ( $n=$ number of alleles). If data were missing the most common genotype for that locus in the population was substituted. The Georgian Bay population had the most missing data $(6.6 \%)$ and the Gatineau ' $E$ ' population had lle least $(0 \%)$.

Correspondence between estimates of genetic distance and geographic distance among populations was assessed using Mantel tests for matrix correlation and Monte Carlo simulations to generate a null distribution of the $Z$ statistic, following Simouxe ef al. (1986). This avoided making assumptions about the shape of the distribution of $Z$ which is not clear (Dietz 1983; Smouse at al. 1986).

This amount of gene flow among populations, and subsets of populations, was assessed by estimating $\mathrm{Nm}$, the number of migrants per generation, using Slatkin's Rare Alleles method corrected for a sample size of 50 individuals (Slatkın 1985; Slatkin \& Barton 1989). This method is based on an empirical relatwonship belween the mean frequency of alieles found in only one deme (private alleles) and Nm. It 
assumes non-overlapping generations and an island model of population structure, but is robust to deviations from this model.

\section{RESULTS}

\section{Regional and Local Population Genetic Variation}

Four of the 17 loci examined: Gpi-1, Gapdh-1, Mdh-1 and $M d h p-1$, were monomorphic in all individuals. The other 13 loci exhibited variation in at least one individual. Allele frequencies and population estimates of allelic diversity, polymorphism and mean individual heterozygosity for regional and local populations are presented in Appendix 7 and Appendix $2 \mathrm{~b}$ respectively. Genetic variation summary statistics are presented in Table 4.2 .

Generally there was more variability in amount of genetic variation among regional populations than among local populations (Table 4.2). There were no significant differences in allelic diversity among either regional or local populations. There were significant differences in individual heterozygosity among regional populations $(p<0.01)$, but not among local populations. Heterozygosity was higher in Pukaskwa than in Point Pelee or Cape Breton $(p<0.05)$ and also higher in Forillon and la Mauricic than in Cape Breton $(p<0.05)$. Fifty alleles were observed in total over the nine regional populations compared with 54 among the eight local pupulations. However, there were five alleles (Fha-1:185, Gpi-2:0.425, 0.295, Tpi1:0.375, Tpi-2:0.295) found in the regional sample that were not present in any of the lacil populations. 
Table 4.2 Genetic variation summary statistics for $A$. suctharum regional and local populations

\begin{tabular}{|c|c|c|}
\hline & $\begin{array}{l}\text { Regional populations } \\
(n=9)\end{array}$ & $\begin{array}{l}\text { Local populations } \\
(n=8)\end{array}$ \\
\hline Total alleles & 50 & 54 \\
\hline $\begin{array}{l}\text { Mean polymorphism } \\
(P)\end{array}$ & $\begin{array}{l}0.516 \\
(0.412-0.588)\end{array}$ & $\begin{array}{l}0.537 \\
(0.471-0.588)\end{array}$ \\
\hline $\begin{array}{l}\text { Mean allelic diversity } \\
(A)\end{array}$ & $\begin{array}{l}1.93 \\
(1.76-2.18)\end{array}$ & $\begin{array}{l}2.03 \\
(1.82-2.41)\end{array}$ \\
\hline $\begin{array}{l}\text { Mean individual } \\
\text { heterozygosity }\left(H_{1}\right)\end{array}$ & $\begin{array}{l}0.115^{* *} \\
(0.088-0.138)\end{array}$ & $\begin{array}{l}0.1(199 \\
(0.094-0.120)\end{array}$ \\
\hline
\end{tabular}

Notes: () standard error. Difference in heterozygosity ${ }^{* *} p<0.01$. 


\section{Regional and Local Population Mating System}

Locus and mean inbreeding coefficients $\left(F_{1 s}\right)$ for regional and local populations are presented in Appendix 8 and Appendix $2 b$ respectively. Among regional populations mean coefficients ranged from $F_{1 \mathrm{~V}}=-0.084$ in Forillon to $F_{1 \mathrm{~s}}=0.156$ in Point Pelee, with four populations exhibiting negative coefficients and five populations positive values. Local populations exhibited a more restricted range of inbreeding coefficients $F_{12}=-0.010-0.177$, and cextficients for all but one local population $(\mathrm{H})$ were positive. Within both regional and local populations there was considerable variation among locus coefficients for a given population. Chi-squared tests on locus genotype frequencies showed that three regional populations. Forillon $(p<0.01)$, Georgian Bay $(p<0.05)$ and Point Pelee $(p<0.05)$ deviated significantly from Hardy-Weinberg equilibrium (Appendix 8). Forillon had an excess of heterozygotes while Georgian Bay and Point Pelee had deficits. Among local populations only population 'F' showed deviation from Hardy-Weinberg equilibrium $(p<0.05)$ exhibiting a deficit of heterozygotes.

\section{Regional and Local Population Differentiation}

Ten of the 13 polymorphic loci showed significant differences in allele frequencies among regional populations (Appendix 7). Among local populations only four loci exhibited significant allele frequency differences (Appendix lb). The mean fixation coefficient for regional populations averaged across loci was three times that for local populations (Table 4.3 and Appendices 8 and 2b). Nei's minimum genetic distances 
and geographic distances among regional and local populations are presented in Appendix 9. The mean minimum genetic distance and the range of distances anong regional populations were three times the mean distance and fistance range fur lowal populations (Table 4.3). There was weak positive correlation between genetic distance and geographic distance for both regional $(r=0.30 p<0.1(0)$ and l(xial $(r=0.35 p<0.10)$ populations.

Figure 4.2 shows the distribution of regional and local pupulation centroids on the first two canonical axes. In total. canonical variables 1 and 2 accounted for $44 \%$ of the variation in the recoded data. Variable 1 was dominated by loadings for Fha1, Gpi-2 and Mdhp-2. Variable 2 was dominated by $F h a-1, P g m-2$ and $P g m-3$. The relative spread of regional populations on these first two axes is greater than the spread of local populations, indicating greater genetic differentiation. Based on scores for canonical variable 1 , regional populations were split into two broad geographic groups. La Mauricie, Forillon, Fundy, Cape Breton and Kejimkujik in the east, all had negative scores for variable 1 , and Gatineau, Point Pelee and Pukaskwa in the west, all had positive scores. Georgian Bay was an exception to this geographic differentiation, grouping with the eastern populations on the first axis. On the second axis Kejimkujik and Point Pelee were separated from the other populations, however, by itself, canonical variable 2 accounted for only $13 \%$ of the total observed variation. Gene flow among regional populations was estimated as $N m=8.2$ (Table 4.3 ). Estimates of inter-population gene flow among local populations were approximately twice that, $N m=13.8$. Excluding any one population changed estimates of gene flow 
Table 4.3 Genetic differentiation and gene flow summary statistics for A. saccharum regional and local populations

\begin{tabular}{lll}
\hline & $\begin{array}{l}\text { Regional populations } \\
(n=9)\end{array}$ & $\begin{array}{l}\text { Local populations } \\
(n=8)\end{array}$ \\
\hline $\begin{array}{l}\text { Mean fixation coefficient } \\
\left(F_{\mathrm{s},}\right)\end{array}$ & 0.049 & 0.017 \\
$\begin{array}{l}\text { Mean Nei's minimum } \\
\text { genetic distance }\left(D_{\mathrm{m}}\right)\end{array}$ & $\begin{array}{l}0.007 \\
(0.002-0.130)\end{array}$ & $\begin{array}{l}0.002 \\
(0.001-0.004)\end{array}$ \\
$\begin{array}{l}\text { Number of migrants per } \\
\text { generation }(N m)^{*}\end{array}$ & 8.2 & 13.8 \\
\begin{tabular}{l} 
Number of private alleles \\
\hline
\end{tabular} & 8 & 13 \\
\hline
\end{tabular}

Notes: () range. * estimated using rare alleles method (Slatkin 1985; Slatkin \& Barton 1989). 


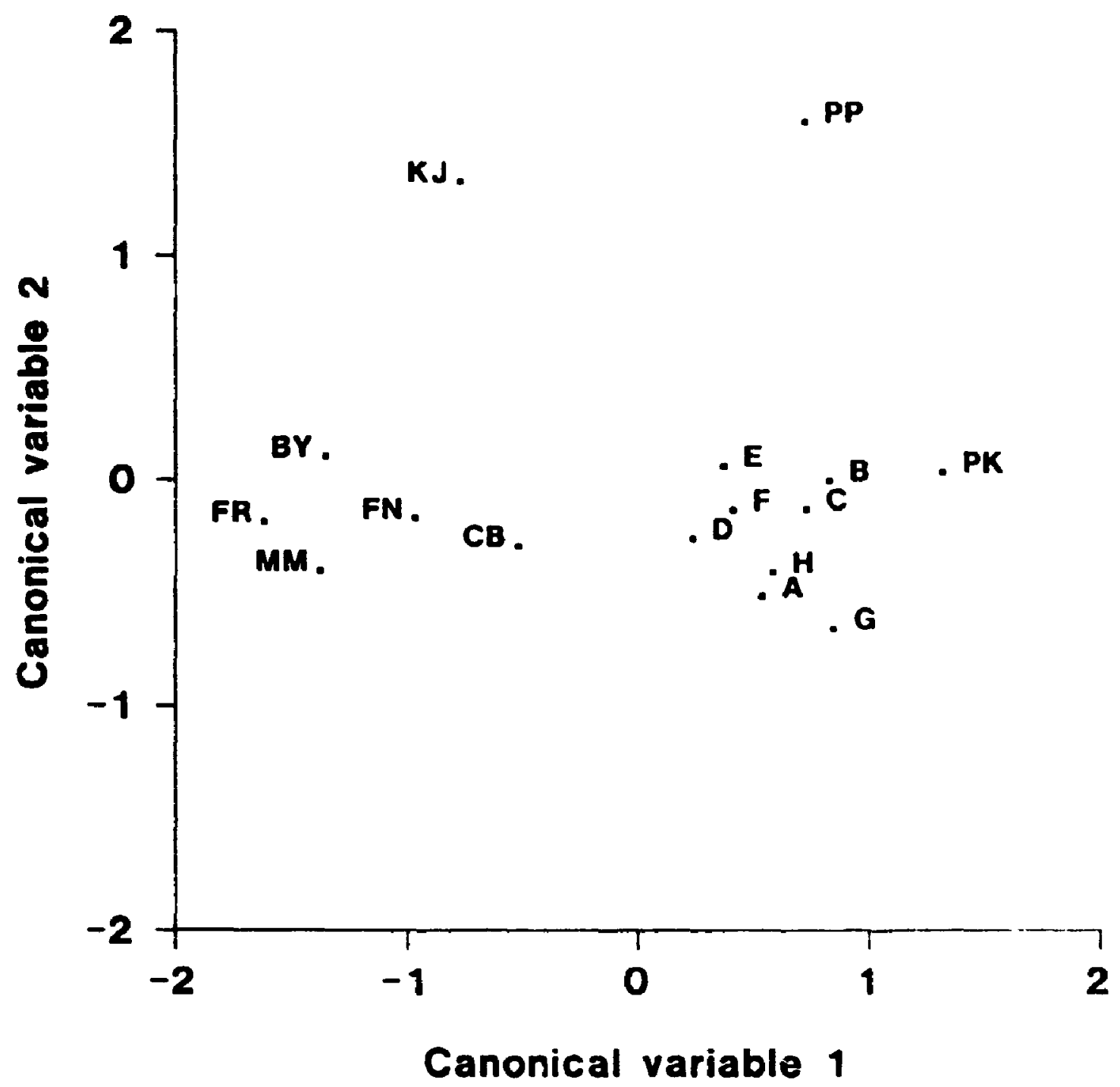

Figure 4.2 Distribition of regional and locial populations on the tirst iwo canonical axes.

Regional populations: CB: Cape Breton FN: Fundy FR: Forillon BY Cicorglan Bay A: Gatıneau KJ: Kejımkujk MM: Mauricte PK. Pukiskwa PP. Point Pelece lakial pepulations $A-H$. 
among resulting population subsets very little e.g. gene flow estimates for regional population subsets were $\mathrm{Nm}=8.2-10.5$ and for local population subsets $\mathrm{Nm}=10.5$ 13.8. This indicates that no one population contributed considerably more or less to among-population gene flow at either scale.

\section{DISCUSSION}

The amount of genetic variation $\left(A, H_{1}, P\right)$ observed within the nine regional populations of $A$. sactharum was similar to that found by Perry and Knowles (1989) for tive populations in northwestern Ontario using data from 11 allozyme loci. Ginetic variation was slightly lower than has been observed for other North American angiosperm trees and shrubs (e.g. Populus tremuloides Michx. (Hyun et al. 1987), Almus crispa (Ait.) Pursh (Bousquet et al. 1987), Almus rugosa (Du Roi) Sprengel (Bousquet et al. 1988)), though the range of inter-population differences in amount of variation was ccimparable. Genetic variation was generally lower than that found by Hamrick and Loveless (1989) for 16 tropical angiosperm trees and shrubs.

Differences in amount of genetic variation among regional populations, particularly differences in mean individual heterozygosity relative to polymorphism, probably reflect the action of different genetic processes. Cape Breton and Point Pelec were the two populations with the lowest levels of individual heterozygosity among the regional populations. Point Pelee was the smallest of all of the populations sampled, with no more than $\mathbf{5 0}$ sexually mature individuals. It had moderate polymorphism $(P=0.529)$, exhibited the highest population inbreeding coefficient 
$\left(F_{\mathrm{ts}}=0.156\right)$ and showed significant devidton from random mating. This suggests that the low observed heterozygosity in this population is the result of inbreding within a small population. The Cape Breton population was also small. with A. saccharum having a very restricted distribution within Cape Breton Highlands National Park. Cape Breton had the lowest heterozygosity of the regional poppulations but. in contrast with Point Peles, it also had very low polymorphism $(f=0.412)$, a moderate inbreeding coefficient $\left(F_{\mathrm{s}}=0.032\right)$ and showed no evidence of deviation from random mating. In this case it seems more likely that the low observed heterozygosity is a reflection of low overall population genetic variation. This is possibly the result of genetic drift and/or selection at the eastern limit of the species range.

The distribution of genetic variation among regional populations was similar to that observed for other outcrossing tree species, with a wide distribution of common alleles at various loci throughout the range (Hyun (' al. 1987). However the differences in population allele frequencies at 10 of the 1.3 polymorphic loci, indicate that inter-population differences in genetic composition exist. The overall fixalıon coefficient for regional populations $\left(F_{\mathrm{s}}=0.049\right)$ was higher than that previously observed for $A$. saccharum populations separated by up to $330 \mathrm{~km}\left(F_{\mathrm{st}}=0.03 .3\right)$ (Perry \& Knowles 1989). This represents moderate genetic differentiation compared with other angiosperm tree and shrub species with populations distributed over hundreds of kilometres e.g. Fagus syliarica L. (Comps at al. 1990), P. Iremuluides (Hyun et al. 1987), A. crispa (Bousquet et al. 1987) and A. rugosa (Bousquet (' al. 1988). The 
mean genetic distance among regional populations of $D_{\mathrm{m}}=0.007$ was also higher than that reported for $A$. saccharum by Prry \& Knowles (1989). The greater differentiation is probably the result of the larger geographical separation of regional populations in this study. This is supported by the weak positive correlation between genetic and geographic distance which is also in contrast with previous results for A. succhurum (Perry \& Knowles 1989) and suggests at least some isolation by distance across the species' range. Together these results suggest that the estimated level of inter-population gene flow at the regional scale $(\mathrm{Nm}=8.2)$ is not enough to prevent the accumulation of population differences in genetic composition. Such a level of inter-population gene flow is not dissimilar to the average observed by Hamrick \& Loveless (1989) for several tropical angiosperm trees and shrubs $(\mathrm{Nm}=5.38)$.

The two broad geographic groups of populations distinguished by the multivariate analysis provide evidence for a level of organisation of genetic variation within $A$. saccharum that is higher than the population. This may reflect the existence of two different selective regimes, possibly the high precipitation maritime climate of the east coast and the drier climate of the west (Ro :e 1977). Results of common garden experiments conducted by Kriebel (1957) provide some evidence for regional adaptation of $A$. succharum for characteristics such as drought resistance and sensitivity to leaf injury owing to high insolation. A second possibility is that the observed geographical structure of genetic variation reflects patterns of gene flow, specifically patterns of migration following the glacial periods of the late Pleistocene. 
Braun (1964) has suggested that as the ladurentide lee margin began to retreat some $13000-14000$ years ago (Dyke \& Prest 1987a: 19876), maple associations (including A. saccharum) migrated northuards by several routes. In the east. maple migrated north from Appalachian refugia, where an ice-free route to New Brunsush. Nowal Scotia and the Gaspé Peninsula existed as earlv as 12000 years ago (1)yeje d Prest 1987b). However, subsequent westward colonisation of ice-frea areas of Ontario and Québec would have been inhibited by the continuous water barrier provided by the Goldthwait and Champlain Seas and early Lake Ontario and Lake Eric, untıl Y (x(x)-4) 500 years ago (Occhietti 1989). In the west. Braun (1964) suggests that becch-maple associations migrated north and east from Pleistocene refugia in the Driftless region of lowa, as well as trom directly south of the retreating ice margin, and these migrations are the source of the beech-maple forests of southern (Ontario. If this migration scenario is correct, then these two $A$. saccharum gene pools, which maty have been isolated since the late Wisconsonian (23000 years ago), have only been in close proximity for at most the last 9000 years.

The lower tixation coefticient $\left(F_{\mathrm{st}}=0.017\right)$ and mean genetic distance $\left(D_{m}=0.002\right)$, and the lower number of loci exhibiting differences in allele frequencies, indicate that there were fewer differences in genetic composituon among local populations than among regional populations. These observations are similar (o) data from $\boldsymbol{P}$. radiata stands separated by similar distances within a forest (Moran et al. 1988). They also agree with data from a number of plant species summarised by Loveless \& Hamrick (1984), suggesting that the amount of genetic diversity among 
population subdivisions is about half that among populations. This level of local population differentiation is also consistent with Perry \& Knowles' (1989) genetic distance estimate between two populations of $A$. saccharum separated by less than $20 \mathrm{~km}$.

The reduced differentiation among local $A$. saccharum populations relative to regional populations in part reflects the higher gene flow among local populations $(N m=13.8)$ which would homogenise genetic composition and counteract random differentiation owing to drift. This would also account for the reduced range of within-population $(P)$ and within-individual $\left(H_{l}\right)$ variation observed among local populations. It may also be the result of local populations being subject to a similar selective regime. If this is the case, selection, which may act to differentiate populations across the species range in response to different regional environments, may be acting to homogenise local populations within the same environment.

Even at the local scale however, there was some genetic heterogeneity among populations as shown by differences in allele frequencies for loci $A a t-2, M d h p-2$, Pgm-2 and Pgm-4. Together with observed variation in mean population fixation indices, this suggests that while local populations are more genetically cohesive than regional populations, they are not panmictic. The weak positive correlation of genetic and geographic distances among local populations supports the contention that there is at least some level of restriction of gene flow among local populations.

The high total number of alleles found in the local populations compared to the regional populations may be a reflection of relative sampling intensity, as the more 
extensive sampling in Gatineau Park allowed the deteotmon of alleles with ireytuemes eight times lower than in any of the regiomal populatwons. If cilluncill is typtial, then this suggests that :he sampling conducted in other parts of the species range probably resulted in an underestimate of genetic vartation. A second pessibslity is that the high number of alleles observed in Gatineau is related to its central locition withun the geographic range of $A$. saccharum relative to the other regions simpled. Several studies of tree species have shown evidence of elevated genetic variation in the modele of the species' range relative to the margins e.g. Pinus rigida Mill. (Ciuries \& I.edig 1982). Picc'a glanca (Moench) Voss (Tremblay \& Simon 1989). P. me'nicivii (1.i \& Adams 1989).

As discussed in Chapter 2, three of the four local populations for which data were available (populations $\mathrm{A}, \mathrm{B}$ and $\mathrm{C}$ ), exhibited significint withı-peptulation spatial genetic structure, which may relate to the division of the population into breeding associations, possibly based on flowering time. Spatially these associations appear to extend beyond the confines of the lha sampling plot. As comparison of genetic variation among local populations show that at this next spattal scatce there is restriction of gene flow, the spatial scale of breeding associations is probably somewhere between the two scales examined.

Overall these results show that $A$. coccharum exhibits genctic structure at all of the three scales examined, among regional populations across the spectes range in Canada, among local populations withın a region and among ındividuals withın populations. While some of the processes which may be responsible for the observed 

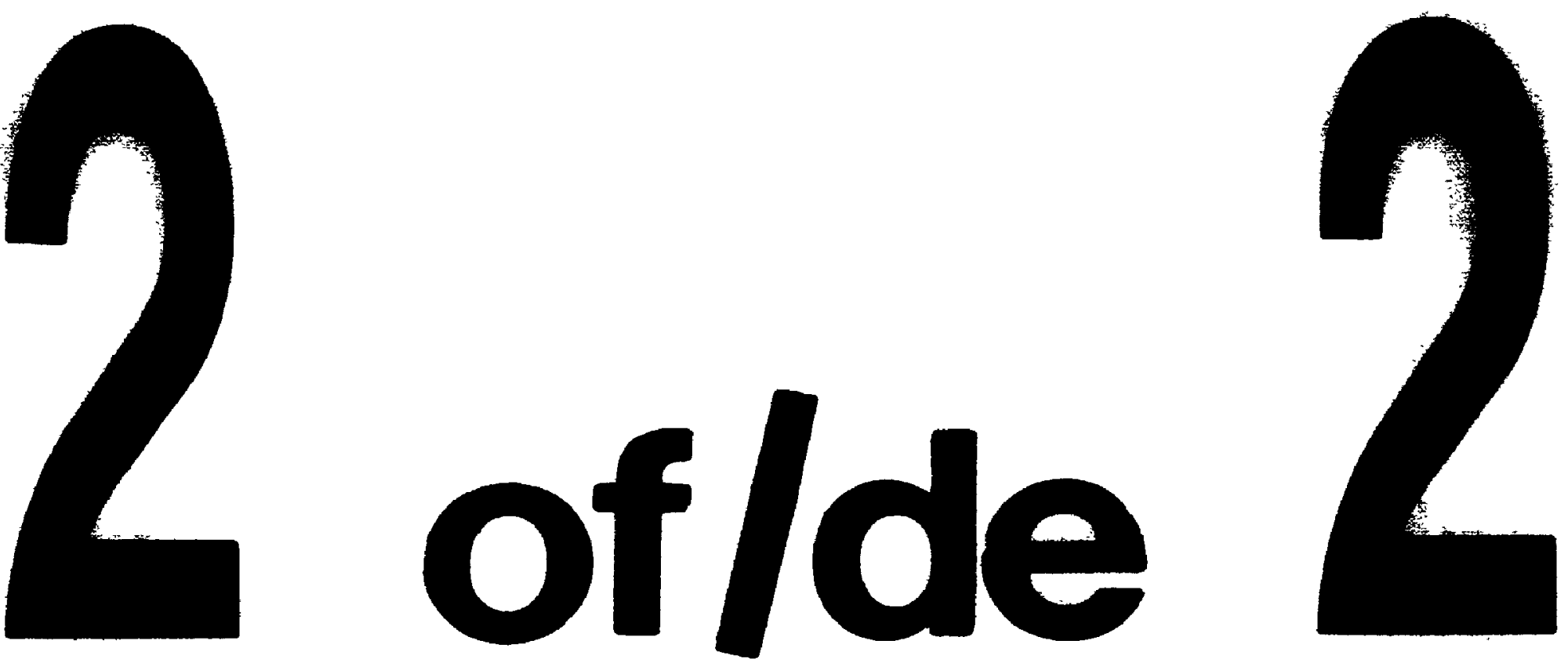

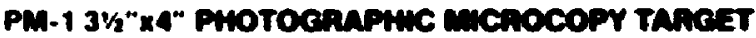
mas wiva Ansiriso w2 ecumalant

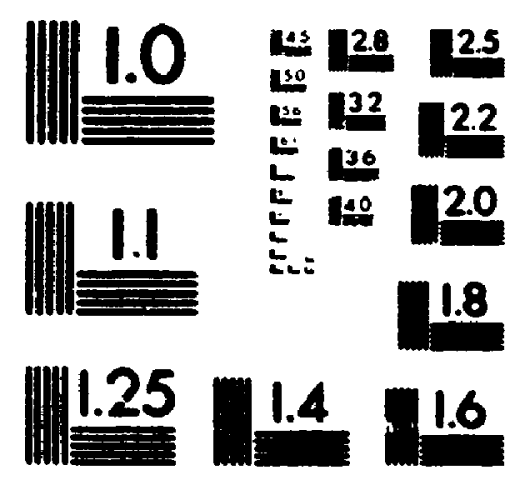


patterns of genetic variation probably operate at several scales ( $($... . selection), others are scale-specific and may have temporal and spatial dynamics as different as the hundreds of kilometres and thousands of years involved in post-glacial migrations. and the meters and days involved in flowering ecology. The genetic variation of any one individual may be seen as the result of the action of all of these processes layered upon each other in time and space. Given this information, any conservation strategy for A. saccharum should aim to maintain a spatial hierarchy of populations and individuals throughout the species' range. This approach should encompass that genetic variation already in existence, and provide the tange of spatial and organisational scales necessary for processes such as selection, gene flow and genetic drift to continue to operate. Certainly, the smallest population unit for conservation should be larger than the tha sample plots used here, which are probably not big enough to include the spatial scales of mating relationships that make $A$. saccharum breeding associations. 


\section{GENERAL DISCUSSION}

If the original assumption of this study is correct, i.e. that Acer saccharum populations in existing continuous forest are genetically representative of prefragmentation populations, then the results of the first three parts of this study (Chapters 1-3) indicate that forest fragmentation has affected the genetic variation and spatial genetic structure of $A$. saccharum populations and, therefore, presumably, the population genetic processes underlying these. However, these effects appear to have been more complex than has previously been suggested e.g. Saunders et al. (1991).

Comparisons of genetic variation in first-year seedling cohorts between forest patch and continuous forest populations clearly show that fragmentation has not led to an increase in genetic drift or inbreeding resulting in loss of within-population $(P, A)$ or within-individual $\left(H_{1}\right)$ genetic variation. Rather, results suggest that while the overall genetic variation of the fragmented forest system (patches populations) has been reduced, possibly owing to initial founder effects, on average, levels of withinpopulation and within-individual genetic variation in patches have increased slightly. Data on wind dispersal of pollen across pasture fields that separate forest patches, and comparisons of the distribution of several alleles among populations between patch and continuous forest populations, suggest that this may be the result of increased inter-population gene flow.

Spatial patterns of genetic similarity in first-year seedlings suggest that mating relationships within continuous forest populations are not spatially limited over the scales examined $(<141.4 \mathrm{~m})$, and that breeding associations, which may be 
determined by individual flowering tume. probably extend beyond the tha area sampled, though they may not include all reproductive individuals within it. As forest patches were often only slightly larger than this sampling area. they may not be large enough to encompass the spatial range of mating events occurring in 'normal' breeding associations. Negative genetic associations observed among seedlings from opposite edges of forest patches indicate that edge mating events may incorporate immigrant pollen pools with different allelic compositions. This supports the previous inter-patch gene flow hypothesis. Furthermore, the spatial mixing of genotypes at short ranges ir. patches has been reduced, possibly by increased isolation of seed shadows around reproductive trees, which generally have reduced densities in patch populations owing to tree cutting.

Finally, genetic variation and spatial genetic structure were very similar among the four developmentally based cohorts within the continuous forest population studied, indicating that, within this population, genetic variation and, importantly, spatial genetic structure, are probably determined before the first few weeks of seedling life. This eliminates a significant role for selection, except from tmbryos to seedlings, in determining genetic composition at this scale and again points to an important role for mating. It also suggests that within continuous populations mating relationships may exhibit a degree of temporal stability. Apparent reduced genetic cohesion among cohorts in the patch population, in terms of both amount of genetic variation and spatial genetic structure, therefore probably reflects changes in mating relationships owing to fragmentation as previously discussed. 
Based on these results it would appear that, apart from an initial loss of genetic variation, probably owing to founder effects at the time that the forest was cleared, the fundamental genetic effect of forest fragmentation has been a change in patterns of gene flow and mating relationships. Processes associated with fragmentation that have caused these changes probably include the replacement of the original forest between present patch populations with crops and pasture, and the cutting of reproductive individuals within patch populations. Changes in gene flow may range from reduced mixing of seed, generating positive genetic associations among seedlings at a scale of a few metres within patch popuiations, to increased pollen mediated gene flow among forest patches. The latter may be generating within-population genetic variation by extending the range of patch population breeding associations, which would otherwise probably be truncated owing to the sinall area of forest patches. Furthermore, not only has fragmentation affected the spatial component of patterns of gene flow, it may also have affected the temporal variability of mating relationships, as evidenced by the increased among-cohort differences in genetic variation and structure in patch populations.

Further manipulation of the data presented here cannot provide explicit tests of these hypotheses. However, there are lines of empirical investigation that may prove useful in determining the reality and generality of these ideas. Certainly, the use of more highly variable genetic markers, for example minisatellite DNA regions (Nybom 1990), which allow identification of individual parental contributions to progeny genotypes, provide potential for more detailed quantification of mating relationships 
among individuals. Comparison of these relationships over similar spatial scales in continuous and fragmented habitats should provide more information regarding the effects of habitat fragmentation on patterns and rates of inter-population and intra-population gene flow. Comparisons of patterns of genetic variation among pre-fragmentation and post-fragmentation cohorts, in more recently fragmented populations, may also indicate changes in patterns of inter-population gene flow, or amount of genetic variation within populations or individuals, resulting from fragmentation. Indeed, this approach has already been adopted by Foré $\mathrm{ef}$ al. (1992b). Extension of empirical comparative studies of allozyme variation in fragmented and continuous populations to other species, with varying life history traits (e.g. dispersal capabilities, longevity, reproductive strategy - sexual/asexual), should give some idea as to the generality of the effects of fragmentation indicated by this study. Similar results might well be expected for species with relatively high potential for gene flow, such as other wind pollinated trees, however, the effects of fragmentation on less mobile species may be more in line with expectations based on reduced population size and increased isolation.

It is difficult to assess the specific ecological or evolutionary implications of the type of disruption of patterns of gene flow suggested here as the effect of forest fragmentation on $A$. saccharum. Results from the final study (Chapter 4) suggest that A. saccharum exhibits genetic structure at four spatial scales over the distances examined which were up to $1873 \mathrm{~km}$. The scale of forest fragmentation addressed here is affecting patterns of genetic interactions at the lower two of these scales, 
among individuals within local populations, and among local populations within a region. Such changes may result in relatively simple effects for individuals, such as reduced fitness owing to outbreeding depression, because of the breakup of locally adaptive gene complexes. Redistribution of genetic variation at these scales may also influence the way that the species can respond to local changes in selective pressures at a population scale. The clear evidence of multiscale spatial genetic structure in A. saccharum suggests that any conservation strategy for this species must adopt a hierarchical approach, maintaining populations across the species range, as well as local populations within regions. The aim of this is both to encompass a large sample of the genetic variation existing within the species, and to maintain patterns and intensities of genetic interactions such that the genetic juxtaposition of individuals and breeding associations is not modified.

These results indicate that empirical comparative studies of genetic variation have the potential to contribute information about the effects of modification of natural populations, by identifying the effects of process changes. As well as identifying process changes that occur, more detailed empirical investigations may provide quantification of these changes, allowing their incorporation into more realistic, possibly species specific, population genetics models, for use in conservation management. 


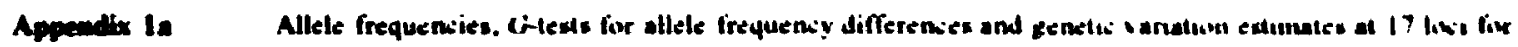
A. saccharum palich poppulations (a-h)

\begin{tabular}{|c|c|c|c|c|c|c|c|c|c|c|}
\hline \multirow[b]{2}{*}{ Loves } & \multirow{2}{*}{$\begin{array}{l}\text { Allek } \\
\text { (R) }\end{array}$} & \multicolumn{8}{|c|}{ Patis pulatums } & \multirow[t]{2}{*}{ (i-tent } \\
\hline & & $\bullet$ & h & $\therefore$ & $\mathbf{d}$ & 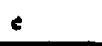 & $\mathbf{t}$ & $\varepsilon$ & h & \\
\hline \multirow[t]{4}{*}{ Adh-1 } & 0.355 & 0,000 & 0.000 & 0000 & 0.000 & 0000 & $\operatorname{los} \times(x)$ & $\log (n)$ & $n(x)$ & \\
\hline & 0.320 & 0.646 & 0.653 & 0.nat & 0.674 & 0750 & $0 \times 20$ & 0765 & 11746 & \\
\hline & 0.275 & 0.354 & 0.347 & 0.316 & 0.326 & 0250 & $n 180$ & 0.2 .15 & 0214 & \\
\hline & 0.250 & 0.000 & 0000 & $0.000 \mathrm{~s}$ & 0.000 & 0.000 & $0 .(x)$ & $n(x)$ & $0(x)$ & \\
\hline \multirow[t]{5}{*}{ Aar-? } & 0.400 & 0.022 & 0.021 & 0.000 & 0.023 & o oto & 0011 & 0035 & (1) (nn) & $\cdots$ \\
\hline & 0.350 & 0.000 & 0.000 & 0.000 & 0.000 & 0034 & $0 .(\operatorname{mon})$ & $0 \mathbf{0 0 0}$ & $\ln (x)$ & \\
\hline & 0.285 & 0.756 & 0.862 & 0.145 & 0.744 & 0.682 & 0033 & $11.8+4$ & 0.837 & \\
\hline & 0.170 & 0000 & 0021 & $0.04:$ & 0035 & 0.057 & 0.033 & 11.035 & 0010 & \\
\hline & 0.150 & 0.222 & 0.096 & 0.107 & $0.19 \%$ & 0.148 & 0.022 & $0.0 \times 1$ & 1) 153 & \\
\hline \multirow[t]{4}{*}{ Fba-1 } & 0.230 & 0000 & $0.0 \mathrm{~m}$ & $\therefore 4 \times 00$ & $0(00)$ & 0000 & (n.(m) & $11(x)$ & $0(x)=$ & $\bullet$ \\
\hline & 0.205 & 0.980 & 1000 & 0.920 & 1.000 & (I) 9N0) & $1.0 \times(x)$ & 096 & 10490 & \\
\hline & 0.185 & 0.020 & 0.000 & 0080 & $0.0 \times)$ & 0.020 & $11 .(0) \times 0$ & 01031 & 0030 & \\
\hline & 0.175 & 0.000 & 0.000 & 0.000 & 0.000 & 0.000 & $0(x)$ & $\mathbf{0 . 0 m}$ & $0(m x)$ & \\
\hline$C_{p i-1}$ & 0.565 & 1.000 & 1.000 & 1.000 & 1.000 & 1.000 & 1.1000 & $1 \mathbf{~ ( x )}$ & $I(x)$ & \\
\hline \multirow[t]{10}{*}{$C_{p i-2}$} & 0.450 & 0.000 & 0.000 & 0.000 & $0.0 \mathrm{X}$ & 0.0000 & 0.0000 & 11.0000 & $0(m)$ & $\bullet \bullet$ \\
\hline & 0.435 & 0.000 & 0.000 & 0.000 & 0.000 & 0.000 & U.(mo) & (1.000) & $0.6 \mathrm{MOO}$ & \\
\hline & 0.430 & 0.030 & 0.020 & 0030 & 0.020 & 0010 & 0.020 & 0.031 & $0(x \times)$ & \\
\hline & 0.425 & 0.000 & 0.000 & 0.000 & 0.000 & 0.010 & 0.000 & 0.000 & 0.000 & \\
\hline & 0.385 & 0.710 & 0.750 & 0.810 & 0.720 & 0.850 & 0.720 & 0.416 & O.850 & \\
\hline & 0.345 & 0.000 & 0.010 & 0.000 & 0.010 & 0.000 & 0.020 & 0.010 & 0.010 & \\
\hline & 0.335 & 0.110 & 0.040 & 0.050 & 0.170 & 0130 & 0.140 & 0112 & 0.000 & \\
\hline & 0.325 & 0.130 & 0.100 & 0.100 & 0.030 & 0.000 & 0.000 & 0010 & $0.0(n)$ & \\
\hline & 0.270 & 0.020 & 0.080 & 0.010 & 0.050 & 0.000 & 0.040 & 0020 & $n$ ond & \\
\hline & 0.255 & 0.000 & 0.000 & $0.0 \mathrm{~m}$ & 0.000 & 0.000 & 000 & 0000 & $n(m)$ & \\
\hline Capelh-1 & 0.340 & 1.000 & 1.000 & 1.000 & 1.000 & 1.000 & 1.0000 & 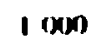 & $1 .(9 \times n)$ & \\
\hline \multirow[t]{2}{*}{ Gopalh-2 } & 0.275 & 0.760 & 0.850 & 0.870 & 0.830 & $n .840$ & $D(x)$ & 0.1467 & $0 \$ 20$ & \\
\hline & 0.220 & 0.240 & 0.150 & 01.30 & 0.170 & 0160 & 0100 & 0.133 & 0.1801 & \\
\hline Mdh-1 & 0.155 & 1.000 & 1.000 & 1.000 & 1000 & 1.0000 & 1000 & $1.000)$ & $\ln (x)$ & \\
\hline \multirow[t]{2}{*}{ MAh-2 } & 0.120 & 1.000 & 1.000 & 1.000 & 1.000 & 1000 & 1.000 & 1000 & $I .0 m)$ & \\
\hline & 0.065 & 0.000 & 0.000 & 0000 & 0.000 & 0.000 & 0.000 & $\|(x)$ & 0000 & \\
\hline MUhp-1 & 0.420 & 1.000 & 1.000 & 1.000 & 1.000 & 1000 & 1.000 & 1.000 & $1 \mathrm{nmon}$ & \\
\hline
\end{tabular}




\begin{tabular}{|c|c|c|c|c|c|c|c|c|c|c|}
\hline Lxux & $\left(R_{v}\right)$ & 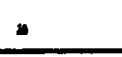 & b & $=$ & 1 & $c$ & $f$ & $E$ & $n$ & Gren \\
\hline \multirow[t]{4}{*}{ Malhp.2 } & 1) 300 & 1) 293 & $03 \times 5$ & 0 337 & 0.276 & 0.260 & 0.319 & 0.319 & 0.300 & \\
\hline & 0270 & 0) 663 & 0.5113 & 0622 & 0.724 & 0690 & 0638 & 0.628 & 0.670 & \\
\hline & 0230 & 0011 & 0.031 & 0041 & 0.000 & 0.050 & 0.043 & 0.053 & 0.030 & \\
\hline & $02(x)$ & 033 & 0.000 & 0.000 & 0.000 & 0.000 & 0.000 & 0.000 & 0.000 & \\
\hline \multirow[t]{3}{*}{$P_{X m-1}$} & 0.441 & 0.010 & 0000 & 0.000 & 0.000 & 0.041 & 0.031 & 0.000 & 0.033 & $\infty$ \\
\hline & 0.410 & 0.969 & 1.000 & 1.000 & 1.000 & 0.959 & 0.949 & 1.000 & 0.967 & \\
\hline & 0.390 & 0.021 & 0.000 & 0000 & 0.000 & 0.000 & 0.020 & 0.000 & 0.000 & \\
\hline \multirow[t]{7}{*}{$P_{x m m-2}$} & 0.410 & 0.092 & 0.040 & 0.050 & 0.110 & 0.031 & 0.020 & 0.010 & 0.030 & $\infty$ \\
\hline & () 390 & 0.000 & 0.000 & 0.000 & 0.000 & 0.041 & 0.000 & 0.000 & 0.000 & \\
\hline & o 375 & $0 \times 27$ & $0 \$ 70$ & 0.900 & 0.870 & 0.878 & 0.800 & 0.969 & 0.950 & \\
\hline & 0.325 & 0.031 & 0.020 & 0.010 & 0.000 & 0.010 & 0.060 & 0.010 & 0.010 & \\
\hline & 0.320 & 0.000 & 0.000 & 0.000 & 0.000 & 0.000 & 0.000 & 0.000 & 0.000 & \\
\hline & 0.315 & 0.051 & 0.070 & 0.040 & 0.020 & 0.041 & 0.120 & 0.010 & 0.000 & \\
\hline & 0310 & 0000 & 0.000 & 0.000 & 0.000 & 0.000 & 0.000 & 0.000 & 0.000 & \\
\hline \multirow[t]{3}{*}{$P_{x m-3}$} & ( 235 & 0.000 & 0.010 & 0.000 & 0.010 & 0.000 & 0.000 & 0.000 & 0.000 & \\
\hline & 0.205 & 0.480 & 0.990 & 0.980 & 0.979 & 1.000 & 0.990 & $0.9 \% 0$ & 0.990 & \\
\hline & 0.170 & 0.020 & 0.000 & 0.020 & 0.010 & 0.000 & 0.010 & 0.010 & 0.010 & \\
\hline \multirow[t]{5}{*}{ Prom-4 } & 0145 & 0020 & 0.000 & 0.000 & 0.000 & 0.000 & 0.000 & 0.000 & 0.000 & $\bullet$ \\
\hline & 0.170 & 0.959 & 1.000 & 0.979 & 0.950 & 0.990 & 0.990 & 0.969 & 0.960 & \\
\hline & 0 1s5 & 0.000 & 0.000 & 0.000 & 0.013 & 0.010 & 0.010 & 0.000 & 0.020 & \\
\hline & 0.140 & 0.000 & 0.000 & 0.021 & 0.038 & 0.000 & 0.000 & 0.000 & 0.020 & \\
\hline & 0.135 & 0.020 & 0.000 & 0.000 & 0.000 & 0.000 & 0.000 & 0.031 & 0.000 & \\
\hline \multirow[t]{3}{*}{$T_{p-1}$} & 0.610 & 0.020 & 0.000 & 0.000 & 0.000 & 0.000 & 0.000 & 0.000 & 0.000 & \\
\hline & 0.560 & 0.969 & 0.990 & 0.980 & 0.959 & 0.970 & 0.950 & 0.959 & 0.990 & \\
\hline & 0.470 & 0.031 & 0.010 & 0.020 & 0.041 & 0.030 & 0.050 & 0.041 & 0.010 & \\
\hline \multirow[t]{2}{*}{$T p i \cdot 2$} & 0.430 & 1.000 & 1.000 & 1.000 & 0.990 & 1.000 & $\$ .000$ & 1.000 & 1.000 & \\
\hline & 0.325 & 0.000 & 0.000 & 0.000 & 0.010 & 0.000 & 0.000 & 0.000 & 0.000 & \\
\hline \multicolumn{2}{|c|}{ Number of alleles } & 38 & 34 & 34 & 36 & 36 & 37 & 36 & 34 & \\
\hline \multicolumn{2}{|c|}{ Pulymowhiem (P) } & 0.647 & 0.471 & 0.588 & 0.588 & 0.588 & 0.388 & $0.5 e 8$ & 0.647 & \\
\hline \multicolumn{2}{|c|}{$\begin{array}{l}\text { Mean allelic diversity } \\
\text { (d) }\end{array}$} & $\begin{array}{l}2.24 \\
(0.31)\end{array}$ & $\begin{array}{l}2.00 \\
(0.35)\end{array}$ & $\begin{array}{l}2.00 \\
(0.28)\end{array}$ & $\begin{array}{l}2.12 \\
(0.33)\end{array}$ & $\begin{array}{l}2.12 \\
(0.33)\end{array}$ & $\begin{array}{l}2.18 \\
(0.33)\end{array}$ & $\begin{array}{l}2.12 \\
(0.34)\end{array}$ & $\begin{array}{l}2.00 \\
(0.23)\end{array}$ & \\
\hline \multicolumn{2}{|c|}{$\begin{array}{l}\text { Mean individual } \\
\text { helerueyseviny }\left(H_{1}\right)\end{array}$} & $\begin{array}{l}0.154 \\
(0.011)\end{array}$ & $\begin{array}{l}0.125 \\
(0.010)\end{array}$ & $\begin{array}{l}0.118 \\
(0.010)\end{array}$ & $\begin{array}{l}0.132 \\
(0.011)\end{array}$ & $\begin{array}{l}0.130 \\
(0.010)\end{array}$ & $\begin{array}{l}0.101 \\
(0.010)\end{array}$ & $\begin{array}{l}0.115 \\
(0.009)\end{array}$ & $\begin{array}{l}0.104 \\
(0.009)\end{array}$ & \\
\hline \multicolumn{2}{|c|}{ Mean sumple size } & $\begin{array}{l}48.9 \\
(0.4)\end{array}$ & $\begin{array}{l}49.9 \\
(0.3)\end{array}$ & $\begin{array}{l}493 \\
(0.5)\end{array}$ & $\begin{array}{l}48.4 \\
(0.7\end{array}$ & $\begin{array}{l}49.5 \\
(0.4)\end{array}$ & $\begin{array}{l}49.4 \\
(0.3)\end{array}$ & $\begin{array}{l}48.5 \\
(0.4)\end{array}$ & $\begin{array}{l}49.6 \\
(0.2)\end{array}$ & \\
\hline
\end{tabular}

Noves. (1) stemdand emor. Difterence in allele frequencies "* $p<0.01 *+p<0.001$. 


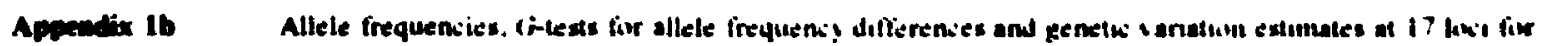
A. saccharum contrul pupulatuns $(A \cdot H)$

\begin{tabular}{|c|c|c|c|c|c|c|c|c|c|c|}
\hline \multirow[b]{2}{*}{ Locus: } & \multirow{2}{*}{$\begin{array}{l}\text { Allele } \\
\left(\boldsymbol{R}_{1}\right)\end{array}$} & \multicolumn{8}{|c|}{ Comanil perpulatiouns } & \multirow[t]{2}{*}{ (i-ted } \\
\hline & & A & $\mathbf{B}$ & $c$ & $\mathbf{D}$ & $\mathbf{E}$ & $\mathbf{F}$ & $\mathbf{G}$ & $\mathbf{H}$ & \\
\hline \multirow[t]{4}{*}{$A d h-1$} & 0.355 & 0.000 & 0.000 & $0.0 \times n$ & 000 & $0.00(\mathrm{n})$ & 00110 & anni & $1)(x x)$ & \\
\hline & 0.320 & 0.765 & 0.800 & 0.750 & 0.760 & 0.750 & 0.801 & 0.741 & 1755 & \\
\hline & 0.275 & 0.239 & 0.200 & 0290 & 0.240 & $(1250$ & 0180 & $(0.261)$ & 1.245 & \\
\hline & 0.250 & 0.000 & 0.000 & 0.000 & 0000 & $0.0(x)$ & 00110 & o (nn) & $0.0 \times 10$ & \\
\hline \multirow[t]{5}{*}{ Aat-2 } & 0.400 & 0.020 & 0.011 & 0.011 & 0036 & $0.0 \times 0$ & $0 .(\mathbf{k x})$ & $0 .(1 \times n)$ & n won & $\cdots$ \\
\hline & 0.350 & 0.000 & 0.011 & 0.000 & 0.000 & 0.000 & $0(x)$ & $0(\mathrm{mM})$ & 0.000 & \\
\hline & 0.285 & 0.745 & 0.875 & 0.837 & 0.893 & 0.770 & 0.854 & 0875 & $0 . n+1$ & \\
\hline & 0.170 & 0.000 & 0.023 & 0.000 & 0.000 & 0.020 & 0026 & $0(m)$ & $11 \cos x$ & \\
\hline & 0.150 & 0.235 & 0.080 & 0.152 & 0.071 & 0.210 & 0115 & 0125 & 10150 & \\
\hline \multirow[t]{4}{*}{ Fba-1 } & 0.230 & 0.000 & 0.000 & 0.000 & 0.000 & 0.000 & $0(x)$ & otano & 0.010 & \\
\hline & 0.205 & 1.000 & 1.000 & 1.000 & 1.000 & I (x) & () $4(9)$ & $1 .(x)$ & 1040 & \\
\hline & 0.185 & 0.000 & 0.000 & 0.000 & 0.000 & 11.000 & $0.1 \times 10$ & 0.000 & $0.00 \times)$ & \\
\hline & 0.175 & 0.000 & 0.000 & 0.000 & 0.000 & $0.0 \times n$ & 0.010 & 0.000 & $0(x) 0$ & \\
\hline$G p i-1$ & 0.565 & 1.000 & 1.000 & 1.000 & 1.000 & $1.0 \mathrm{mo}$ & 1.000 & I. (mx) & $(\mathbf{m x})$ & \\
\hline \multirow[t]{10}{*}{ Gpi-2 } & 0.450 & 0.000 & 0.000 & 0.000 & 0.000 & $0.00 \times)$ & 0.030 & $0(\mathbf{x} x)$ & 0.000 & \\
\hline & 0.435 & 0.000 & 0.000 & 0.000 & 0.000 & $0 \mathbf{0 0 0}$ & 0010 & 01010 & $0(x)$ & \\
\hline & 0.430 & 0.060 & 0.010 & 0.020 & 0030 & 0.070 & $0(60)$ & 0050 & 0.030 & \\
\hline & 0.425 & 0.000 & 0.000 & 0.000 & 0.000 & $00 \times 0$ & 0.000 & $0 \mathrm{cmo}$ & 0.0000 & \\
\hline & 0.385 & 0.790 & 0.830 & 0.790 & 0.830 & 0.820 & 0710 & 0760 & $0.7 \mathrm{m0}$ & \\
\hline & 0.345 & 0.010 & 0.000 & 0.010 & 0.020 & 0.000 & 0.000 & $0.0 \mathrm{mo}$ & $0 . \mathrm{mm}$ & \\
\hline & 0.335 & 0.060 & 0.100 & 0.100 & 0.090 & 0.070 & 0.010 & $00 \times$ & 0.050 & \\
\hline & 0.325 & 0.010 & 0.010 & 0.000 & 0.000 & 0.020 & 0.030 & 0050 & 0.070 & \\
\hline & 0.270 & 0.070 & 0.050 & 0.080 & 0.030 & 0.020 & 0070 & 1) 020 & $0(x)$ & \\
\hline & 0.255 & 0.000 & 0.000 & 0.000 & 0.000 & 0.000 & 0.010 & 0010 & 0000 & \\
\hline Gaph-1 & 0.340 & 1.000 & 1.000 & 1.000 & 1.000 & 1.000 & $1 \mathrm{~m}$ & $:(M x)$ & $\ln (x) 0$ & \\
\hline \multirow[t]{2}{*}{ Gepath-2 } & 0.275 & 0.810 & 0.880 & 0.930 & 0.900 & 0930 & $(1,6+6)$ & 0.831) & 0420 & \\
\hline & 0.220 & 0.190 & 0.120 & 0.070 & 0.100 & 0070 & 0160 & 0170 & 0.000 & \\
\hline$M M_{h-1}$ & 0.155 & 1.000 & 1.0000 & 1.000 & 1.000 & 1.000 & 1.000 & $1 \mathrm{mon}$ & $\operatorname{lo}(x)$ & \\
\hline \multirow[t]{2}{*}{ Men-2 } & 0.120 & 0.990 & 1.000 & 1.000 & 1.000 & 1.000 & 1.000 & 1.000 & 1000 & \\
\hline & 0.065 & 0.010 & 0.000 & 0.000 & 0.000 & 0.000 & 0.000 & $n(x)$ & $0 \mathrm{mon}$ & \\
\hline MAlp-1 & 0.420 & 1.000 & 1.000 & 1.000 & 1.000 & 1000 & 1.000 & 1 mon & $1 \mathbf{0 x 0}$ & (cent \\
\hline
\end{tabular}




\begin{tabular}{|c|c|c|c|c|c|c|c|c|c|c|}
\hline Limux & $(R)$, & $A$ & $\mathbf{B}$ & C & D & $E$ & $\mathbf{F}$ & G & $\mathbf{H}$ & G-2en \\
\hline \multirow[t]{4}{*}{ Mdhp 2} & 1) 300 & 11204 & 0243 & 11234 & 0337 & 0290 & 0.195 & 0411 & 0.327 & $\infty$ \\
\hline & 027 & 0735 & 0674 & 0.766 & 0531 & 0680 & 0.683 & 0.589 & 0.653 & \\
\hline & 1) 230 & $00 \times 1$ & c) 1333 & $0(0)$ & 0.133 & 0.030 & 0.110 & 0.000 & 0.020 & \\
\hline & $02(10)$ & 0000 & $00 \times 0$ & 0000 & 0.000 & 0.000 & 0.012 & 0000 & 0.000 & \\
\hline \multirow[t]{3}{*}{$P_{x m \cdot 1}$} & 0440 & $0(x)$ & $00(0)$ & n.mon & 0.020 & 0.000 & 0.010 & 0.021 & 0.020 & \\
\hline & 0.410 & 1.000 & $1.000)$ & 1.000 & 0.980 & 1.000 & 0.990 & 0.957 & 0.980 & \\
\hline & $0.391)$ & $0(x \times)$ & 0.000 & 0000 & 0.000 & 0.000 & 0.000 & 0.021 & 0.000 & \\
\hline \multirow[t]{7}{*}{$P_{x n+2}$} & 0.410 & 0.100 & 0051 & 0.082 & 0.090 & 0.000 & 0.031 & 0.042 & 0.000 & $\omega$ \\
\hline & 0.399 & 0.0000 & 0000 & 0.000 & 0.010 & 0.000 & 0.000 & 0.000 & 0.000 & \\
\hline & 0375 & $0 \times 4 n$ & 0.786 & 0.898 & 0.850 & 0.930 & 0.898 & 0.844 & 0.950 & \\
\hline & 0.32 .5 & 0.010 & 0.000 & 0000 & 0.000 & 0.050 & 0.020 & 0.073 & 0.040 & \\
\hline & 0.320 & 0.000 & 0000 & 0.000 & 0.000 & 0.010 & 0.000 & 0.000 & 0.000 & \\
\hline & 0315 & 0.010 & 0163 & 0.030 & 0.050 & 0.010 & 0.051 & 0.031 & 0.010 & \\
\hline & 0.310 & 0.000 & 0.000 & 0.000 & 0.000 & 0.000 & 0.000 & 0.010 & 0.000 & \\
\hline \multirow[t]{3}{*}{ Prm-3 } & 0.235 & 0.000 & 0.020 & 0.000 & 0.010 & 0.030 & 0.000 & 0.000 & 0.010 & \\
\hline & $0.20 \mathrm{~s}$ & 0.980 & 0970 & 0.980 & 0.950 & 0.970 & 1.000 & 0.978 & 0.990 & \\
\hline & 0170 & 0.020 & 0.010 & 0.020 & 0.040 & 0.000 & 0.000 & 0.022 & 0.000 & \\
\hline \multirow[t]{5}{*}{ Pgm-4 } & 0 IAs & 0.000 & 0.000 & 0.000 & 0.000 & 0.000 & 0.053 & 0.023 & 0.000 & 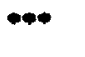 \\
\hline & 0170 & 0.990 & 0.960 & 0.969 & 1.000 & 1.000 & 0.894 & 0.955 & 0.980 & \\
\hline & 0.155 & 0.000 & $0.00)$ & 0.000 & 0.000 & 0.000 & 0.000 & 0.011 & 0.020 & \\
\hline & $0.1+0$ & 0.010 & 0.040 & 0.031 & 0.000 & 0.000 & 0.053 & 0.000 & 0.000 & \\
\hline & 0135 & tow & 0.000 & 0.000 & 0.000 & 0.000 & 0.000 & 0.011 & 0.000 & \\
\hline \multirow[t]{3}{*}{$T p m-1$} & 0.610 & $0 \mathrm{~cm}$ & 0.000 & 0.000 & 0.000 & 0.000 & 0.000 & 0.000 & 0.000 & \\
\hline & 0560 & 1.000 & 1.000 & 0.940 & 0.960 & 0.980 & 0.960 & 0.980 & 1.000 & \\
\hline & 0.470 & 0.000 & 0.000 & 0.060 & 0.040 & 0.020 & 0.040 & 0.020 & 0.100 & \\
\hline \multirow[t]{2}{*}{$T_{m} \cdot ?$} & 0.430 & 1000 & 1.500 & 1.000 & 1.000 & 1.000 & 1.000 & 1.000 & 1.000 & \\
\hline & 0.325 & 0.000 & 0.000 & 0.000 & 0.000 & 0.000 & 0.000 & 0.000 & 0.000 & \\
\hline \multicolumn{2}{|c|}{ Number of alleles } & 34 & 34 & 31 & 34 & 32 & 41 & 38 & 32 & \\
\hline \multicolumn{2}{|c|}{ Polymnrjhism (P) } & 0.529 & 0.471 & 0.529 & 0.529 & 0.471 & 0.588 & 0.588 & 0.588 & \\
\hline \multicolumn{2}{|c|}{$\begin{array}{l}\text { Mean altelic diveraly } \\
\text { (.1) }\end{array}$} & $\begin{array}{l}2.00 \\
(0.33)\end{array}$ & $\begin{array}{l}2.00 \\
(0.33)\end{array}$ & $\begin{array}{l}1.82 \\
(0.26)\end{array}$ & $\begin{array}{l}2.00 \\
(0.30)\end{array}$ & $\begin{array}{l}1.88 \\
(0.30)\end{array}$ & $\begin{array}{l}2.41 \\
(0.45)\end{array}$ & $\begin{array}{l}2.24 \\
(0.41)\end{array}$ & $\begin{array}{l}1.88 \\
(0.26)\end{array}$ & \\
\hline \multicolumn{2}{|c|}{$\begin{array}{l}\text { Mean individuat } \\
\text { heleriosygevaly }\left(H_{1}\right)\end{array}$} & $\begin{array}{l}0.120 \\
(0012)\end{array}$ & $\begin{array}{l}0.094 \\
(0(009)\end{array}$ & $\begin{array}{l}0.099 \\
(0.009)\end{array}$ & $\begin{array}{l}0.120 \\
(0.010)\end{array}$ & $\begin{array}{l}0.108 \\
(0.009)\end{array}$ & $\begin{array}{l}0.119 \\
(0.010)\end{array}$ & $\begin{array}{l}0.107 \\
(0.009)\end{array}$ & $\begin{array}{l}0.109 \\
(0.010)\end{array}$ & \\
\hline \multicolumn{2}{|c|}{ Mean sample size } & $\begin{array}{l}49.6 \\
(0.2)\end{array}$ & $\begin{array}{l}4.9 \\
(0.5)\end{array}$ & $\begin{array}{l}49.3 \\
(0.3)\end{array}$ & $\begin{array}{l}49.1 \\
(0.3)\end{array}$ & $\begin{array}{l}49.9 \\
(0.1)\end{array}$ & $\begin{array}{l}48.3 \\
(0.8)\end{array}$ & $\begin{array}{l}4.3 \\
(0.5)\end{array}$ & $\begin{array}{l}49.3 \\
(0.4)\end{array}$ & \\
\hline
\end{tabular}

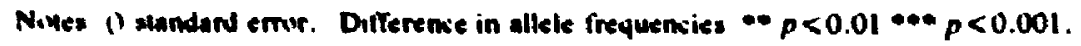




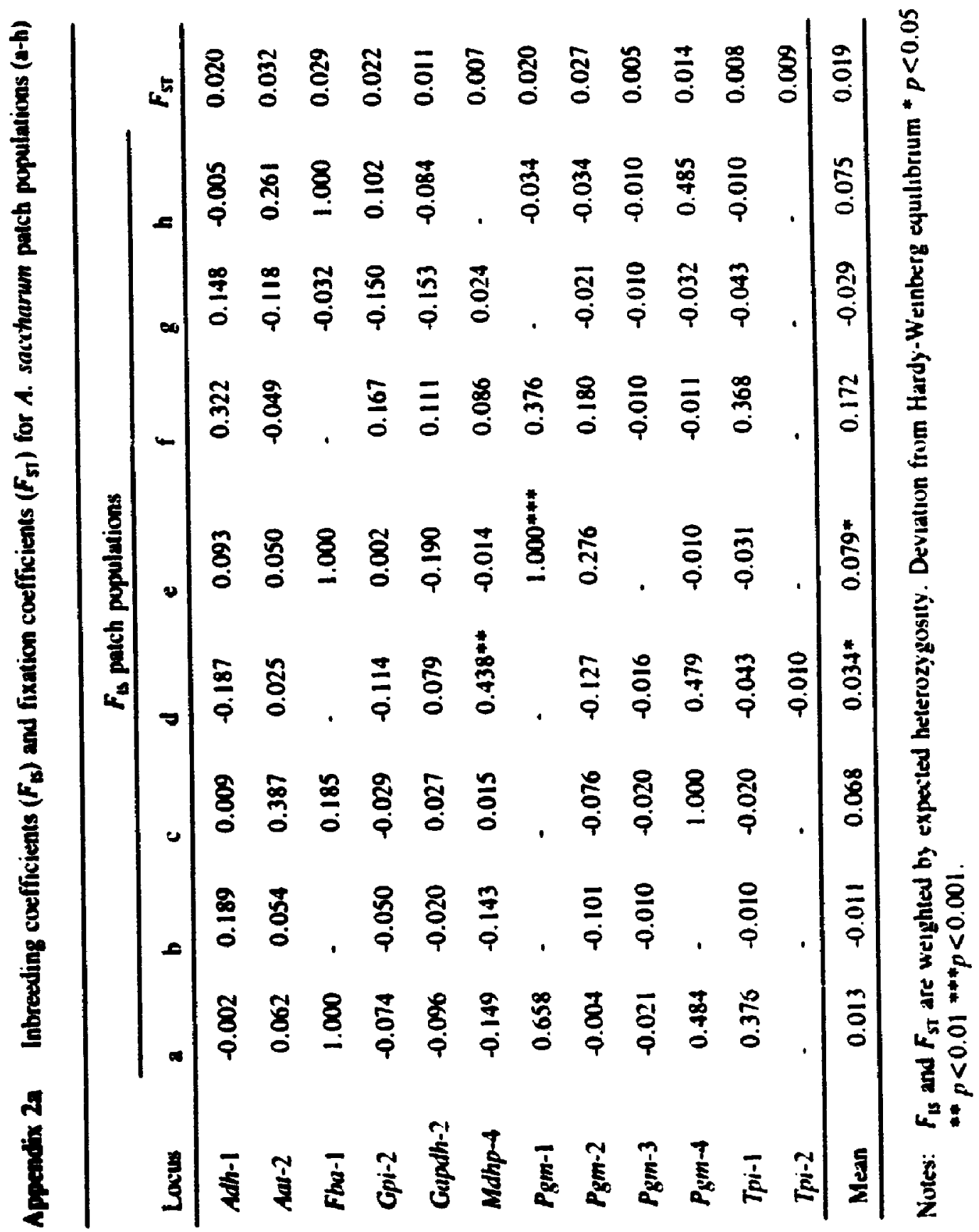




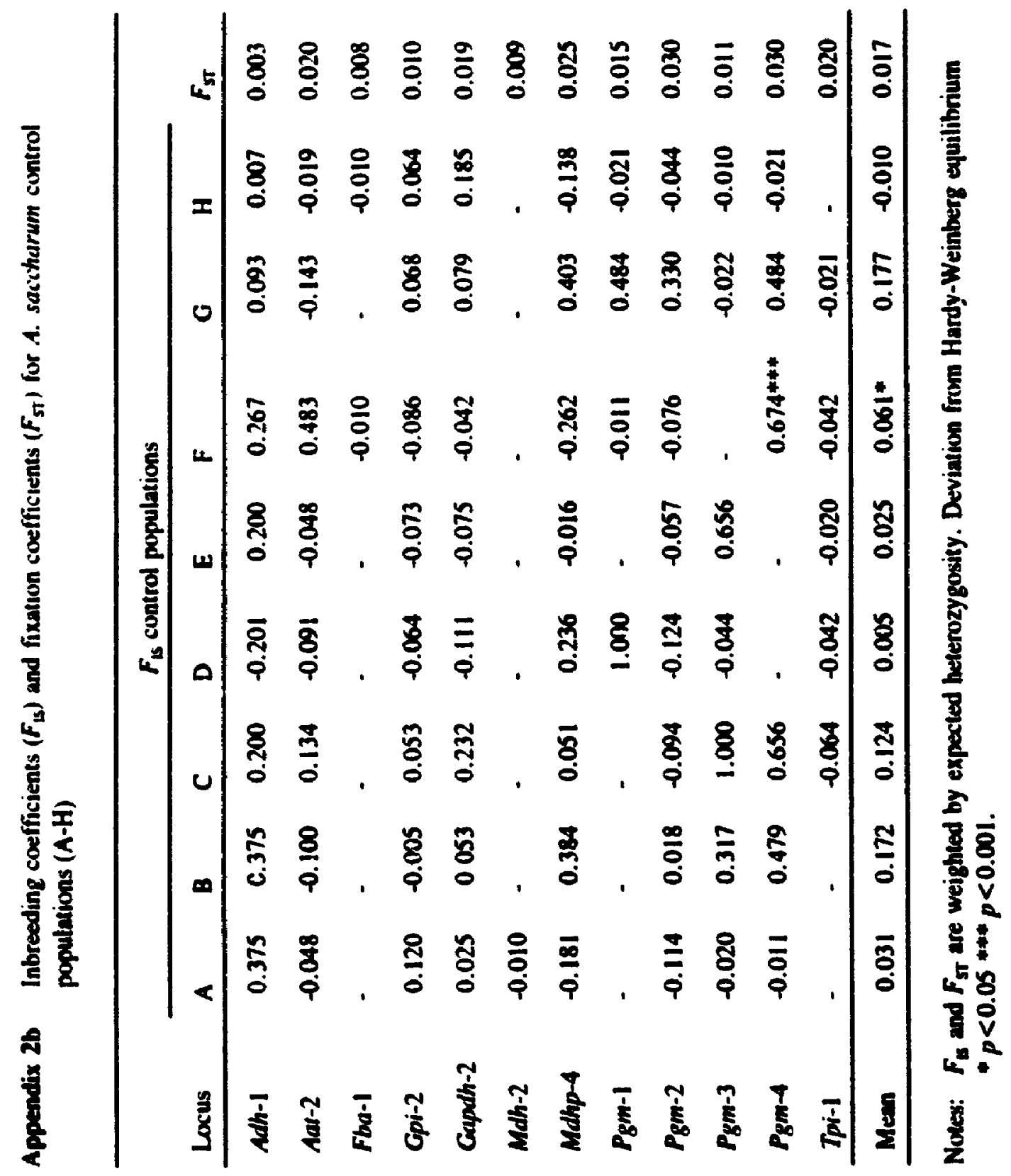


Appendix 3 Calculations for Moran's I spatial alltexorrelation coefficient for noninal data under the randomisation assumption following (liff $\&$ Ord (1981)

Moran's / statistic:

$$
I=n \sum_{j} w_{i} z_{i} z_{j} / \sum_{n}^{n} \sum_{i=i}^{n}
$$

Expected Moran's I:

$$
E(I)=-(n-1)^{-1}
$$

Variance of Moran's I:

$$
\begin{aligned}
& \sigma^{2}(E(I))=\left(n\left[\left(n^{2}-3 n+3\right) s_{1}-n s_{2}+3 s_{n}^{2}\right]-b_{i}\left[\left(n^{2}-n\right) s_{1}-2 n s_{2}+6 s_{11}=1\right.\right. \\
& \left.(n-1)[(n-2)(n-3)] s_{n}^{2}\right)-(n-1) !
\end{aligned}
$$

Standard normal deviate:

$$
C=|I-E(I)| / \sigma(E(I))
$$

where:

$n=$ number of observations

$w_{i j}=$ weighting given to the $i j$ th comparison, which is 1 when the $i$ th and $j$ th individuals are separated by the distance class for which $l$ is being calculated and $\|$ otherwise.

$$
z_{i}=x_{i}-\bar{x} \quad \text { (where in this case } \bar{x}=p \text { the popul. in allele frequency) }
$$


and where:

$$
\begin{aligned}
& S_{11}=\sum_{y} w_{4} \\
& s_{1}=0.5 \sum_{4}\left(w_{y}+w_{11}\right)^{2} \\
& s_{2}=\sum_{i=1}^{n}\left(\sum_{i=1}^{n} w_{y}+\sum_{i=1}^{n} w_{u}\right)= \\
& b_{2}=\sum_{z}^{n} /\left(\sum_{i}^{n} z^{*}=\right.
\end{aligned}
$$


47

Appendix 4 Calculations for nearest neighbour analysis following Clark \& Evans (1954) and using Donnelly's (1978) corrections for finite populations

Expected distance to nearest neighbour:

$$
r_{\mathrm{E}}=0.5 \sqrt{(\mathrm{A} / \mathrm{N})}+0.0514 P / N+0.041 P / N^{3}:
$$

Standard error of expected distance to nearest neighbour:

$$
\sigma\left(r_{E}\right)=0.0703 A / N^{2}+0.037 P \sqrt{\left(A / N^{3}\right)}
$$

Standard normal deviate:

$$
C=\left|r_{A}-r_{E}\right| / \sigma\left(r_{E}\right)
$$

where:

$A=$ sample area

$N=$ number of observations

$P=$ length of perimeter of sample area 


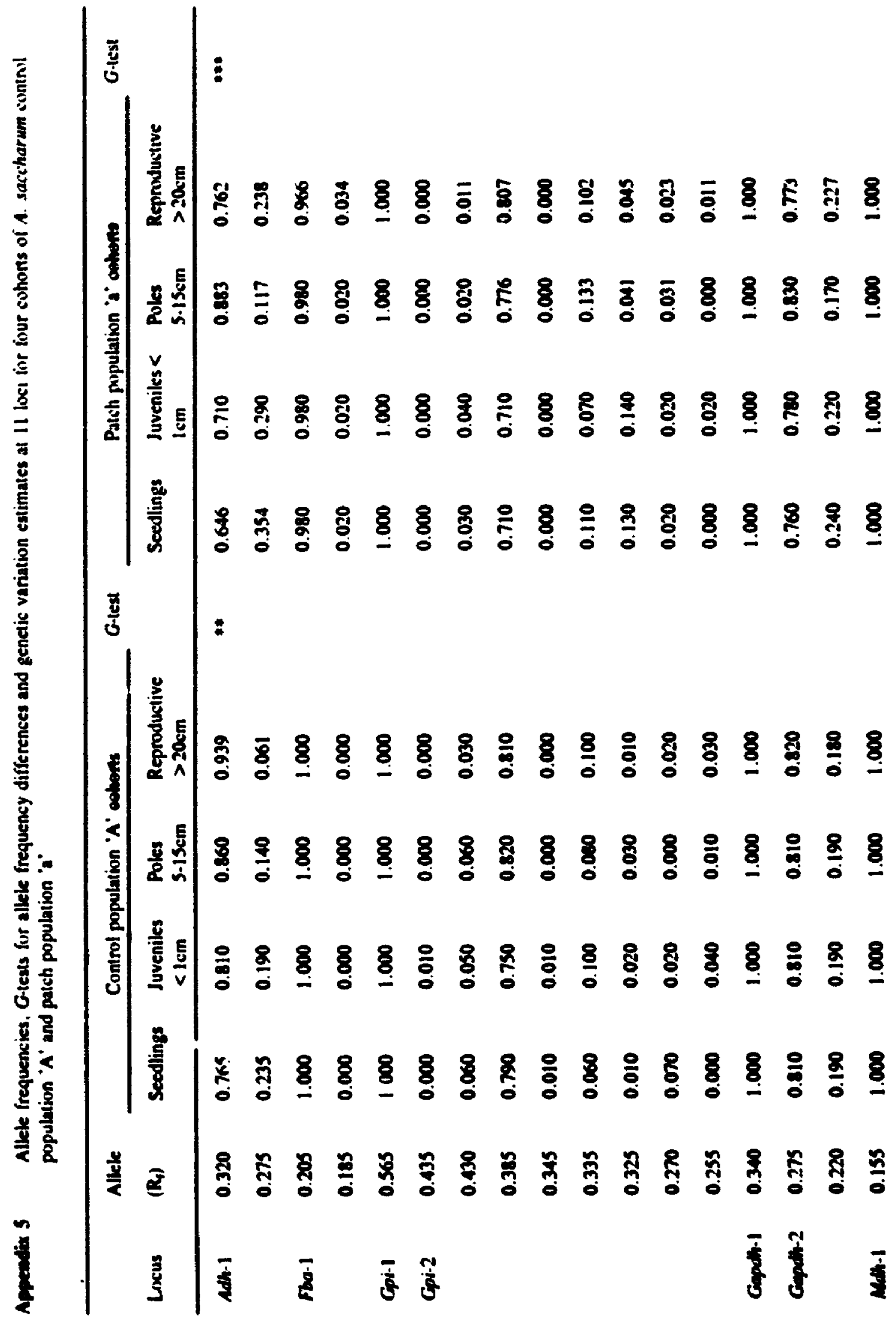




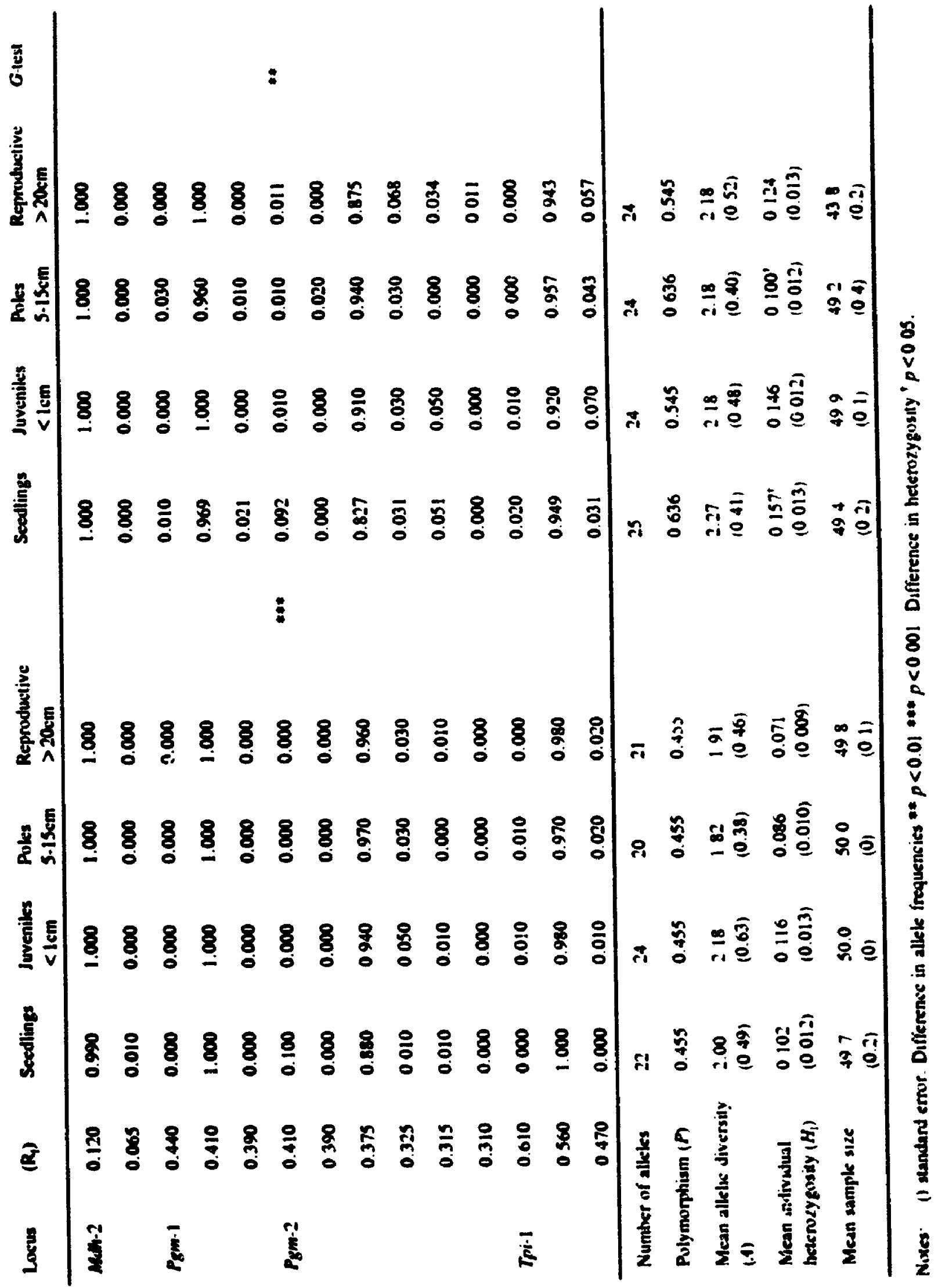




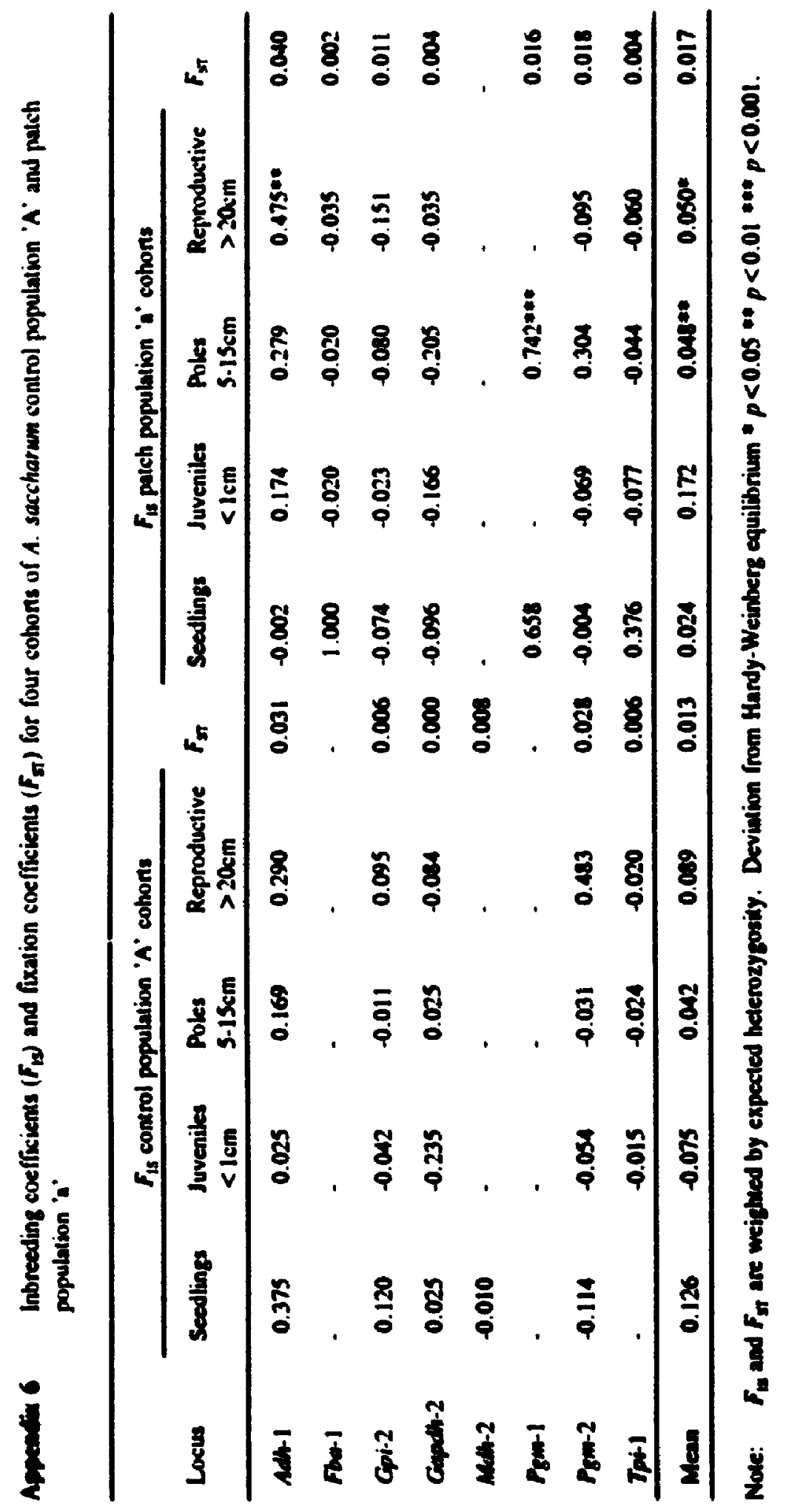




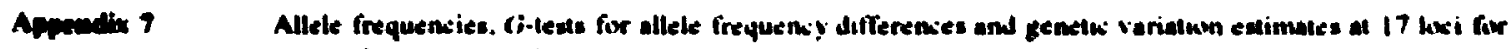
A. saccharem rezional popoulations.

\begin{tabular}{|c|c|c|c|c|c|c|c|c|c|c|c|}
\hline \multirow[b]{2}{*}{ Losus } & \multirow{2}{*}{$\begin{array}{l}\text { Allele } \\
\text { (R) }\end{array}$} & \multicolumn{9}{|c|}{ Regiumal pupulations: } & \multirow[b]{2}{*}{ ionen } \\
\hline & & CB & $\boldsymbol{F R}$ & FN & $\mathbf{A}$ & BY & $\mathbf{w}$ & $\mathbf{M M}$ & $\mathbf{P P}$ & FK & \\
\hline \multirow[t]{4}{*}{ Adh-1 } & 0.355 & 0.000 & 0.010 & 0.000 & 0000 & 0.000 & U.000 & $0.0 \mathrm{~m})$ & $0.0(x)$ & 000 & $\bullet$ \\
\hline & 0.320 & 0.898 & 0.750 & 0.810 & 0.764 & 0.730 & 0.729 & 0.819 & 0.765 & 0.760 & \\
\hline & 0.275 & 0.092 & 0240 & 0.190 & 0.235 & 0.270 & 0.271 & 0.141 & 0.235 & 0.230 & \\
\hline & 0.250 & 0.010 & 0.000 & 0.000 & 0.000 & 0.000 & 0.000 & 0.000 & 01000 & 0.010 & \\
\hline \multirow[t]{5}{*}{$\operatorname{Aat}-2$} & 0.400 & 0.000 & 0.053 & 0.000 & 0.020 & 0.000 & 0.000 & 0.032 & 01000 & 0.000 & $\cdots$ \\
\hline & 0.350 & 0.051 & 0.000 & 0.050 & 0.000 & 0.010 & 0.000 & 0.021 & $0(100)$ & 0000 & \\
\hline & 0.285 & 0.755 & 0.656 & 0.700 & 0.743 & 0.776 & 0.708 & 0.252 & 0.451 & $0,6,30$ & \\
\hline & 0.170 & 0.020 & 0.000 & 0.000 & 0.000 & 0.020 & 0.125 & 0.0000 & 0.1130 & 0.022 & \\
\hline & 0.150 & 0.173 & 0.281 & 0.250 & 0.235 & 0.194 & 0.167 & (0.04s & 0.024 & 0.344 & \\
\hline \multirow[t]{2}{*}{ Fta-1 } & 0.205 & 1.000 & 1.000 & 1.000 & 1.000 & 1.000 & 1.000 & 1.000 & $0.9 \times 1)$ & $0.9 \% 0$ & \\
\hline & 0.185 & 0.000 & 0.000 & 0.000 & 0.000 & 0.000 & 0.000 & $0.0 \mathrm{no}$ & 0.010 & 0.010 & \\
\hline Gpi-1 & 0.565 & 1.000 & 1.000 & 1.000 & 1.000 & 1.000 & 1.000 & 1.000 & 1.000 & 1.000 & \\
\hline \multirow[t]{9}{*}{ Gpi-2 } & 0.450 & 0.050 & 0.020 & 0.000 & 0.000 & 0.000 & 0.040 & $(0.000)$ & $0.0 \times 3)$ & 0.000 & $\bullet$ \\
\hline & 0.430 & 0.000 & 0.000 & 0.020 & 0.060 & 0.011 & 0.000 & 0.010 & 1000 & 0.041 & \\
\hline & 0.425 & 0.000 & 0.000 & 0.000 & 0.000 & 0.000 & 0.000 & 0.020 & $0 .(0 x)$ & 0.000 & \\
\hline & 0.389 & 0.830 & 0.840 & 0.920 & 0.790 & 0.819 & 0.840 & $0 . \mathrm{mo}$ & 0.971 & 0.750 & \\
\hline & 0.345 & 0.090 & 0.020 & 0.040 & 0.010 & 0.096 & 0.000 & 0.060 & 0.000 & 0.000 & \\
\hline & 0.335 & 0.000 & 0.070 & 0.000 & 0.060 & 0.074 & 0.020 & 0.160 & 0.010 & 0.040 & \\
\hline & 0.325 & 0.000 & 0.000 & 0.000 & 0.010 & 0.000 & 0.000 & 0.000 & 0.020 & 0.150 & \\
\hline & 0.295 & 0.000 & 0.000 & 0.000 & 0.000 & 0.000 & 0.000 & 0.000 & 0.000 & 0.010 & \\
\hline & 0.270 & 0.030 & 0.050 & 0.020 & 0.070 & 0.000 & 0.080 & n.050 & 0.000 & 0.000 & \\
\hline Gepath-1 & 0.340 & 1.000 & 1.000 & 1.000 & 1.000 & 1.000 & 1.000 & 1.000 & 1.000 & 1.000 & \\
\hline \multirow[t]{2}{*}{ Gaph-2 } & 0.275 & 0.940 & 0.950 & 0.950 & 0.810 & 0.850 & 0.848 & 0.847 & 0971 & 0920 & $\bullet$ \\
\hline & 0.220 & 0.060 & 0.050 & 0.050 & 0.190 & 0.120 & 0.102 & 0153 & 0029 & 0000 & \\
\hline$M d n-1$ & $0.15 s$ & 1.000 & 1.000 & 1.000 & 1.000 & 1.000 & 1.000 & 1.000 & 1.000 & 1.000 & \\
\hline \multirow[t]{2}{*}{ Mdh-2 } & 0.120 & 1.000 & 1.000 & 1.000 & 0.990 & 1.000 & 10000 & 1.0000 & 1.0000 & 1.000 & \\
\hline & 0.065 & 0.000 & 0.000 & 0.000 & 0.010 & 0.000 & 0.000 & 0.000 & 0.000 & 0.000 & \\
\hline MAM-I & 0.420 & 1.000 & 1.000 & 1.000 & 1.000 & 1.000 & 1000 & 1.000 & 1.0000 & 1.0000 & \\
\hline \multirow[t]{4}{*}{ Menp-2 } & 0.300 & 0.354 & 0.282 & 0.289 & 0.204 & 0.292 & 0.057 & 0128 & 0314 & 0.220 & $\bullet \bullet$ \\
\hline & 0.270 & 0.488 & 0.333 & 0.422 & 0.735 & 0.347 & 0.543 & 0.5000 & 0.627 & 1060 & \\
\hline & 0.230 & 0.134 & 0.244 & 0.233 & 0.061 & 0.319 & 0.300 & 0221 & 0.054 & 01020 & \\
\hline & 0.200 & 0.024 & 0.141 & 0.056 & 0.000 & 0.042 & 0.100 & 0.151 & 0.000 & 0.000 & \\
\hline
\end{tabular}




\begin{tabular}{|c|c|c|c|c|c|c|c|c|c|c|c|}
\hline Lerus & $\left(R_{1}\right)$ & $\mathrm{CB}$ & FR & FN & A & BY & $\mathbf{K J}$ & $M M$ & $P P$ & Pr & O-teat \\
\hline \multirow[t]{2}{*}{ Praw-I } & 0440 & 0000 & 0020 & 0000 & 0.000 & 0.000 & 0000 & 0.020 & 0.000 & 0.031 & • \\
\hline & 0.410 & 1.000 & $0.98 \mathrm{BO}$ & 1.000 & 1.000 & 1.000 & 1.000 & 0940 & 1.000 & 0.969 & \\
\hline \multirow[t]{5}{*}{$P_{\mathrm{xm}-2}$} & () 410 & 0.000 & 0.000 & 0.000 & 0100 & 0.000 & 0.000 & 0.010 & 0.020 & 0.040 & $\bullet$ \\
\hline & 0.390 & 0.000 & 0.000 & 0.000 & 0.000 & 0.000 & 0.000 & 0.010 & 0.000 & 0.020 & \\
\hline & 0.375 & 0990 & 0.970 & 0.920 & 0.810 & 0.924 & 0.920 & 0.960 & 0.873 & 0.120 & \\
\hline & 0.325 & 0010 & 0.020 & 0.020 & 0.010 & 0.054 & 0.020 & 0.020 & 0.010 & 0.000 & \\
\hline & 0.315 & 0.000 & 0.010 & 0.000 & 0.010 & 0.022 & 0.000 & 0.000 & 0.098 & 0.120 & \\
\hline \multirow[t]{3}{*}{$P_{R m-3}$} & 0.235 & 0.000 & 0.000 & 0.010 & 0.000 & 0.010 & 0.000 & 0.010 & 0.157 & 0.000 & $\infty$ \\
\hline & 0.205 & 1.000 & 1.000 & 0.990 & 0.960 & 0.990 & 1.000 & 0.990 & 0.843 & 1.000 & \\
\hline & 0.170 & 0.000 & 0.000 & 0.000 & 0.020 & 0.000 & 0.000 & 0.000 & 0.000 & 0.000 & \\
\hline \multirow[t]{3}{*}{$P_{x m-4}$} & 0.170 & 1.000 & 1.000 & 0.927 & 0.990 & 0.988 & 1.000 & 0.967 & 1.000 & 0.940 & $\infty$ \\
\hline & 0.195 & 0.000 & 0.000 & 0.000 & 0.000 & 0.000 & 0.000 & 0.000 & 0.000 & 0.040 & \\
\hline & $0.1 \$ 0$ & 0.000 & 0.000 & 0.073 & 0.010 & 0.012 & 0.000 & 0.033 & 0.000 & 0.000 & \\
\hline \multirow[t]{3}{*}{$T_{p i-1}$} & 0.560 & 0.980 & 0.940 & 0.920 & 1.000 & 0.950 & 0.890 & 0.990 & 0.804 & $0.9 \times 0$ & $\bullet \bullet$ \\
\hline & 0.470 & 0.010 & 0.060 & 0.020 & 0.000 & 0.050 & 0.110 & 0.010 & 0.196 & 0.040 & \\
\hline & 0.375 & 0.010 & 0.000 & 0.000 & 0.000 & 0.000 & 0.000 & 0.000 & 0.000 & 0.000 & \\
\hline \multirow[t]{2}{*}{$T p-2$} & $0,+30$ & 1.000 & 1.000 & 1.000 & 1.000 & 1.000 & 0.980 & 1.000 & 1.000 & 1.000 & \\
\hline & 0.295 & 0.000 & 0.000 & 0.000 & 0.000 & 0.000 & 0.020 & 0.000 & 0.000 & 0.000 & \\
\hline \multicolumn{2}{|c|}{ Number of alleles } & 32 & $\mathbf{3 3}$ & 31 & 34 & 33 & 30 & 37 & 31 & 35 & \\
\hline \multicolumn{2}{|c|}{ Polymuophism (P) } & 0.412 & 0.471 & 0.529 & 0.529 & 0.529 & 0.471 & 0.588 & 0.529 & 0.588 & \\
\hline \multicolumn{2}{|c|}{$\begin{array}{l}\text { Meen alkelic } \\
\text { divernily }(A)\end{array}$} & $\begin{array}{l}1.88 \\
(0.30)\end{array}$ & $\begin{array}{l}1.94 \\
(0.30)\end{array}$ & $\begin{array}{l}1.82 \\
(0.25)\end{array}$ & $\begin{array}{l}2.00 \\
(0.33)\end{array}$ & $\begin{array}{l}1.94 \\
(0.28)\end{array}$ & $\begin{array}{l}1.76 \\
(0.25)\end{array}$ & $\begin{array}{l}2.18 \\
(0.36)\end{array}$ & $\begin{array}{l}1.82 \\
(0.23)\end{array}$ & $\begin{array}{l}2.05 \\
(0.29)\end{array}$ & \\
\hline \multicolumn{2}{|c|}{$\begin{array}{l}\text { Mean individual } \\
\text { heteruzysoming ( } H)\end{array}$} & $\begin{array}{l}0.028 \\
(0.008)\end{array}$ & $\begin{array}{l}0.129 \\
(0.009)\end{array}$ & $\begin{array}{l}0.120 \\
(0.008)\end{array}$ & $\begin{array}{l}0.120 \\
(0.012)\end{array}$ & $\begin{array}{l}0.111 \\
(0.010)\end{array}$ & $\begin{array}{l}0.108 \\
(0.009)\end{array}$ & $\begin{array}{l}0.131 \\
(0.009)\end{array}$ & $\begin{array}{l}0.094 \\
(0.010)\end{array}$ & $\begin{array}{l}0.131 \\
(0.010)\end{array}$ & \\
\hline \multicolumn{2}{|c|}{ Meen mample size } & $\begin{array}{l}4.8 \\
(0.5)\end{array}$ & $\begin{array}{l}48.6 \\
(0.7)\end{array}$ & $\begin{array}{l}49.3 \\
(0.3)\end{array}$ & $\begin{array}{l}49.6 \\
(0.2)\end{array}$ & $\begin{array}{l}4.5 \\
(0.9)\end{array}$ & $\begin{array}{l}47.8 \\
(1.1)\end{array}$ & $\begin{array}{l}4.6 \\
(0.5)\end{array}$ & $\begin{array}{l}49.2 \\
(0.6)\end{array}$ & $\begin{array}{l}4.7 \\
(0.2)\end{array}$ & \\
\hline
\end{tabular}

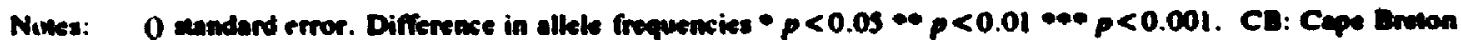
FR: Forillon FN: Fuody A: Getinenu BY: Georgian Bay IO: Kejimkujik MM: La Mouricie PP: Poim Palee PR: Puknalswe. 


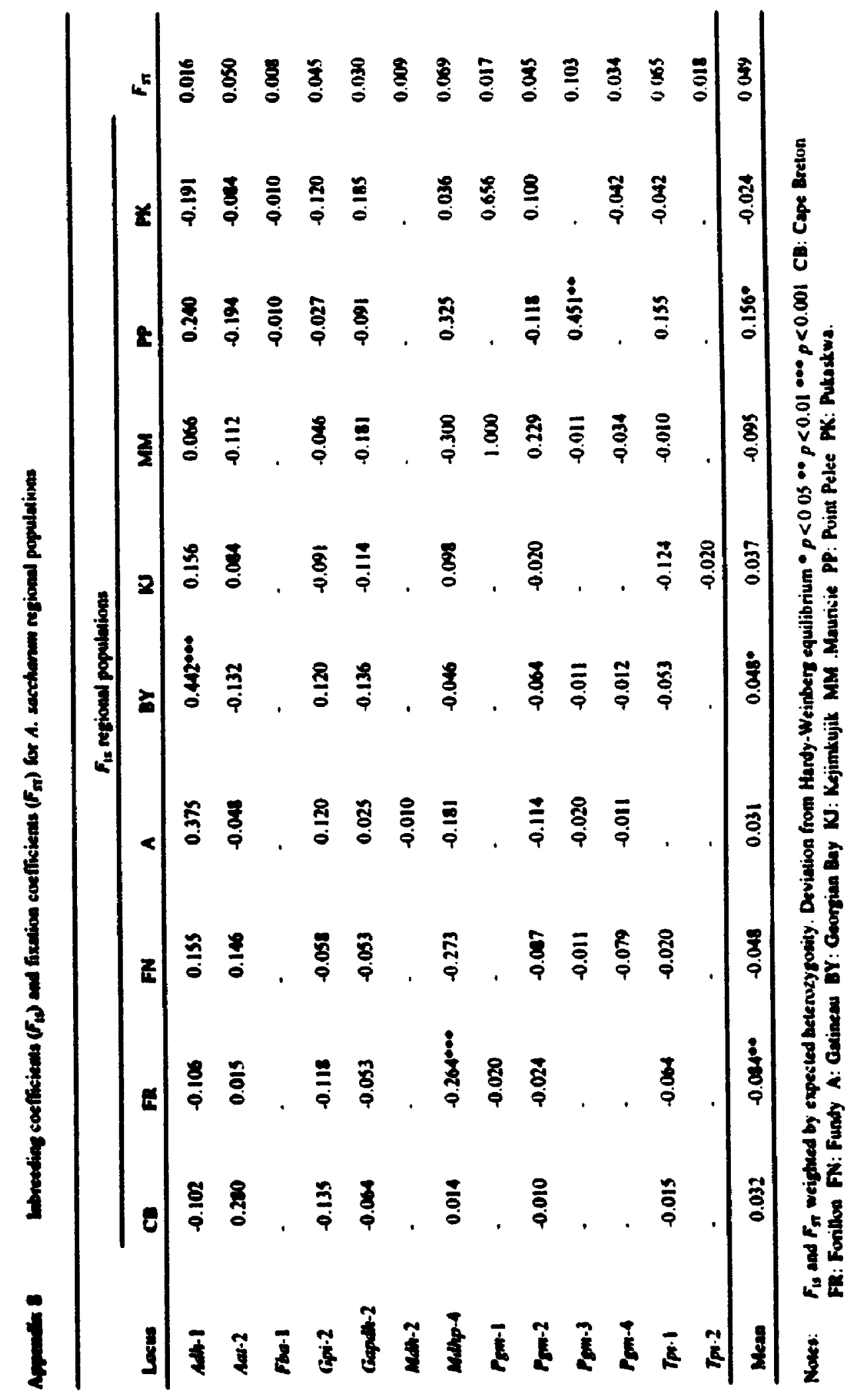




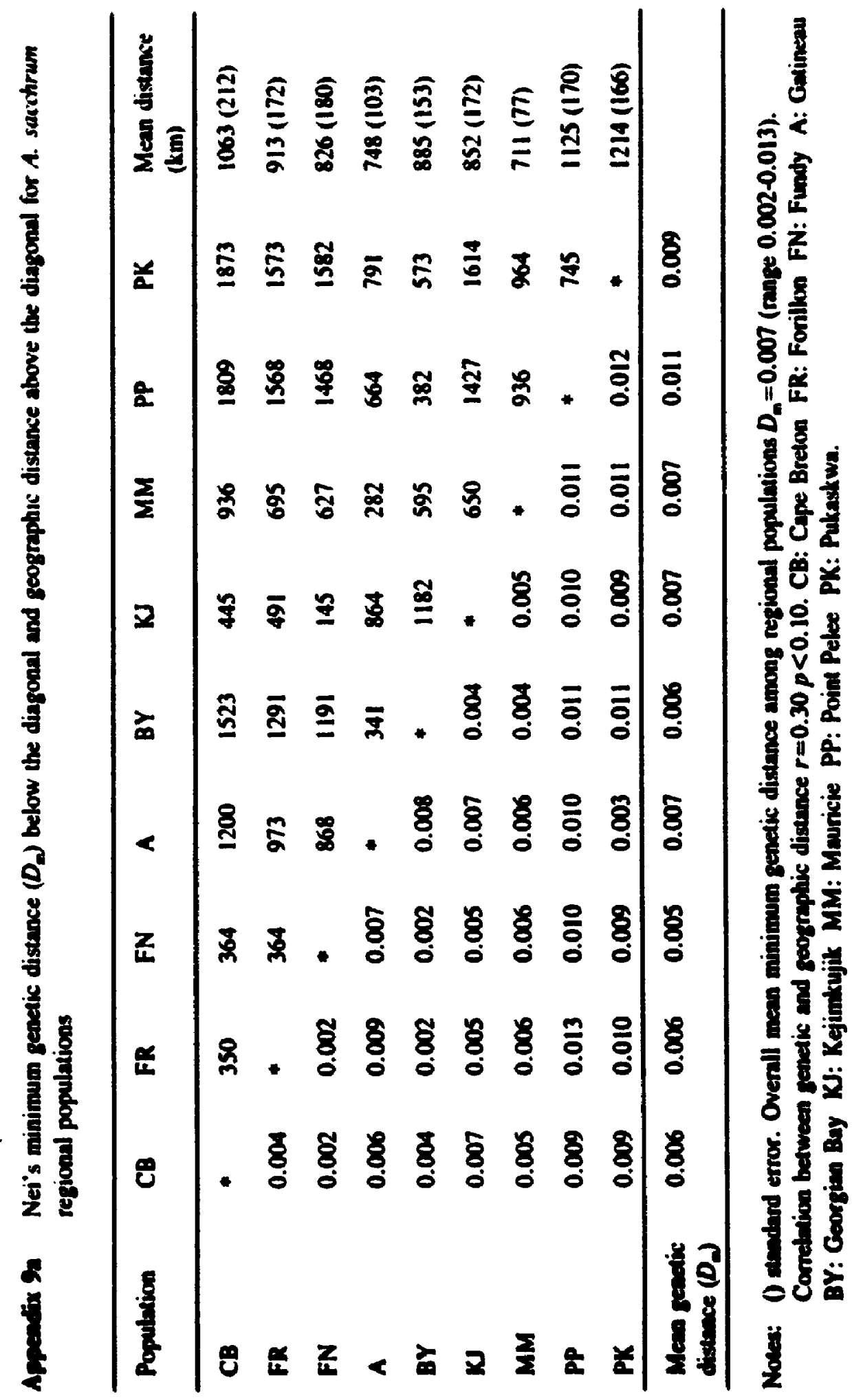




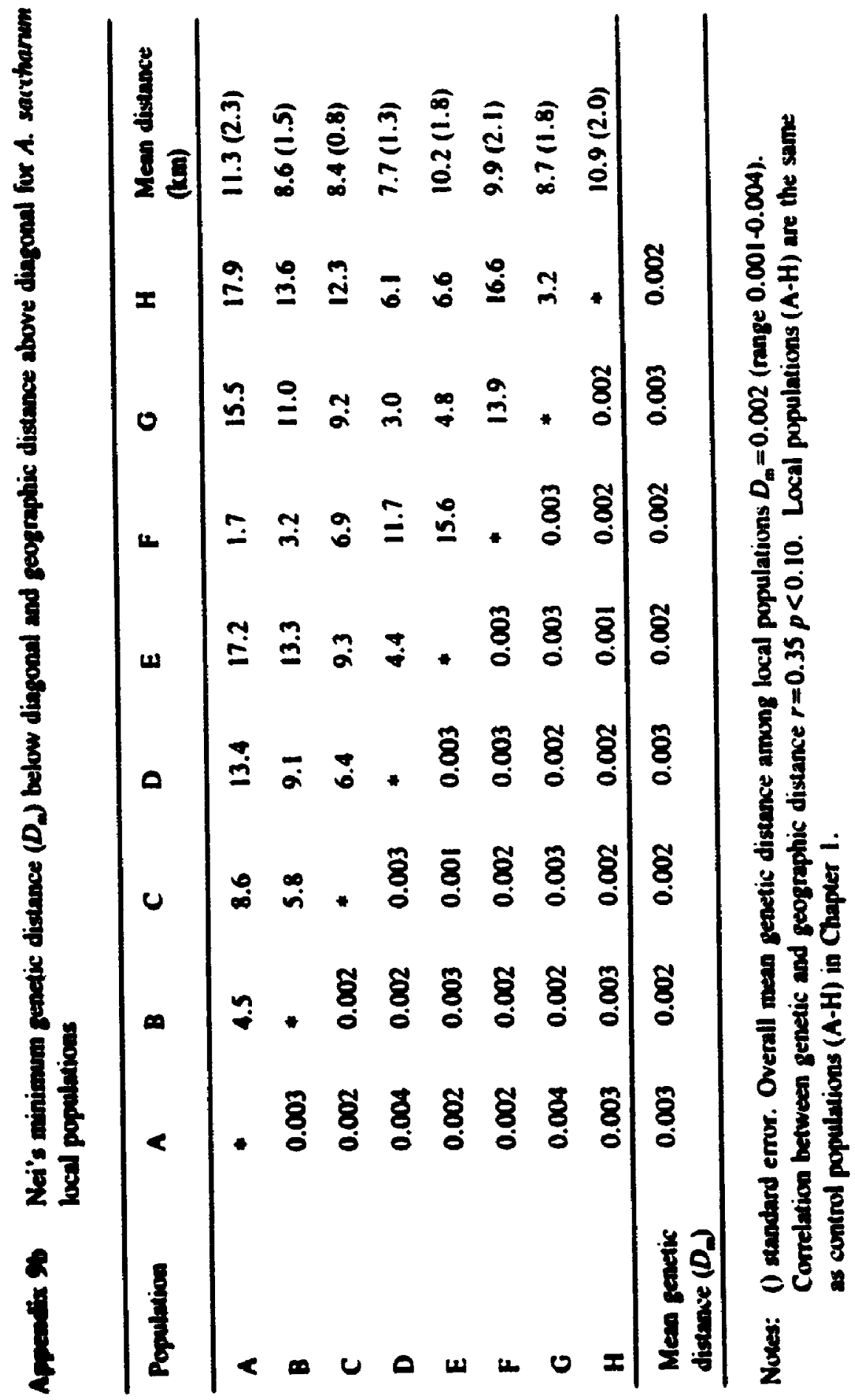




\section{REFERENCES}

Barbujani, G. 1987. Autocorrelation of gene frequencies under isolation by distance. Genetics, 117, 777-782.

Bassett, I.J. 1969. Airborne pollen dispersal of some trees and shrubs in the Ottawa district. Trail and Landscape, 3, 42-44.

Benzie, J.W. 1959. Sugur maple and yellow birch seed dispersal from a fully srocked sfand of mature northern hardwonds in the upper peninsula of Michigan. Lake States Forest Experiment Station Technical Note 561.

Billington, H.L. 1991. Effect of population size on genetic variation in a dioecious conifer. Conservarion Binlogy, 5, 115-119.

Bousquet, J., Cheliak, W.M. and Lalonde, M. 1987. Genetic differentiation among 22 populations of green alder (Almus crispa) in central Québec. Canadian Journal of Foresi Research, 17, 219-227.

Bousquet, J., Cheliak, W.M. and Lalonde, M. 1988. Allozyme variation within and among mature populations of speckled alder (Alnus rugosa) and relationships with green alder (A. crispa). American Journal of Borany, 75, 1678-1686.

Boyle, T., Liengsiri, C. and Piewluang, C. 1990. Genetic structure of black spruce on two contrasting sites. Herediry, 65, 393-399.

Braun, E.L. 1964. Deciduous Forests of Eastern North America. Hafner, New York.

Bryant, E.H., McCommas, S.A. and Combs, L.M. 1996. The effect of an experimental bottleneck upon quantitative genetic variation in the housefly. Generics, 114, 1191-1211.

Burgess, R.L. 1988. Community organization: effects of landscape fragmentation. Canadian Journal of Botany. 66, 2687-2690.

Buri, P. 1956. Gene frequency in small populations of mutant Drosophila. Evolution, $10,367-402$.

Cheliak, W.M. and Pitel, J.A. 1984. Techniques for starch gel electrophor sis of enzymes from forest iree species. Canadian Forestry Service Information Report $\mathrm{PI}-\mathrm{X}-\mathbf{4 2}$. 
Clark, P.J. and Evans, F.C. 1954. Distance to nearest neighbour as a measure of spatial relationships in populations. Ecology. 35. $+45-45.3$.

Cliff, A.D. and Ord, J.K. 1981. Spatial Processe's: Misklels and Applicurioms, Pion. London.

Comps, B., Thiebaut, B., Paule, L., Merzeau, D. and Letouzey, J. 1990. Allozymic variability in beechwoods (Fagus sy/lutica L.) over central Europe: spatial differentiation among and within populations. Herediry. 65. 407-417.

Dietz. J. 1983. Permutation tests for association between two distance matrices. Sysrematic Zoology, 32, 21-26.

Dirschl, H.B. 1988. The usc of the SEDFAL simulation model to extimate the past seed dispersial of Acer negunde. Acer saccharum, and Fraximus americana irees in farmland south of Orrawa. BSc Hons Thesis. Carleton University.

Donnelly, K. 1978. Simulation to determine the variance and edge-effect of total nearest neighbour distance. In: Hodder, I.R. (ed.) Simulation Merhords in Archaeology, Cambridge University Press, London, pp. 91-95.

Dunning, J.B., Danielson, B.J. and Pulliam, H.R. 1992. Ecological processes that affect populations in complex landscapes. Oikos, 65, 169-175.

Dyke, A.S. and Prest, V.K. 1987a. Late Wisconsinan and Holocene Retreaf of the Laurentide Ice Sheet, Map 1702A. Geological Survey of Canada, Ottawa.

Dyke, A.S. and Prest, V.K. 1987b. Paleogengraphy of Northem North America 18 000-5 000 Years Ago, Map 1703A. Geological Survey of Canada, Ottawa.

Epperson, B.K. 1990. Spatial autocorrelation of genotypes under directional selection. Generics, 124, 757-771.

Epperson, B.K. and Allard, R.W. 1989. Spatial autocorrelation analysis of the distribution of genotypes within populations of lodgepole pine. Genetics, 121, 369377.

Farris, M.A. and Mitton, J.B. 1984. Population density, outcrossing rate, and heterozyzote superiority in ponderosa pine. Ewolution, 38, 1151-1154.

Forcier, L.K. 1973. Seedling patrem and population dynamics, and the reproductive strategies of sugar maple, beech and yellow birch at Hubbard Bronk. Phd Thesis, Yale University. 
Fore, S.A., Hickey, R.J., Guttman, S.I. and Vankat, J.L. 1992a. Temporal differences in genetic diversity and structure of sugar maple in an old-growth forest. Camadian Journal of Forest Research, 22, 1504-1509.

Fore, S.A., Hickey, R.J., Vankat, J.L., Guttman, S.I. and Schaefer, R.L. 1992b. Genetic structure after forest fragmentation: a landscape ecology perspective on Acer succharum. Canadian Jourmal of Borany, 70, 1659-1668.

Frankel, O.H. and Souk, M.E. 1981. (eds) Conservation and Evolurion, Cambridge University Press, Cambridge.

Gabriel, W.J. 1967. Reproductive behaviour in sugar maple: self-compatibility, cross-compatibility, agamospermy, and agamocarpy. Silvae Generica, 16, 165-168.

Gabriel, W.J. 1968. Dichogamy in Acer saccharum. Boranical Gazette, 129, 334-338.

Gabriel, W.J. and Garrett, P.W. 1984. Pollen vectors in sugar maple (Acer saccharum). Camadian Journal of Botany, 62, 2889-2890.

Gilpin, M. 1991. The genetic effective size of a metapopulation. Biological Journal of the Linnean Siciery, 42, 165-175.

Green, D.S. 1980. The terminal velocity and dispersal of spinning samaras. American Journal of Botul y, 67, 1218-1224.

Guries, R.P. and Ledig, F.T. 1982. Genetic diversity and population structure in pitch pine (Pinus rigida Mill.). Ewhlurion, 36, 387-402.

Guries, R.P. and Nordheim, E.V. 1981. Flight characteristics and dispersal potential of maple samaras. Forest Science, 30, 434-440.

Hamrick, J.L. 1983. The distribution of genetic variation within and among natural plant populations. In: Schonewald-Cox, C.M., Chambers, S.M., MacBryde, B. and Thomas, W.L. (eds) Generics and Consenation, Benjamin/Cummings, London, pp. 335-344.

Hamrick, J.L. and Loveless, M.D. 1998. The genetic structure of tropical tree populations, associations with reproductive biology. In: Bock, J.H. and Linhart, Y.B. (eds) The Evolurionary Ecolngy of Plants, Westview Press, Boulder, pp. 129-146. 


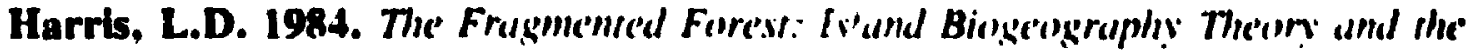
Presenation of Bionic Diversing. The Unwersity of Chicago Press. Chicago.

Hett, J.M. and Loucks, O.L. 1971. Sugar maple (.tecer xacihurum Marsh.) suedling mortality. Journal of Ecology. 59. 507-520.

Hyun, J.O., Rajora, O.P. and Zsurfa, L. 1987. Genetic variation in treinbling aspen in Ontario based on isozyme studies. Camadian Jourmal of Forest Resiear'h. 17, 1134-1138.

Johnson, W.C. 1988. Estimating dispersibility of Acer. Frarimus and Tilis in fragmented landscapes from patterns of seedling establishment. Lundicupe Ecology, 1, 175-187.

Kapos, V. 1989. Effects of isolation on the water status of forest palches in the Brazilian Amazon. Journal of Tropical Ecology. 5, 173-185.

Kephart, S.R. 1990. Starch gel electrophoresis of plant isozymes: a comparative analysis of techniques. American Journal of Borany, 77, 693-712.

Knowles, P., Perry, D.J. and Foster, H.A. 1992. Spatial genetic structure in iwo tamarack (Larix laricina (Du Roi) K. Koch) populations with differing establishment histories. Eiv/ution, 46, 572-576.

Kriebel, H.B. 1957. Patterns of genetic variation in sugar maple. Re'search Hullerin Ohio Agricultural Experimental Station, 791. 1-55.

Land. R. and Barrowclough, G.F. 1987. Effective population size, genetic variation, and their use in population management. In: Soulé, M.E. (ed), Viable Popularions for Conservarion, Cambridge Press, Cambridge, pp. 87-123.

Ledig, F.T. and Korbobo, D.R. 1983. Adaptation of sugar maple populations along altitudinal gradients: photosynthesis, respiration, and specific leaf weight. American Journal of Bolany, 70, 256-265.

Lelliot, M. 1987. Inherirance of eight enzyme systems in sugar muple (Acer saccharum Marsh.). BSc Hons Thesis, Lakehead University.

Li, P. and Adams, W.T. 1989. Range-wide patterns of allozyme variation in Douglas-fir (Pseudorsuga menziesii). Camadian Journal of Forest Research, 19. 149-161. 
Linhart, Y.B., Mitton, J.B., Sturgeon, K.B. and Davis, M.L. 198: . Genetic variation in space and time in a population of ponderosa pine. Herediry, 46. 407-426.

Logan, K.T. 1965. Growth of tree seedlings as affected by light intensity: I. White Birch. Yellow Birch. Sugar Maple and Silver Maple. Canadian Department of Forestry Publication No. 1121.

Lord, J.M. and Norton, D.A. 1990. Scale and the spatial concept of fragmentation. Conservution Biology, 4, 197-202.

Loveless, M.D. and Hamrick, J.L. 1984. Ecological determinants of genetic structure in plant populations. Annual Review of Ecology and Systematics, 15, $65-95$.

Margules, C.R. and Nicholls, A.O. 1987. Assessing the conservation value of remnant habitat 'islands': mallee patches on the western Eyre Peninsula, South Australia. In: Saunders, D.A., Amold, G.W., Burbidge, A.A. and Hopkins, A.J.M. (eds) Nurure Conservation: the Role of Remnants of Native Vegetation, Surrey Beaty and Sons, Chipping Norton, pp. 89-102.

Marquis, D.A. 1975. Seed storage and germination under northern hardwood forests. Canadian Journal of Forest Research, 5, 478-484.

McClenaghan, L.R. and Beauchamp, A.C. 1986. Low genetic differentiation among isolated populations of the California fan palm (Washingronia filifera). Eivolution, 40, 315-322.

McCommas, S. A. and Bryant, E. H. 1990. Loss of electrophoretic variation in serially bottlenecked populations. Herediny, 64, 315-321.

Middleton, J.D. 1982. On cernain spatial characteristics of the distriburion of whrulland species in farmland. PhD Thesis, Carleton University.

Mitton, J.B. and Grant, M.C. 1980. Observations on the ecology and evolution of quaking aspen, Populus tremuloides, in the Colorado front range. American Journal of Botany, 67, 202-209.

Moran, G.F., Bell, J.C. and Eldridze, K.J. 1938. The genetic structure and the conservation of the five natural populations of Pinus radiasa. Canadian Journal of Forest Research, 18, 506-514. 
Moran, G.F. and Hopper. S.D. 1983. Genetic diversity and the insular population structure of the rare granite rock species. Eluculyperss cas'sia Benth. Atustralian Journal of Botany, 31. 161-172.

Mulcahy, D.L. 1975. Differential mortality among cohorts in a population of Acer succharum (Aceraceae) seedlings. Amcrican Journul of Busan!. 62, +22-426.

sona, O. 1990. Population genetics in forest tree improvement. In: Brown. A.H.D., Clegg, M.T., Kahler, A.L. and Weir, B.S. (eds) Plam Population Generics, Breeding. and Feneric Resources. Sinauer Associates, Sunderland, pp. 282-298.

Murawski, D.A. and Hamrick, J.L. 1991. The effect of the density of nowering individuals on the mating systems of nine tropical tree species. Heredity, 67. 167-174.

Nei, M. 1973. Analysis of gene diversity in subdivided populations. Proceredings of the National Academy of Science's U.S.A., 70, 3321-3323.

Nei, M. 1977. F-statistics and analysis of gene diversity in subdivided populations. Annals of Human Generics, 41, 225-233.

Nei, M. 1987. Molecular Evolurionary Generics. Columbia University Press. New York.

Nei, M., Maruyama, T. and Chakraborty, R. 1975. The bottlencek effect and genetic variability in populations. Evolurion, 29, 1-10.

Nigh, T.A., Pallardy, S.G. and Garrett, H.E. 1985. Sugar maple-environment relationships in the River Hills and Central Ozark Mountains of Misssouri. The American Midland Naturalist, 114, 235-251.

Nybom, H. 1990. Genetic variation in ornamental apple trees and their seerlings (Malus, Rosaceae) revealed by DNA 'fingerprinting' with the M13 repeat probe. Hereditas, 113, 17-28.

Occhietti, S. 1989. Quaternary geology of St Lawrence Valley and adjacent Appalachian subregion. In: Fulton, R.J. (ed) Quarermary Cenlogy of Canada and Greenland. Geologyical Survey of Canada, Ottawa, pp. 350-388.

Perry, D.J. and Knowles, P. 1989. Allozyme variation in sugar maple at the northern limit of its range in Ontario, Canada. Canadian Journal of Forest Research, 19, 509-514. 
Perry, D.J. and Knowles, P. 1991. Spatial genetic structure within three sugar maple (Acer saccharum Marsh.) stands. Herediny, 66, 137-142.

Plessas, M.E. and Strauss, S.H. 1986. Allozyme differentiation among populations, stands, and cohorts in Monterey pine. Canadian Journal of Forest Research, 16. 1155-1164.

Polans, N.O. and Allard, R.W. 1989. An experimental evaluation of the recovery potential of ryegrass populations from genetic stress resulting from restriction of population size. Evolurion. 43, 1320-1324.

Ranney, J.W., Brunner, M.C. and Levenson, J.B. 1981. The importance of edge in the structure and dynamics of forest islands. In: Burgess, R.L. and Sharpe, D.M. (eds) Forrest Island Dynamics in Man-dominated Landscapes, Springer Verlag. New York, pp. 67-96.

Roberds, J.H. and Conkle, M.T. 1984. Genetic structure in loblolly pine stands: allozyme variation in parents and progeny. Forest Science, 30, 319-329.

Ror, D.A. and Bentzen, P. 1989. The statistical analysis of mitochondrial DNA polymorphisms: Chi-square and the problem of small samples. Molecular Biology and Evolution, 6, 539-545.

Rowe, J.S. 1977. Foress Regions of Canada. Canadian Forestry Service Publication No. 1300.

Sampson, J.F., Hopper, S.D. and James, S.H. 1988. Genetic diversity and the conservation of Eucalyprus crucis Maiden. Ausiralian Journal of Borany, 36, 447-460.

SAS Institute Inc. 1988. SAS/STAT User's Guide, Release 6.03 Edition, SAS Institute Inc, Cary.

Saunders, D.A., Hobbs, R.J. and Margules, C.R. 1991. Biological consequences of ecosystem fragmentation: a review. Conseruarion Biology, 5, 18-32.

Schaal, B.A. and Levin, D.A. 1976. The demographic genetics of Liatris cylindracea Michx (Compositae). The American Naturalist, 110, 191-206.

Schnabel, A. and Hamrick, J.L. 1990. Organization of genetic diversity within and amung populations of Gledirsia iriacanthos (Leguminosae). American Joumal of Borany. 77. 1060-1069. 
Scogsan, H.J. 1978. The Flora of Canuda: Parr 3. National Museum of Canada. Ottawa.

Sharpe, D.M. and Fields. D.E. 1982. Integrating the effects of climate and seed fall velocities on seed dispersal by wind: a model and application. Ecologicul Modelling, 17, 297-310.

Shea, K.L. 1990. Genetic variation between and within populations of Engelinann spruce and subalpine fir. Genome, 33, 1-8.

Slatkin, M. 1985. Rare alleles as indicators of gene flow. Evolurion, 39. 53-65.

Slakin, M. and Barton, N.H. 1989. A comparison of three indirect methods for estimating average levels of gene flow. Evolution. 43, 1,349-1,368.

Smouse, P.E., Long, J.C. and Sokal, R.R. 1996. Multiple regression and correlation extensions of the mantel test of matrix correspondence. Systematic Zoology, 35, 627-632.

Smouse, P.E. and Neel, J.V. 1977. Multivariate analysis of gametic disequilibrium in the Yanomama. Generics, 85, 733-752.

Sokal, R.R. and Jacquez, G.M. 1991. Testing inferences about microevolutionary processes by means of spatial autocorrelation analysis. Evolution, 45. 152-168.

Sokal, R.R. and Rohlf, F.J. 1981. Biomerry, Freeman and Company, New York.

Sokal, R.R. and Wartenberg, D.E. 1983. A test of spatial autocorrelation analysis using an isolation-by-distance model. Generics, 105, 219-237.

Soule, M.E. 1996. (ed) Conserwation Biology: The Science of Scarciry and Diversiny, Sinauer Associates, Sunderland.

Soule, M.E. 1987. (ed) Viable Populations For Conserwation, Cambridge University Press, Cambridge.

Swofford, D.L. and Selander, R.B. 1939. BlOSYS-1.7: A Computer Program for the Amalysis of Allelic Variarion in Population Generics and Biochemical Systemarics, Illinois Natural History Survey, Illinois.

Templeton, A.R., Shaw, K., Routman, E. and Davis, S.K. 19s0. The genetic consequences of habitat fragmentation. Ammals of the Missouri Bovanical Gurden, 77, 13-27. 
Tremblay, M. and Simon, J. 1989. Genetic structure of marginal populations of white spruce (Piced slanca) at its northern limit of distribution in NouveauQuébec. Canadian Journal of Forest Research, 19, 1371-1379.

Wales, B.A. 1967. Climate, microclimate and vegetation relationships on north and south forest boundaries in New Jersey. The William L. Hutcheson Memorial Forest Bullerin, 2, 1-60.

Wartenberg, D.E. 1989. SAAP - A Sparial Autocorrelation Analysis Program. University of Medicine and Dentistry of New Jersey, New Jersey.

Weeden, N.F. and Wendel, J.F. 1989. Genetics of plant isozymes. In: Soltis, D.E. and Soltis, P.S. (eds) lsozymes in Plamt Biology, Dioscorides, Portland, pp. 46-72.

Weir, B.S. 1990. Generic Data Analysis, Sinauer Associates, Sunderland.

Westman, W.E. 1968. Invasion of fir forest by sugar maple in Itasca Park, Minnesota. Bullerin of the Torrey Botanical Club, 95, 172-186.

Wilcove. D.S. 1987. From fragmentation to extinction. Narural Areas Journal, 7, 23-29.

Wright, S. 1965. The interpretation of pop:slation structure by F-statistics with special regard to systems of mating. Ew/urion, 19, 395-420.

Wright, S. 1978. Etwlunion and the Generics of Populations, Vol.4. Variabiliny Wirhin and Among Nurural Populations. University of Chicago Press, Chicago.

Xie, C.Y. and Knowles, P. 1991. Spatial genetic structure within natural populations of jack pine (Pinus banksiana). Canadian Journal of Bosany, 69, 547-551.

Yazdani, R., Muona, O. Rudin, D. and Szmidt, A.E. 1985. Genetic structure of a Pinus sylvestris L. seed-tree stand and naturally regenerated understorey. Forest Science, 31, 430-436.

Young, A.G. 1988. The ecological significance of the edge effect in a fragmented forest landscape. MSc Thesis, University of Auckland. 

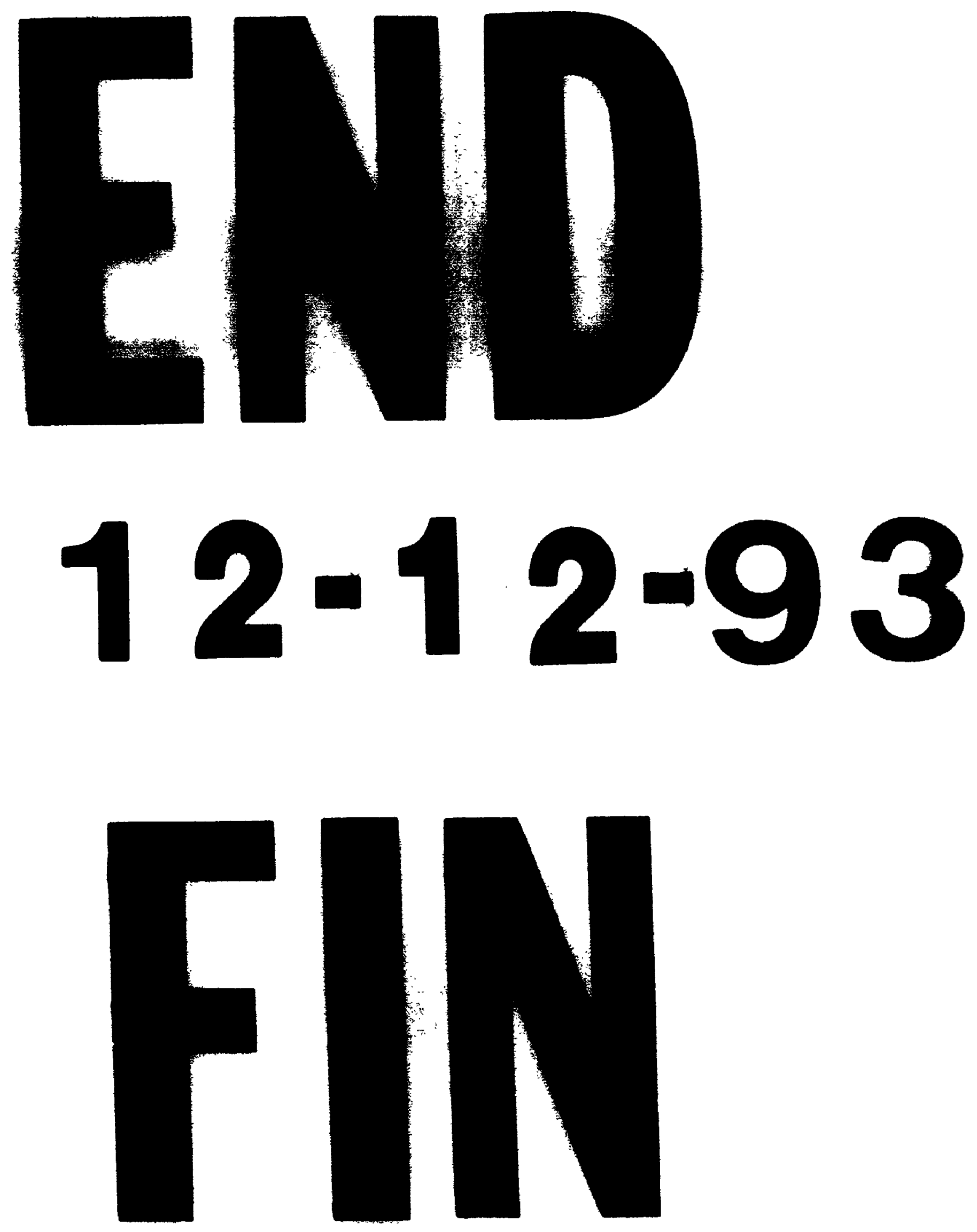